\title{
The Atlantis Bank Gabbro Massif, Southwest Indian Ridge
}

Henry J. B. Dick ${ }^{1 *} \mathbb{D}$, Astri J. S. Kvassnes ${ }^{2}$, Paul T. Robinson ${ }^{3}$, Christopher J. MacLeod ${ }^{4}$ and Hajimu Kinoshita ${ }^{3,5}$

\begin{abstract}
This paper presents the first detailed geologic map of in situ lower ocean crust; the product of six surveys of Atlantis Bank on the SW Indian Ridge. This combined with major and trace element compositions of primary magmatic phases in 99 seafloor gabbros shows there are both significant vertical and ridge-parallel variations in crustal composition and thickness, but a continuity of the basic stratigraphy parallel to spreading. This stratigraphy is not that of magmatic sedimentation in a large crustal magma chamber. Instead, it is the product of dynamic accretion where the lower crust formed by episodic intrusion, large-scale upward migration of interstitial melt due to crystal mush compaction, and continuous tectonic extension accompanied by hyper- and sub-solidus, crystal-plastic deformation. Five crossings of the gabbro-peridotite contact along the transform wall show that massive mantle peridotite is intruded by cumulate residues of moderately to highly evolved magmas, few of which could be even close to equilibrium with a primary mantle magma. This contact then does not represent the crust-mantle boundary as envisaged in the ophiolite analog for ocean crust. The residues of the magmas parental to the shallow crust must also lie beneath the center of the complex. This, and the nearly complete absence of dunites in peridotites from the transform wall, shows that melt transport through the shallow lithosphere was largely restricted to the central region of the paleo-ridge segment.

There is almost no evidence for a melt lens or high-level storage of primitive melt in the upper $1500 \mathrm{~m}$ of Atlantis Bank. Thus, the composition of associated mid-ocean ridge basalt appears largely controlled by fractional crystallization of primitive cumulates at depth, near or at the base of the crust, modified somewhat by melt-rock reaction during transport through the overlying cumulate pile to the seafloor.

Inliers of the dike-gabbro transition show that the uppermost gabbros crystallized at depth and were then emplaced upward, as they cooled, into the zone of diking. ODP and IODP drilling along the center of the gabbro massif also found few primitive gabbros that could have been in equilibrium with the original overlying lavas. Evidence of largescale upward, permeable transport of interstitial melt through the gabbros is ubiquitous. Thus, post-cumulus processes, including extensive reaction, dissolution, and re-precipitation within the cumulate pile have obscured nearly all evidence of earlier primitive origins. We suggest that many of the gabbros may have started as primitive cumulates but were hybridized and transformed by later, migrating melts to evolved compositions, even as they ascended to higher levels, while new primitive cumulates were emplaced near the base of the crust. Mass balance for a likely parental melt intruded from the mantle to form the crust, however, requires that such primitive cumulates must exist at depth beneath Atlantis Bank at the center of the magmatic complex.

The Atlantis Bank Gabbro Massif accreted by direct magma intrusion into the lower crust, followed by upward diapiric flow, first as a crystal mush, then by solid-state, crystal-plastic deformation, and finally by detachment faulting to the sea floor. The strongly asymmetric spreading to the south, parallel to the transform, was due to fault capture, with the bounding faults on the northern rift valley wall cut off by the detachment fault, which extended across the zone of intrusion causing rapid migration of the plate boundary to the north.
\end{abstract}

\footnotetext{
*Correspondence: hdick@whoi.edu

'Woods Hole Oceanographic Institution, 266 Woods Hole Road, Woods Hole,

Falmouth, MA 02543-1050, USA

Full list of author information is available at the end of the article
} 


\section{Introduction}

Until the discovery of oceanic core complexes exposing enormous outcrops of gabbro on the seafloor (Fig. 1), little was known, but much was inferred, about the nature of the lower ocean crust at slow-spreading ridges. Study of these complexes has shown that the ocean crust at slow and ultraslow ridges does not have a uniform, layer-cake structure of pillow lavas and sheeted dikes (upper crust), and gabbros (lower crust) (e.g., Conference Participants 1972)-rather, it is highly variable in thickness, composition, and architecture and even absent over large regions of the oceans (Cannat and Casey 1995; Dick 1989; Dick et al. 2003; Dick et al. 2006; Dick et al. 2008; Mendel et al. 1997; Sauter et al. 2013; Smith et al. 2014; Whitehead Jr et al. 1984). Atlantis Bank in the rift mountains of the Southwest Indian Ridge (SWIR) (Fig. 2) represents the magmatic end member of lower crust exposed in ocean core complexes. As a result, it has been a focus for research and deep crustal drilling since its discovery in 1986 (Dick et al. 1991a; Dick et al. 2000; Dick 1991), leading up to a plan to drill there through the lower crust to Moho (Project SloMo, Dick et al. 2015; Dick et al. 2016; MacLeod et al. 2017a). There are three drill sites on its crest (Fig. 3): $1508 \mathrm{~m}$ deep Hole $735 \mathrm{~B}$ at $32.7^{\circ}$ S, $57.3^{\circ}$ E; 158 m-deep Hole $1105 \mathrm{~A} 1.2 \mathrm{~km}$ to the east-northeast; and $809.4 \mathrm{~m}$-deep Hole U1473, $2.2 \mathrm{~km}$ to the north-northeast of Hole 735B. These three holes provide a unique view of the lateral variability of the Atlantis Bank Gabbro Massif spanning $\sim 200 \mathrm{kyr}$ of crustal accretion. Here, we extend this view $13 \mathrm{~km}$ to the north, $21 \mathrm{~km}$ to the south, $7 \mathrm{~km}$ to the east, and $10 \mathrm{~km}$ to the west of the drill sites to include nearly the entire $660 \mathrm{~km}^{2}$ gabbro massif, providing a three-dimensional view extending over 2 myr of crustal accretion in space and time at the paleo-ridge.

We find that the lower crust exposed at Atlantis Bank was emplaced on a long-lived detachment fault that rooted through the zone of diking at the ridge directly into a crystal mush zone. This fault extended beneath the axis of the rift valley, rooting to its north, resulting in fault capture and strong asymmetric spreading to the south, parallel to the transform.

The lower crust at Atlantis Bank is compositionally zoned, both laterally and vertically, to evolved gabbro, which intruded laterally into massive mantle peridotite now exposed along the transform wall. From this, we infer that it was fed by focused flow of melt from the mantle towards the center of the ancient ridge segment and that the primitive gabbros and dunite needed to mass balance the $1.5 \mathrm{~km}$ of gabbro drilled to date, and a similar thickness of dikes and lavas back to a mantle melt, must lie at depth at the center of the paleo-ridge segment. There is little evidence that primitive melts were stored in the upper $1.5 \mathrm{~km}$ of the lower crust, and the lavas and dikes were thus erupted directly through this sequence to the seafloor.

Core complexes form by detachment faulting at ocean ridges (for reviews, see Platt et al. 2015; Whitney et al. 2013), where the lower crust and mantle are continuously extruded on a plutonic growth fault from beneath the volcanic crust for up to several million years, while the overlying volcanic carapace of dikes and lavas spreads slowly in the opposite direction (Cann et al. 1997; Dick et al. 1981; Tucholke and Lin 1994) (Fig. 1). They range from small massifs exposed on the footwalls of detachment faults, representing a few hundred thousand years of accretion, to great domed massifs emplaced on a single fault for up to

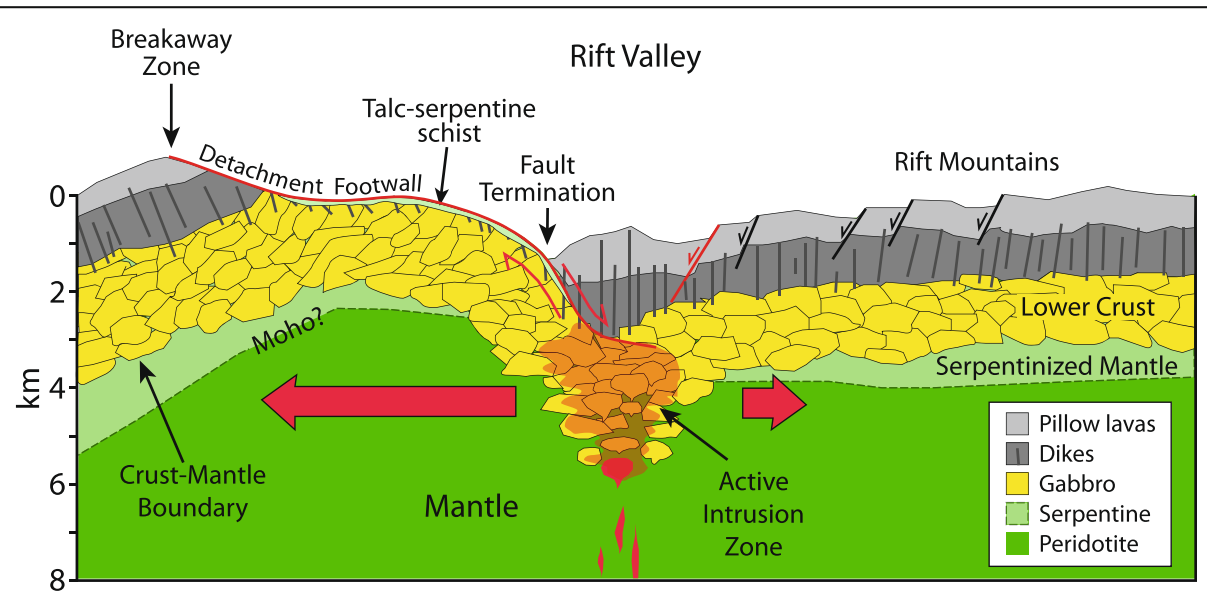

Fig. 1 Cartoon showing formation of an oceanic core complex on a non-conservative "plutonic growth fault," also known as an oceanic detachment fault. Red arrows show spreading asymmetry similar to that documented at Atlantis Bank due to fault capture causing the majority of newly accreted crust to spread to the left in the figure. Talc-serpentine schist ( $1 \mathrm{~m}$ thick) is exaggerated for graphical purposes and is shown intruding along the active detachment fault between the upper crust and the gabbro laterally from where it crosses into mantle peridotite near the transform or a ridge discontinuity 


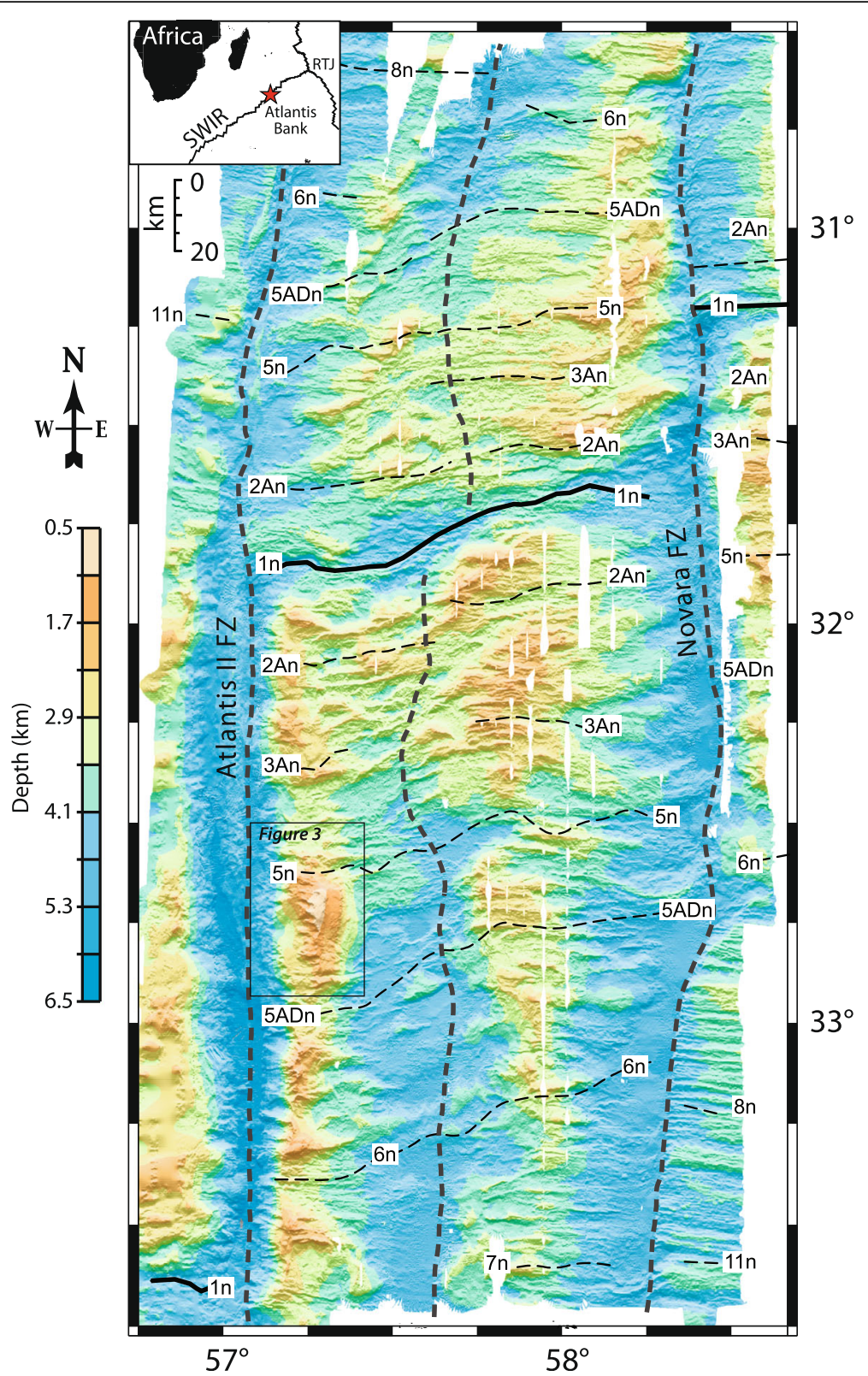

Fig. 2 SWIR shaded relief map for $56^{\circ} 45^{\prime} E$ to $59^{\circ} \mathrm{E}$ overlain by the Atlantis Bank geologic map. The east-west dashed lines indicate magnetic anomaly picks with the central anomaly $(1 \mathrm{n})$ indicated by the solid line. The north-south lines delineate the segmentation pattern and fracture zone locations (modified from Baines et al. 2007). JAMSTEC bathymetry compiled by (Hosford et al. 2003). Inset shows the SW Indian Ridge and the Rodriguez Triple Junction (RTJ)

several million years. Escartin et al. (2008) and Smith et al. (2008) have shown that this asymmetric spreading style may accommodate up to half of all seafloor spreading at slowspreading ocean ridges. Detachment faulting exposes plutonic sections ranging from mantle peridotite in regions where the crust is thin, or even missing, to enormous complexes representing the continuous extrusion of lower crustal gabbros for several million years. Modeling indicates that core complexes form when magmatic processes accommodate $30-50 \%$ of extension, while tectonic processes accommodate the rest (Tucholke et al. 2008). At greater extents of magmatic accretion, tectonic extension is accommodated by symmetric normal faulting and ductile deformation in the lower crust, with the basaltic carapace splitting in the rift valley, and migrating with an intact section of the lower crust in both directions.

The gabbroic lower crust is formed from the same basaltic melts that are parental to the upper crust. In addition to establishing the nature of the lower ocean crust, major and trace element analyses of these rocks 


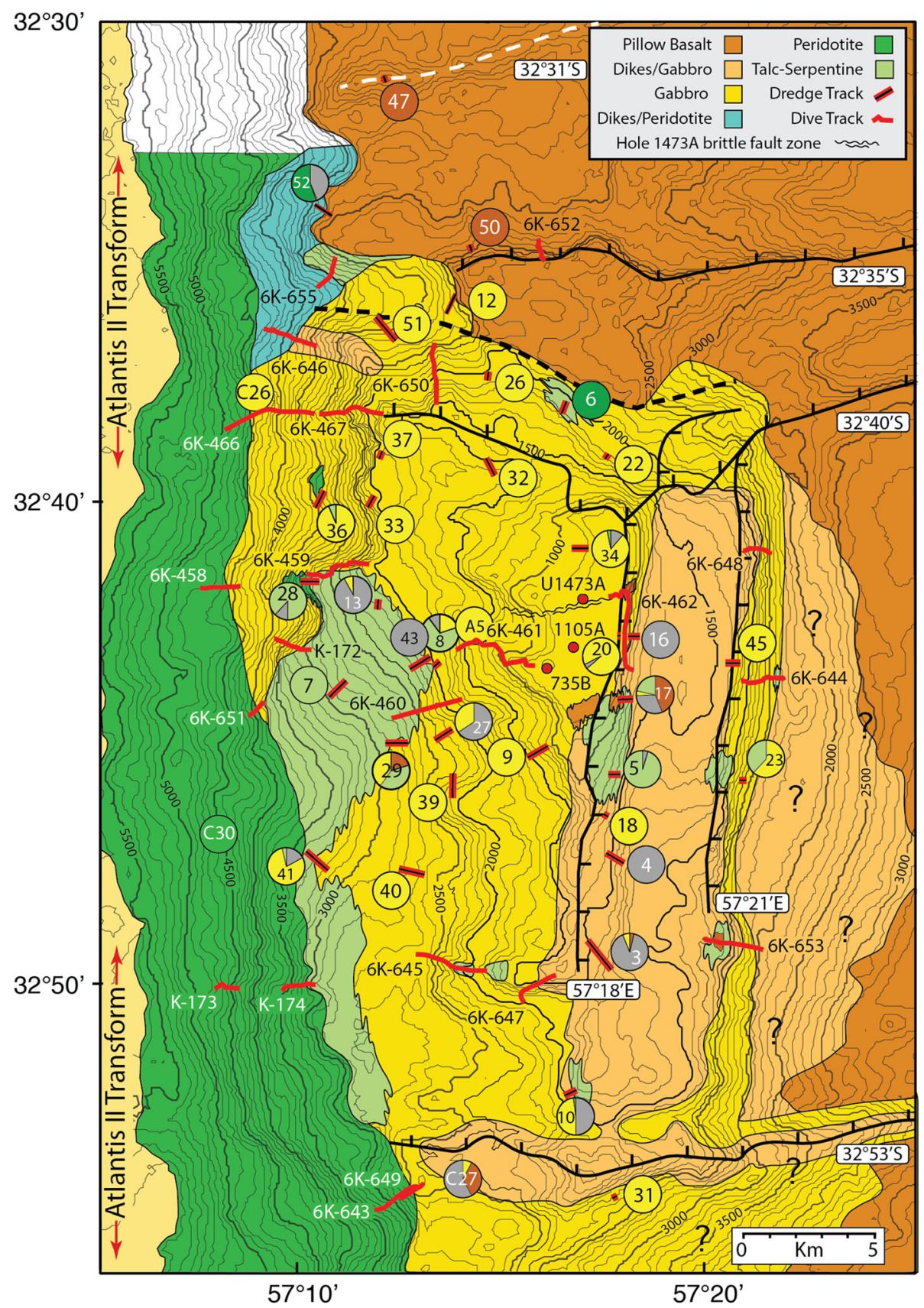

Fig. 3 Geologic Map of Atlantis Bank. Dive tracks are shown in solid red lines for the ROV Kaiko (K) and the Submersible Shinkai 6500. James Clark Ross Cruise 31 dredge tracks are shown by solid red lines with a central black line with rock proportions shown by adjacent pie diagrams without a letter prefix. Dashed white line shows location of old axial volcanic ridge. Dashed black line indicates the secondary detachment fault termination. The pillow lavas to the north cover the primary detachment fault termination. Locations of ODP Holes 735B and 1105A, and IODP U1473A are shown by red dots. Pie diagrams with letter prefixes mark starting dredge location. C stands for RV Conrad Cruise 27, Leg 9, and A stands for RV Atlantis II Cruise 9

can be used to interpret the origin and evolution of midocean ridge basalt (MORB). Here, we document the exposures of lower ocean crust in and around Atlantis Bank and construct the first three-dimensional view of a large segment-scale magmatic complex at a slow-spreading ocean ridge and its emplacement to the seafloor. We combine this with the results of major and trace element mineral analysis of gabbros collected over the bank to document both the internal processes by which it formed, and the relationship of the gabbros to the magmas that once overlay it. 
Overall, our results, consistent with the findings from previous ODP and IODP drilling (Dick et al. 2017; Dick et al. 1991a; Dick et al. 1999; Dick et al. 2000; MacLeod et al. 2017a; Robinson et al. 1989), show that the Atlantis Bank Gabbro Massif formed by episodic intrusion of relatively small gabbro bodies accompanied by continuous extension. This resulted in large-scale compaction and upward migration of interstitial melt as individual intrusions successively crystallized and migrated upward by crystal-plastic flow and faulting. Gabbros along the flank of the complex, however, are all fractionated, even those in contact with the mantle; representing downaxis, ridge-parallel intrusion of relatively fractionated melts from a centrally fed magmatic complex. The results presented here extend the conclusions derived from Hole U1473A that there is a continuum of magmatic and tectonic processes of accretion that produced a uniform magmatic-tectonic stratigraphic succession parallel to the spreading direction (Dick et al. 2017; MacLeod et al. 2017a) from $\sim 200 \mathrm{kyr}$ between drill sites, to $\sim 2 \mathrm{myr}$.

\section{Tectonic setting}

Atlantis Bank (Dick et al. 1991b) is located $\sim 73 \mathrm{~km}$ south of the ultraslow-spreading $(\sim 14 \mathrm{~mm} /$ year $)$ SWIR where it comprises part of an enormous uplifted transverse ridge flanking the $199 \mathrm{~km}$ offset Atlantis II Transform (Fig. 2). The bank, and the gabbro massif exposed on it, is roughly centered on the western 2nd-order ridge segment adjacent to the Atlantis II Transform (Fig. 2). The original overlying carapace of pillow lavas remains intact to the east where it is expressed as a series of east-west-oriented faulted ridges that overlap the core complex (Baines et al. 2007; Baines et al. 2003; Dick 1991; Hosford et al. 2003). The bank was up-faulted from beneath the sheeted dikes and pillow lavas at the eastern paleo-inside-corner high on a single, now extinct, plutonic growth fault with a $38.9 \mathrm{~km}$ heave, as in Fig. 1. Seafloor magnetic anomalies hosted within the gabbro massif show that it was extruded onto the seafloor for over $2.7 \mathrm{myr}$, beginning at circa $13 \mathrm{Ma}$ (Baines et al. 2008). During emplacement of Atlantis Bank, the paleo-SWIR spread asymmetrically to the south at rates varying between different magnetic anomaly picks (8.5 $\mathrm{mm} /$ year (Hosford et al. 2003), $10 \mathrm{~mm} /$ year (Dick 1991), and $14.1 \mathrm{~mm} /$ year (Baines et al. 2008)). We use Baines rates of $9.8 \mathrm{~mm} /$ year to the south and $4.9 \mathrm{~mm} /$ year to the north for the spreading rate calculations during emplacement of Atlantis Bank.

\section{Methods}

\section{Map compilation}

The definition of contacts between the gabbro massif and the mantle was either done by direct observation in situ, as for Dives 643 and 649, or by inference from sampling outcrops or from float or talus. Although the latter procedure is normal in field geology, the use of float and talus might seem controversial on the seafloor. In general, however, where our dredging recovered only peridotite or gabbro, actual sampling in nearby outcrop by submersible or ROV showed that the location of the contact was not confirmed. However, when gabbro and peridotite were sampled together, it invariably proved that the dredge sampled from one massive lithology to the other across a major boundary. Thus, while its spatial resolution is limited to the length of a dredge haul $(200-500 \mathrm{~m})$, the sampling proved to be a satisfactory mapping tool at the scale of our geologic investigation (Fig. 3). A complete catalog of the dredge and dive locations and their description are included in Additional files 1, 2, 3, and 4.

One might expect that downslope transport during mass wasting would mix lithologies, making this approach invalid. However, submarine mass wasting does not generally produce mixed lithologies on transform valley walls due to their steep slopes. Instead, peridotite dredges are commonly recovered at depth, whereas massive gabbros are often encountered high up on the wall with little evidence of downslope mixing (e.g., Bonatti et al. 2003; Engel and Fisher 1975; Engel and Fisher 1969). Thus, talus sampled on transform walls is generally locally derived because any large slump with the potential for significant downslope transport creates a turbidite flow that typically remains in erosional, rather than depositional, mode until it spreads out across the transform floor creating flat-lying deposits. Such turbidites were drilled during ODP Leg 118 at Site 732 uplifted on the median tectonic ridge in the middle of the transform valley. These, and dredges in the same area, recovered polymict sands, gravels, and cobbles consisting of gabbro, peridotite, diabase, basalt, and greenstone-including a short section of layered turbidite and lithic sandstone (Dick 1991; Shipboard Scientific Party, 1998).

\section{Geologic cross-sections}

Much of the interpretation of the Atlantis Bank geology depends on the cross-sections drawn from the Shinkai 6500 submersible and Kaiko ROV dives. These interpretations are based on the character of the slope (detachment fault footwall, hanging wall, normal fault face, land slip headwall, debris field) and the microstructure and igneous and metamorphic petrology of the samples. In addition, all sections are drawn as though outcrop extended to the seafloor. This is not the case, however, as much of the terrain traversed consists of sediment, sedimented rubble, and talus slopes.

These are also not straight azimuthal sections, but rather they record depth and distance along track, so 
each is accompanied by the dive track shown on the bathymetry with sample locations to interpret the area's geomorphology, and distortion relative to a true azimuthal section.

\section{Standard error}

Throughout the text and tables when an error is quoted $( \pm)$, it represents one standard deviation about the mean.

\section{Rock description}

Excluding bioclastic limestone and an abundance of seafloor flora and fauna (Additional file 1: Table S1d), rocks were cut and described, providing a full representation of the seafloor sampling over Atlantis Bank. In many cases, these came from polymict breccias, and many individual samples contain more than one rock type, including those with dike-dike, and gabbro-dike contacts, peridotites with gabbro or wehrlite veins, and plagiogranite veins (quartz diorite, diorite, trondhjemite, felsic veins) in evolved gabbros.

Lithologies were described on board ship using a modified IUGS classification scheme, and many were further redescribed ashore, showing that the initial hand specimen descriptions by a large and diverse group of scientists were not infrequently misleading. The rock names generally follow ODP and IODP conventions (see the Igneous Petrology section of the Methods chapter in Macleod et al. (2017b). Although these names are used specifically in places throughout the text, we generally refer to (a) "oxide gabbro," which includes a wide variety of differentiated, evolved gabbro types ranging from disseminated oxide (1-2\% Fe-Ti oxides), oxide gabbro ( $2-5 \%$ oxides) to oxide-rich ( $5-50 \%$ oxides); some olivine bearing, some not, some orthopyroxene bearing, some not and (b) more primitive olivine-bearing gabbros with $<1 \%$ oxide, commonly with trace amounts of intergranular hypersthene $(<0.5 \%)$. Gabbro, sensu-stricto is generally lumped with olivine gabbro, because there is a continuum between these two rock types down to $0 \%$ olivine. Dredge and dive sample locations, dredge summaries, and sample descriptions are given in Additional file 1: Table S1a, b, c, and d. We note that many samples were checked using petrographic thin sections and these are identified by having bold type in the description table. Reviewed and modified sample descriptions using highresolution images are indicated in blue type, where unmodified shipboard descriptions are in black type.

Orthopyroxene appears in two separate gabbro habits; as subhedral to euhedral stubby laths, representing a primary liquidus phase, and as intergranular rims, commonly with brown amphibole, around olivine, representing late-stage crystallization of intergranular melt. Rocks described as gabbronorites are distinguished by having orthopyroxene laths. We note that using thin sections to describe gabbronorites significantly decreased the number of such samples originally identified in the shipboard descriptions, testifying to the difficulty in distinguishing this phase in hand specimen. This also likely applies to the quoted abundance of gabbronorite in the upper $500 \mathrm{~m}$ of Hole $735 \mathrm{~B}$ hand sample descriptions.

High-temperature crystal-plastic (C-P) deformation was graded from 0 (not visible in hand specimen) to 1 (deformation evident, but lacking any well-developed foliation and having abundant relict igneous textures), 2 (clearly foliated, little primary igneous texture preserved), 3 (no igneous fabric, strongly foliated, generally medium grained (protomylonite)), 4 (strongly laminated, most primary minerals recrystallized to fine-grained neoblasts, the rest are porphyroclasts (mylonite)), 5 (ultramylonitic, some porphyroclasts, but grain-size reduction to the point where there is no visible foliation-easily mistaken for fine-grained basalt).

Brittle deformation was graded from 1 (numerous cracks with no clear movement), 2 (cracks with clear movement), 3 (clast rotation with $<50 \%$ matrix), 4 (up to $70 \%$ matrix), and 5 (>70\% matrix). Grades 3 and 4 roughly correspond to protocataclasite and mesocataclasite, whereas grade 5 includes both meso- (70-90\% matrix) and ultra-cataclasites ( $>90 \%$ matrix).

More detail on the definition and use of crystal-plastic and brittle deformation scales can be found in the Methods section of the Expedition 360 proceedings volume (MacLeod et al. 2017c).

\section{Major and trace element mineral analysis}

A representative suite of gabbros was selected for mineral analysis from the seafloor sample suite with preserved igneous augite and plagioclase $( \pm$ olivine and orthopyroxene). These included seven oriented BR cores and 10 non-oriented BGS cores, and samples from dredges JR31-3, -9, -12, -39, -40, and -41 , and Shinkai 6500 Dives 6K-459, 6K-460, 6K-466, 6K-467, and 6K-643, $-645,-646,-647,-649,-650$, and -653 (Additional file 2: Table S2). These were selected on the basis of degree of alteration, number of fresh samples in each dredge or dive suite, and sample density in a given area. Some samples have heavily saussuritized plagioclase and Cpx (clinopyroxene) altered to green amphibole, indicating greenschist and amphibolite facies alteration. These samples were therefore generally not used for mineral analysis. Olivine was typically altered to clay, serpentine, and chlorite, and only pseudomorphs were present in many of our samples. Orthopyroxene, also highly susceptible to low-grade alteration, was poorly preserved, but some, small relic cores were found for analysis.

Atlantis Bank was divided into four study areas (Fig. 4). The northern area includes JR31-12, 6K-466/467, 6K646, and 6K-650. The western area includes JR31-9, and 


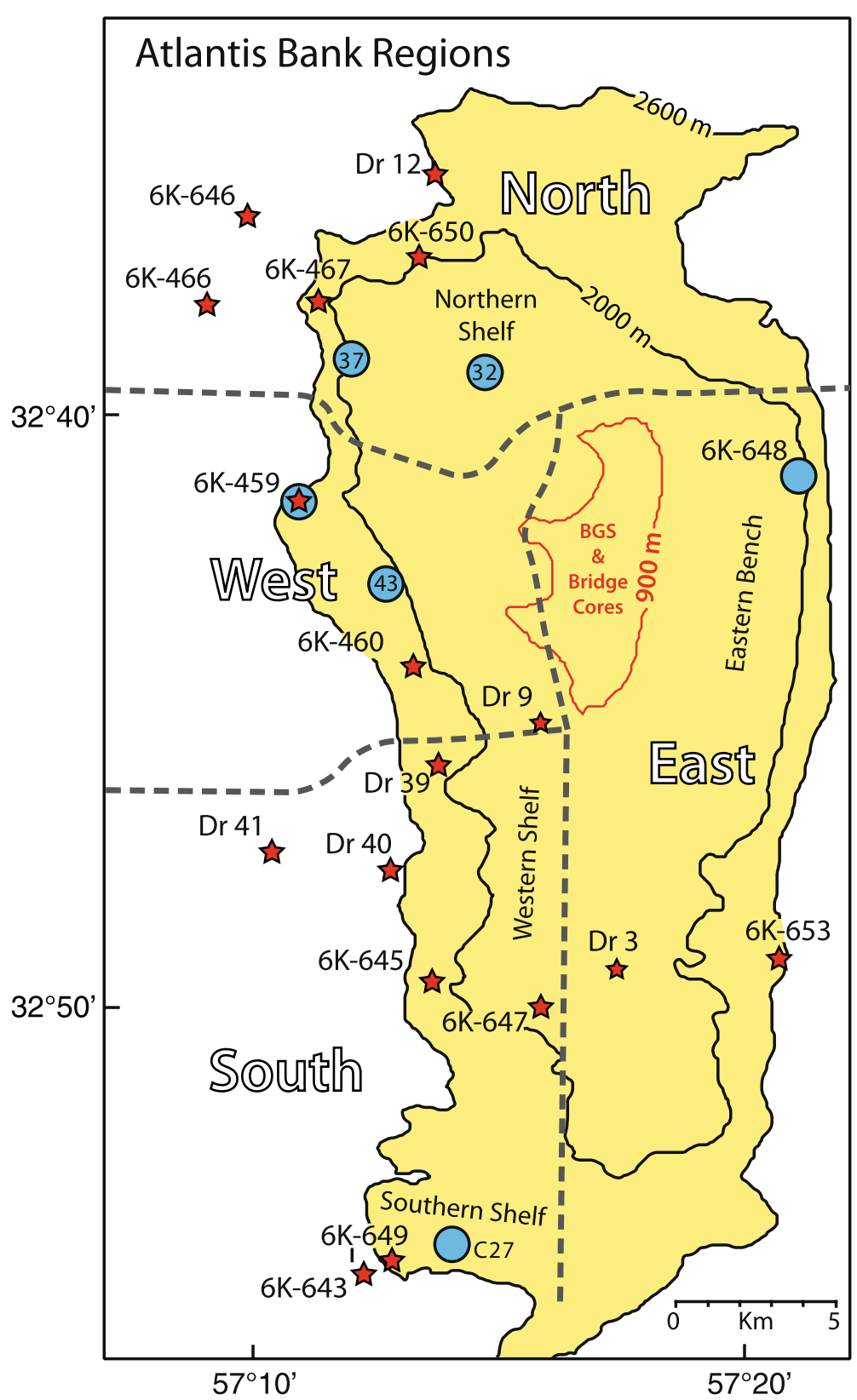

Fig. 4 Regional geographical and mineralogical divisions of Atlantis Bank. Dashed gray lines divide the northern, eastern, southern, and western regions as discussed in the text. Locations of samples selected for mineral analysis shown as red stars. Blue circles show location of oolitic limestones. Two-thousand-five-hundred-meter contour outlines the likely depth for sub-aerial erosion and shelf formation based on oolitic limestones sampled by dredging and diving. Two-thousand-meter contour shown for reference, whereas $900 \mathrm{~m}$ contour (in red) outlines the wave-cut platform at the crest of Atlantis Bank (see Fig. 5)

$6 \mathrm{~K}-459$ and $6 \mathrm{~K}-460$, whereas the southern area consists of JR31-3, -39, -40, and -41 and $6 \mathrm{~K}-643,-645,-647$, -649 , and -653 . Samples from the eastern area include the BGS and BR cores from the wave-cut platform, Shinkai Dive 653, and JCR32 Dredge 3 (Fig. 5). Augite trace- and rare-earth elements were also analyzed in eight gabbros. The sample set includes the entire macroscopic range of gabbros identified from Atlantis Bank, from very primitive troctolites in Hole $735 \mathrm{~B}$ to ferrogabbros recovered along the side of the platform, and one coarser-grained, plagioclase-Cpx-phyric diabase dike from the northern wall (6K-467-11).

Olivine (Ol), clinopyroxene (Cpx), orthopyroxene (Opx), and plagioclase $(\mathrm{Pl})$ were analyzed with the MIT 4- and 5spectrometer JEOL 733 Superprobes, using a $10 \mathrm{nA}$ beam current, $15 \mathrm{kV}$ acceleration potential, and a $10 \mu \mathrm{m}$ beam 


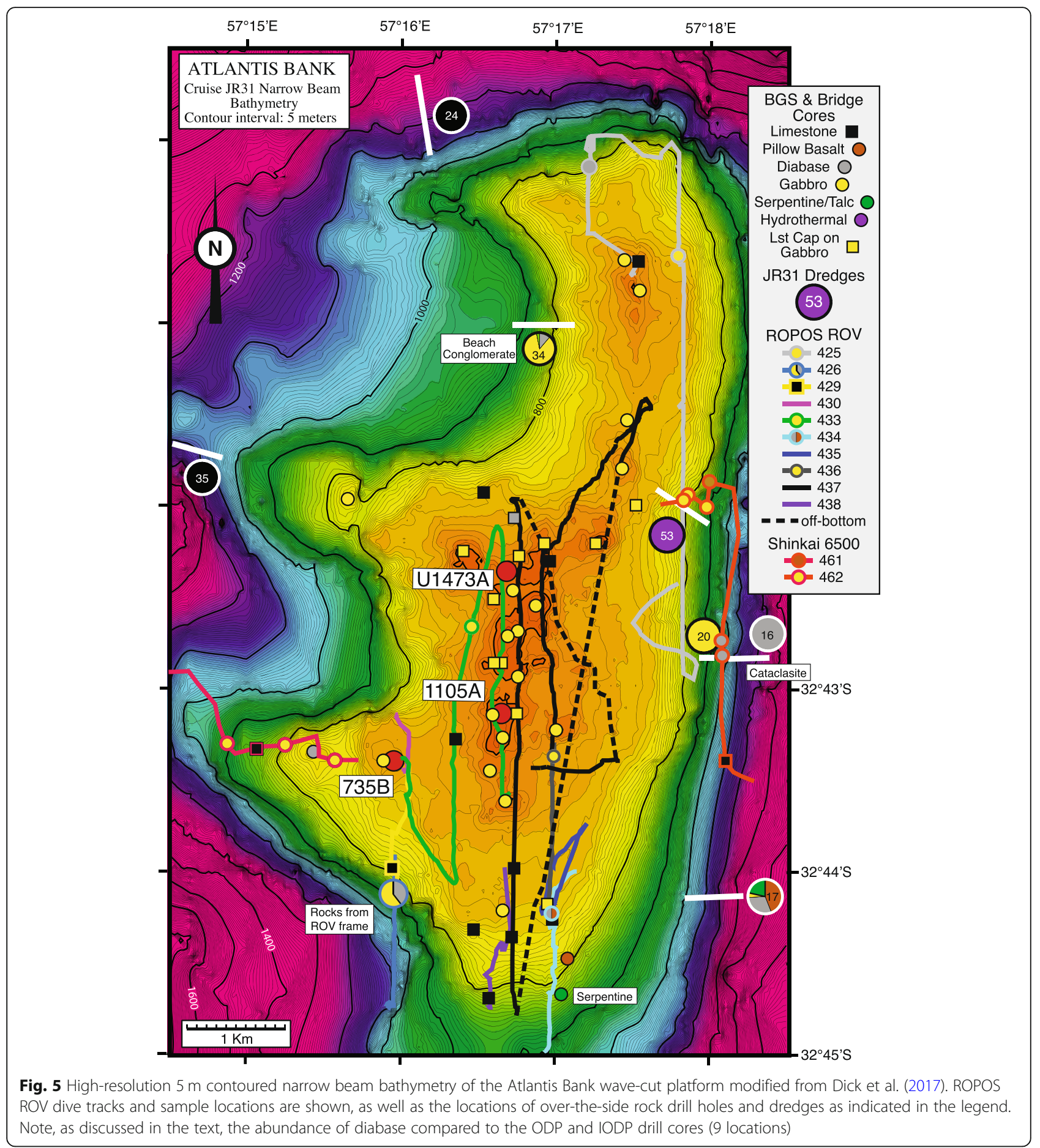

diameter. When possible, continuous $10 \mu \mathrm{m}, 10$-spot traverses in the core and the rim of adjacent mineral grains of plagioclase and Cpx were analyzed. Continuous $10 \mu \mathrm{m} \mathrm{6-}$ spot traverses in the core and rim of Opx were analyzed, whereas olivine was analyzed at six spots spaced throughout the crystal. Counting times were 10-40 s, depending on the elements. Standards used were DJ35, Marjalotti
Olivine, Synthetic Fayalite, Alp7 Opx, and Lake County Labradorite; the major elements have a standard deviation of less than 2\%. Data were reduced with the CITZAF correction package using the atomic number correction of (Duncumb and Reed 1968), the absorption coefficients of Heinrich and the fluorescence correction of Armstrong (1995). The samples analyzed and the results of the 
mineral analyses from this study are listed in Additional file 2: Table S2 and Additional file 3: Table S3.

Unaltered cores and rims of Cpx from eight samples were analyzed for trace elements on the CAMECA IMS 3f ion probe at Woods Hole Oceanographic Institution using the methods of Shimizu and Hart (1982). A primary beam of O- ions was focused to $\sim 20 \mu \mathrm{m}$ for REE (La, Ce, Nd, Sm, Eu, Dy, Er, Yb) and $\sim 10 \mu \mathrm{m}$ for other trace elements (Ti, V, Cr, Sr, Y, Zr). Energy filtering eliminated molecular interferences and a secondary voltage offset of -30 to $-60 \mathrm{~V}$ was used for the REE, and $90 \mathrm{~V}$ for the other trace elements. Uncertainties based on counting statistics were $5-10 \%$ (1s) for REE and $1-5 \%(1 \mathrm{~s})$ for the other trace elements.

In order to evaluate the chemical variability of the Atlantis Bank gabbros, we compare them to a reference model made using the MELTS algorithm of Ghiorso and Sack (1995). For this, a primary MORB melt composition was used from Kinzler and Grove (1993) that most closely matches the Hole 735B bulk composition (Dick et al. 2000) with a $\mathrm{Na}_{8.0}$ of $\sim 2.92$ and $\mathrm{Fe}_{8.0}$ of $\sim 9.2$, similar to the glasses found along the modern ridge segment to the north (Table 1). The liquid composition was calculated for isobaric, incremental batch, accumulative melting at $10 \mathrm{~kb}$ and $10.3 \%$ melting of a "depleted" spinel lherzolite modeled after that of Zindler and Hart (1986). For each fractional crystallization step of $1{ }^{\circ} \mathrm{C}$ at the QFM buffer, the compositions of the minerals and solids were determined for comparison to our analyses. The details of the modeling, and a more extensive discussion, can be found in Kvassnes (2004).

\section{Results}

\section{Geological observations}

Atlantis Bank represents an enormous uplifted northsouth-trending ridge flanking the eastern side the Atlantis II Transform. Lying along the Antarctic Convergence, it is in a region of high bottom currents, which have kept sediment cover to a minimum. On its western side, numerous landslips have exposed the basement rocks down to as much as a kilometer whereas major faults at its northern end, and on its eastern flank have provided additional large basement sections. It is capped by a 25 $\mathrm{km}^{2}$ wave-cut platform shoaling at $\sim 700 \mathrm{~m}$ depth (Fig. 5). Sub-aerial weathering pitted the many large gabbro outcrops down to $\sim 1700 \mathrm{~m}$ depth (Palmiotto et al. 2013), and oolitic sandstones were dredged down to $2500 \mathrm{~m}$ and collected by Shinkai Dive 459 at $2640 \mathrm{~m}$, $24 \mathrm{~km}$ to the north. This indicates that Atlantis Bank could have been uplifted as much as $\sim 2 \mathrm{~km}$ above sea level, assuming the deeper oolite sandstones are not sitting on down-dropped benches. Otherwise, the appearance of these sands at several locations around the bank at $\sim 2000 \mathrm{~m}$ suggests a more subdued uplift to $\sim 1.3 \mathrm{~km}$ above sea level before subsiding to its present depth. In either case, no such feature has been found flanking any major ocean fracture zone, and thus it represents a major topographic anomaly. Dick et al. (1991a) and Baines et al. (2003) have related the excess topography to an uplift produced by isostatic compensation during a spreading direction change from $\sim 010^{\circ}$ to $\sim$ due north, which happened roughly coincident with the time of detachment faulting and formation of the inside-corner high on the south wall of the paleo-ridge at its intersection with the Atlantis II Transform.

The platform was extensively surveyed with the Canadian ROV ROPOS and has a central region consisting of small sea stacks of gabbro mylonite with enclaves of undeformed gabbro. It is fringed by limestones, consisting of ripplemarked, indurated, bioclastic beach sands hosting a diverse shallow-water fauna. Extensive over-the-side rock drilling during James Clark Ross Cruise 31 Leg 2 recovered widespread crystal-plastically deformed olivine and oxide gabbros (Fig. 5) and a single crosscutting diabase dike. The fringing, lithified, bioclastic limestone beach deposit, a carbonatecemented pillow breccia, representing hanging wall debris stranded on the detachment footwall, and an ophicalcite serpentinite breccia at the southern end of the platform were also cored (Fig. 6). The carbonate fauna range from middle Miocene to Pleistocene, representing a temperate high energy environment $\sim 100-200 \mathrm{~m}$ deep. Sr isotopic ages on the carbonates give ages between 4.5 and $2.3 \mathrm{Ma}$.

Below the wave-cut platform, there are several benches on the eastern and western sides. Three of these lie above the 2000 depth contour, which include the Northern Shelf, a triangular region located roughly between Dredges 32, 33, and 37, ending near Dredge 8; the Southwest Shelf, which lies between Dredge 9 and the end of Dive 645; and the Eastern Bench, which runs nearly the full length of Atlantis Bank on the eastern side of the wave-cut platform. Additionally, there is the Southern Shelf, which lies above the $3000 \mathrm{~m}$ contour beginning at the end of Kaiko Dive 10K-174. As discussed later, the northern, southwestern, and southern shelves appear to be primarily shallow marine, erosional terraces that cut below the detachment fault footwall, and into the core of the gabbro massif around the wave-cut platform. Much of the Eastern Bench appears to

Table 1 Primary MORB composition from Kinzler and Grove (1993)

\begin{tabular}{|c|c|c|c|c|c|c|c|c|c|c|c|}
\hline$\overline{\mathrm{SiO}_{2}}$ & $\mathrm{TiO}_{2}$ & $\mathrm{Al}_{2} \mathrm{O}_{3}$ & $\mathrm{FeO}^{*}$ & $\mathrm{MgO}$ & $\mathrm{CaO}$ & $\mathrm{Na}_{2} \mathrm{O}$ & $\mathrm{K}_{2} \mathrm{O}$ & $\mathrm{H}_{2} \mathrm{O}$ & Total & Mg\# & Ca\# \\
\hline 50.3 & 0.91 & 16.4 & 7.45 & 10.9 & 11.4 & 2.52 & 0.07 & 0.05 & 100.0 & 72.3 & 71.4 \\
\hline
\end{tabular}




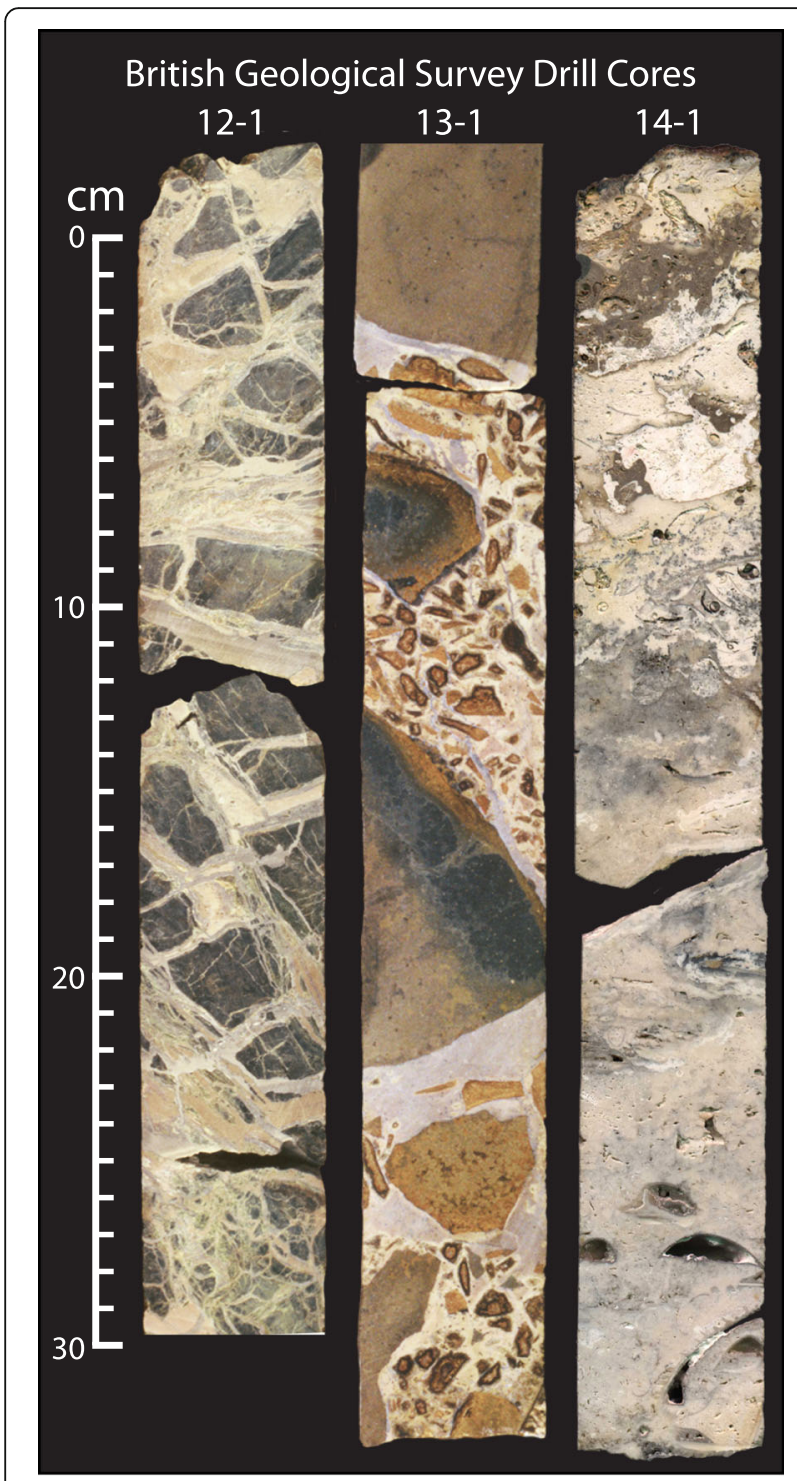

Fig. 6 British Geological Survey diamond drill cores from the Atlantis Bank wave-cut platform documenting the presence of: 12-1 carbonate veined serpentine ophicalcite in the eroded fault damage zone (JCR31 BGS 12-1 0-32 cm); -13-1 bioclastic carbonatecemented weathered pillow basalt breccia cemented clastic breccia hanging wall debris (JCR31 BGS 13-1 29-64 cm) deposited on the fault surface; 14-1 bioclastic limestone from the fringing fossil beach around the platform (JCR31 BGS 14-1 0-36 cm)

preserve a partially eroded, down-dropped portion of the original detachment fault footwall with a large domed megamullion structure running north-south along its axis.

Numerous inliers of the dike-gabbro transition are exposed across the bank, indicating that the detachment fault rooted through this boundary, and thus the massif represents a full section of the lower crust. Moho is $5.5 \pm 1 \mathrm{~km}$ close to Hole $735 \mathrm{~B}$, thinning to $4.5 \mathrm{~km}$ to the west beneath the transform (Muller et al. 1997). Our survey traced a gabbro-mantle contact along the western wall of the transform for $\sim 30 \mathrm{~km}$. The boundary lies at $\sim 4655 \mathrm{~m}$ depth in the north and shoals to $\sim 2600 \mathrm{~m}$ depth in the south (Fig. 3). This indicates that the magmatic complex expanded to the north by $\sim 6 \mathrm{~km}$ towards the transform domain with decreasing age (Dick et al. 2017). This contact has been previously used to suggest that Moho beneath the Bank is a serpentinization front. However, our synthesis finds that it is an intrusive contact between evolved gabbros and mantle peridotite now exposed along the transform wall. The gabbroperidotite contact on the transform wall $\sim 2800 \mathrm{~m}$ below the drill sites at $\sim 32^{\circ} 43^{\prime} \mathrm{S}$ then provides a minimum constraint on lower crustal thickness at the time of accretion.

The northern end of the core complex has two benches that are the product of secondary east-west-striking detachment faults that successively down dropped the primary detachment fault surface, and together comprise the termination zone for the core complex. The northern fault at $32^{\circ} 35^{\prime} \mathrm{S}$ lies largely within otherwise intact pillow lava flows that were erupted over the underlying gabbros and peridotites exposed in the headwall of a large landslip on the transform wall. The southern of the two faults, at $32^{\circ}$ $40^{\prime} \mathrm{S}$ juxtaposes the gabbro massif against the hanging wall pillow lavas that cover the intervening bench along most of its length (Fig. 3), cutting down through the gabbro-peridotite contact on the transform wall to the west.

The two north-south, high-angle normal faults on the eastern flank of the massif at $57^{\circ} 18^{\prime}$ and $57^{\circ} 21^{\prime} \mathrm{E}$ successively down dropped the detachment fault footwall forming the Eastern Bench, and a smooth, gentle half dome that terminates in intact east-west lineated volcanic terrain to the east. The half dome has not been sampled, though it likely consists of the same dikes and gabbros as on the Eastern Bench. The detachment breakaway zone to the south is morphologically inferred from apparent constructional volcanic edifices that replace the gabbro-dike terrain south of $32^{\circ} 53^{\prime} \mathrm{S}$, though this may represent an imbrication of an earlier detachment fault, whose termination lies farther to the south.

The majority of our samples were collected during James Clark Ross Cruise 31 ("JR31") Legs 1 and 2 by 41 successful dredges around the Bank, and with the BRIDGE ("BR") and British Geological Survey ("BGS") over-the-side rock drills on the wave-cut platform as well as Canadian ROV ROPOS grabs (Fig. 5), and by several dredges made on RV Conrad Cruise 27, Leg 9. These are supplemented by direct seafloor observations and a large sample suite collected during the Japan Agency for Marine-Earth Science and Technology (JAMSTEC) MODE 98, MODE 2000, and ABCDE expeditions to Atlantis Bank by the Shinkai 6500 
submersible and the ROV Kaiko. The dredging in combination with later ROV and submersible dives allows construction of a well-constrained geologic map supplemented by ODP and IODP drill cores from Holes 735B, 1105A, and U1473A.

Table 2 summarizes the seafloor sample suite. In addition, we note that 28 dredges contained only gabbro, 16 contained oxide and olivine gabbro, and 11 contained only olivine gabbro and 4 only oxide gabbro. Excluding metagabbros, $41.9 \%$ of the gabbro (by number) is olivine gabbro (gabbro, olivine gabbro, and troctolite), 44.4\% oxide gabbro (oxide gabbro, gabbronorite), and 5.3\% felsic veins. The remaining $8.9 \%$ is metagabbro, too altered to determine its variety. By comparison Hole $735 \mathrm{~B}$ penetrated $78 \%$ olivine gabbro, with $30 \%$ oxide gabbro in the upper $500 \mathrm{~m}, 12 \%$ in the lower $1000 \mathrm{~m}$, and $<1 \%$ in the lower $300 \mathrm{~m}$. On the basis of these results, it is clear that the seafloor samples have an even greater proportion of oxide gabbro than even the upper $500 \mathrm{~m}$ of Hole $735 \mathrm{~B}$, or the $143 \mathrm{~m}$-deep Hole 1105A and $809 \mathrm{~m}$-deep Hole U1473A. This is hardly surprising because Fig. 3 shows that large faults that expose deeper sections of the gabbro massif occur only in the northern region, whereas the uppermost section of the core complex, where diving found oxide gabbro most abundant, was removed by erosion.

Shown in Fig. 7 are sample statistics for the SWIR and Atlantis II Transform. Excluding the Atlantis II Transform and Atlantis Bank, gabbro constitutes only $4 \%$ of the samples in 238 SWIR dredges (Zhou and Dick 2013)_far less

Table 2 Atlantis Bank seafloor samples $(N=937)$

\begin{tabular}{|c|c|c|c|c|c|c|c|c|}
\hline Lithology & $N$ & $\%$ & C-P & 10 & Brittle & 10 & Oxide $\%$ & 10 \\
\hline Metaperidotite & 115 & 43.4 & 2.3 & 1.5 & & & & \\
\hline Plagioclase peridotite & 9 & 3.4 & 1 & 0.5 & & & & \\
\hline Lherzolite & 108 & 40.8 & 0.7 & 0.8 & & & & \\
\hline Harzburgite & 10 & 3.8 & 1 & 0.5 & & & & \\
\hline Talc-soapstone-serpentinite-tremolite schist and breccia & 23 & 8.7 & nd & nd & & & & \\
\hline Total peridotites & 265 & 28.3 & 1.4 & 1.4 & & & & \\
\hline Olivine websterite & 6 & 0.6 & 0.8 & 0.8 & & & & \\
\hline Dunite & 3 & 0.3 & nd & nd & & & & \\
\hline Troctolite & 1 & 0.2 & 0.7 & na & & & & \\
\hline Olivine gabbro & 156 & 33.9 & 1.2 & 1.2 & 1.2 & 1.4 & & \\
\hline Gabbro & 36 & 7.8 & 1.8 & 1.1 & 2.2 & 1.8 & & \\
\hline Gabbronorite & 21 & 4.6 & 1.6 & 0.7 & 0.7 & 0.4 & & \\
\hline Oxide gabbro & 183 & 39.8 & 1.8 & 1.5 & 0.8 & 1 & 6.7 & 1.5 \\
\hline Metagabbro & 41 & 8.9 & 2.3 & 1.3 & 2.3 & 1.6 & & \\
\hline Felsic vein/plagiogranite & 22 & 4.8 & 0.5 & 0.8 & 0.6 & 0.7 & & \\
\hline Total gabbros & 460 & 49.1 & & & & & & \\
\hline Aphyric diabase & 86 & 56.2 & & & & & & \\
\hline Olivine diabase & 5 & 3.3 & & & & & & \\
\hline Plagioclase-olivine diabase & 18 & 11.8 & & & & & & \\
\hline Plagioclase diabase & 44 & 28.8 & & & & & & \\
\hline Total diabase & 153 & 16.3 & 0 & 0 & 1.7 & 1.3 & & \\
\hline Aphyric basalt & 20 & 44.4 & & & & & & \\
\hline Olivine basalt & 7 & 15.6 & & & & & & \\
\hline Plagioclase-olivine basalt & 11 & 24.4 & & & & & & \\
\hline Plagioclase-olivine augite basalt & 1 & 2.2 & & & & & & \\
\hline Plagioclase basalt & 6 & 13.3 & & & & & & \\
\hline Total basalt & 45 & 4.8 & & & & & & \\
\hline Pillow basalt & 19 & & & & & & & \\
\hline Mafic mylonite/cataclasite & 3 & 0.3 & & & & & & \\
\hline Oxidized sulfide chimney & 2 & 0.2 & & & & & & \\
\hline
\end{tabular}




Stlantis Bank Local High Excluding
on Eastern Transform Wall
Fig. 7 Dredge statistics for the Southwest Indian Ridge, and the Atlantis II Transform walls. Percentages are calculated by the weight of material
recovered. Modified from Zhou and Dick (2013). The average weight of the 868 rocks weighed and described from Atlantis Bank was $3.7 \pm 5.81$
kg, with a mean weight of 1.5 kg and a range from 0.01 to 48 kg. In all, some 1123 different samples by lithology were found in the $3243 \mathrm{~kg}$ of
rock described, with numerous samples containing more than one lithology. For samples < $0.1 \mathrm{~kg}$, the weight given is nominal depending on the
size of the pebble. Similarly, with many of the larger samples, the weight was estimated as well. Table 2 percentages normalized to $100 \%$

than anticipated by the Penrose Ophiolite model. Thus, SWIR lower crust is likely thin and discontinuous, consisting of small, highly localized, magmatic centers from which basalt was erupted down-axis to produce crustal sections consisting largely of pillow lavas and dikes overlying and intruding mantle peridotite. The $\sim 660 \mathrm{~km}^{2}$ Atlantis Bank Gabbro Massif, by contrast, is the largest known outcrop of gabbroic rock in the modern oceans with extensive mantle outcrops at its base. It it is a batholith representing the most magmatically robust known oceanic core complex, and comes closest to providing a representative section of the lower ocean crust formed at slow-spreading ridges.

Excluding Atlantis Bank, gabbro remains exceptionally abundant along the eastern Atlantis II Transform wall, indicating greater than normal magmatic activity. Gabbro is 5 times as abundant as anywhere else on the SWIR. This indicates either a higher than normal mantle potential temperature or a more fertile source composition. The Gallieni Transform, for example, is similar in size and closer to the Marion Hotspot, but despite extensive sampling, little gabbro has been recovered there. Given the great distance from any mantle hotspot, and the rather typical ridge depth for the region, it seems apparent that the mantle source between the Atlantis II and Novara Transforms over the last $13+$ myr has been unusually fertile, which is consistent with the unique isotopic composition of the basalts from the modern ridge axis (Snow 1993).

\section{Igneous petrology Petrography}

The complex internal stratigraphy and petrography of the long gabbro sections drilled by ODP and IODP are well described in the ODP and IODP Leg 118, 179, and 176 Initial and Scientific Reports (Casey and Miller 1999; Casey and Miller 2007; Dick et al. 1991a; Dick et al. 1999; MacLeod et al. 2017a; Natland et al. 2002; Robinson et al. 1989). The seafloor samples examined here include the same features, and we summarize the highlights using insights gained from the reports listed above.

All of the seafloor gabbros are igneous cumulates, meaning that virtually none have the composition of a possible magma, and accordingly initially formed by crystal fractionation, and post-cumulus, melt-rock reaction. Augite and plagioclase are ubiquitous, with modal plagioclase generally exceeding augite. Olivine is less abundant and commonly occurs as anhedral intergranular grains (Fig. 8e) or rounded grains enclosed in pyroxene. In most samples, plagioclase grain size exceeds that of pyroxene, which exceeds that of olivine. Orthopyroxene occurs as late magmatic interstitial rims around olivine (Fig. 8e), and as a primary liquidus phase in the form of elongate, euhedral to subhedral laths in oxide gabbros and gabbronorites. Oxide occurrence in the seafloor gabbro suite is bimodal, as it is in the ODP and IODP drill holes. Fe-Ti oxides in oxide gabbros range from $\sim 1$ to $>50 \%$ in extreme examples, averaging about $6-7 \%$, with $1-2 \%$ disseminated oxide gabbro most common; more oxide-rich varieties decrease exponentially in abundance up to $~ 15 \%$ oxide (Additional file 1: Table S1d). Olivine gabbros, by contrast, are generally nearly oxide free.

Texturally, the gabbros are very diverse, ranging from sub-ophitic with randomly oriented plagioclase crystals in a matrix of intergranular augite and olivine, to equigranular (Fig. 8a, b). Many samples are "varitextured" with large variations in grain size, ranging from pegmatitic to fine-grained, with the individual phases varying in size together. Grain size ranges from fine- 


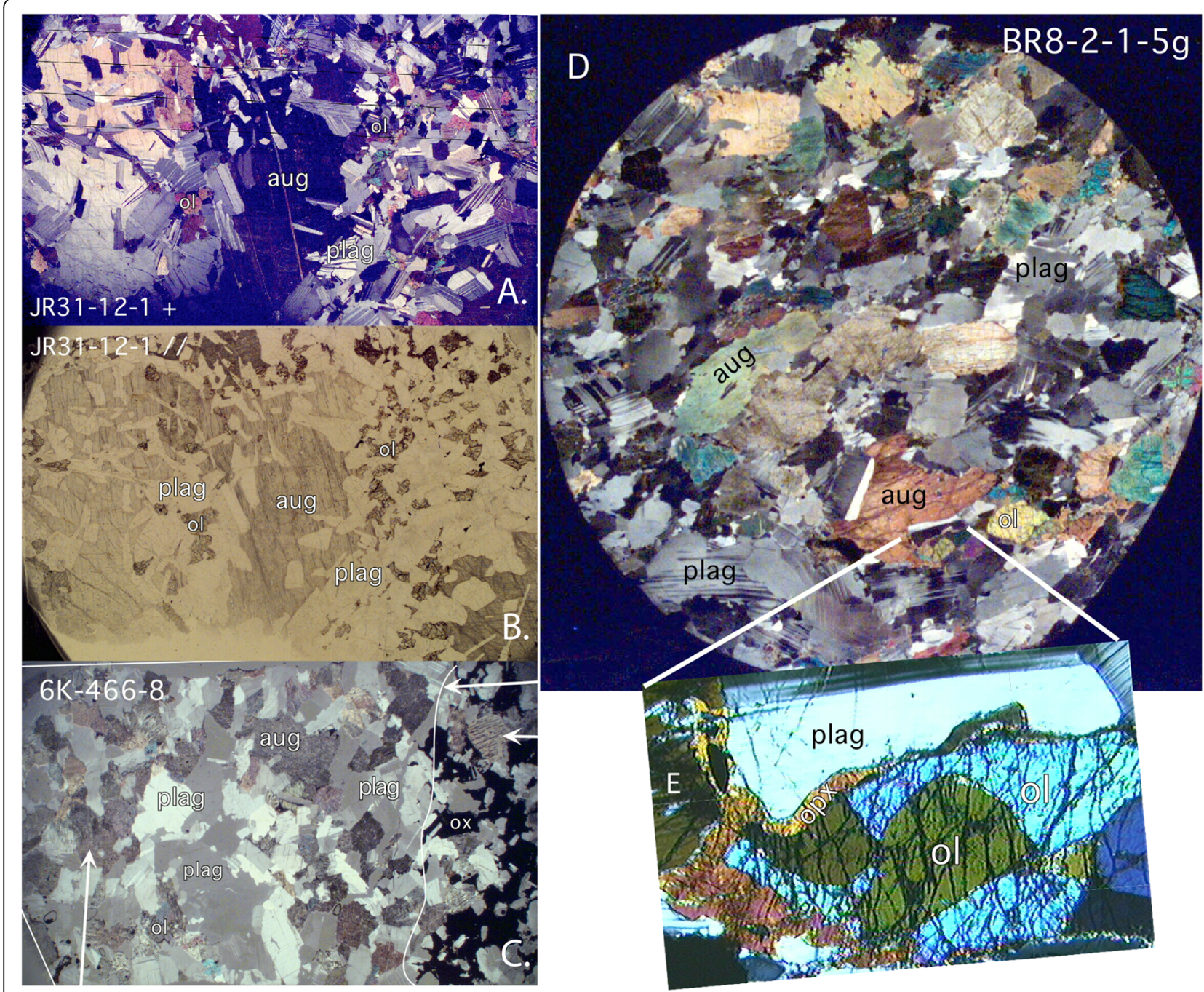

Fig. 8 Photomicrographs of various Atlantis Bank gabbros. a Sample \# JR31-12-1: Sub-ophitic augite surrounds plagioclase laths with interstitial olivine (in crossed polars). Plagioclase, plagioclase; aug, augite; ol, olivine. Field of view is $7.5 \mathrm{~cm}$ across. b Same slide in plane polarized light. c Sample 6K-466-8: Field of view is $2.5 \mathrm{~cm}$ across. The white line indicates the contact between olivine gabbronorite and oxide gabbronorite. The picture uses a combination of reflected and plain polarized light illumination to distinguish different minerals. White arrows point to the analyzed areas. d Sample BR8-2-1-5g: This sample underwent weak, high-temperature, crystal-plastic deformation, as indicated by kink-banded pyroxene and bent plagioclase crystals. Image in cross-polarized light with a field of view $2.5 \mathrm{~cm}$ across. e Detail of $\mathbf{d}$ showing an interstitial thin orthopyroxene grain between interlocking olivine and plagioclase

grained microgabbros to abundant medium- to locally very coarse-grained gabbros. Although grain size may vary irregularly at the hand specimen scale, it is typically relatively uniform in samples from a given dredge haul. Layering is common, but as in the drill cores, it generally appears to be the result of deformational stretching of irregular fine- and coarse-grained zones. Locally, zones of fine- to medium-grained gabbro crosscut coarser gabbro, generally with the appearance of anastomosing channels, presumably due to melt-rock reaction and locally focused melt flow.

Oxide gabbro, as used here, refers to a wide range of lithologies, significantly more evolved in silicate chemistry than gabbro (sensu-stricto), olivine gabbro, and troctolite. These include oxide gabbro ( $>5 \%$ oxides), oxide-bearing gabbro ( $2-5 \%$ oxides), and disseminated oxide gabbro ( $1-2 \%$ oxides), as well as varieties with olivine and/or tabular orthopyroxene, including gabbronorites. Oxides are usually interstitial to the silicates (Fig. 8c) and are commonly concentrated in narrow bands along shear zone boundaries, as a matrix around pyroxene neoblasts, and in pressure shadows adjacent to porphyroclasts of pyroxene or plagioclase. Ilmenite and magnetite occur in individual grains or as trellis-twin exsolution lamellae, most likely after ulvöspinel. Oxide gabbros occur in several different habits. Many appear 
to have formed by impregnation of olivine gabbro by late Fe-Ti-rich melts, commonly along high-temperature shear zones that crosscut olivine gabbro, producing a variety of complex relationships. Other oxide gabbros appear to exhibit little deformation and may reflect a more direct intrusive origin. Oxide-rich, coarse-grained, pegmatoidal, pyroxene-rich layers with subordinate plagioclase are also present. In Hole U1473A, these appear to represent local channels where late Fe-Ti-rich melt migrated by permeable flow through and reacted with, the enclosing olivine gabbro.

Point counting thin sections was not done, as the rocks are generally so coarse-grained that even large $(2 " \times 3$ ") thin sections do not adequately represent the mineral mode (e.g., Fig. 9a). However, Coogan et al. (2001) analyzed whole-rock compositions of the Atlantis Bank gabbros sampled during JR31, and we calculated mineral modes based on the methods in Grove et al. (1992b) and compared them to MORB from the modern ridge, the transform walls, and to the Hole 735B average composition of

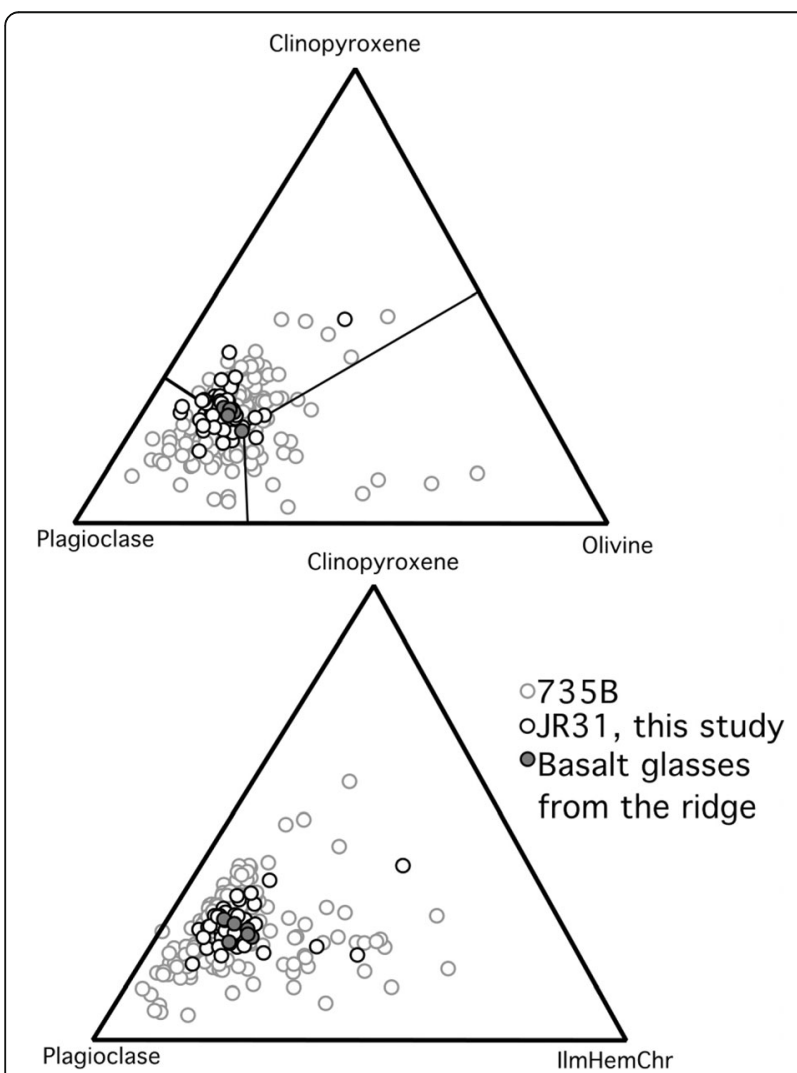

Fig. 9 Calculated mineral norms for Atlantis Bank gabbros, and average Hole 735B compositions from whole-rock data using the method of Grove et al. (1992a, 1992b). The cotectic lines in the uppermost figure represent the $1 \mathrm{~atm}$ olivine-plagioclase-augite-melt saturation boundary based on SWIR basalt glass, thus indicating that these gabbros generally do not have a simple liquid composition and are therefore cumulates. Lower panel shows plagioclaseclinopyroxene-oxide plot for reference
Dick et al. (2000). If the gabbros were formed as cumulates by simple fractional crystallization of a primitive mantlederived melt, the whole-rock compositional mineral modes should start as pure olivine cumulates (dunite), continue along the plagioclase-olivine cotectic, and end at the 4phase saturation-boundaries outlined in Fig. 9a. The wholerock compositions clearly span a much wider range than this. There are excesses in plagioclase and Cpx, suggesting mechanical separation of the minerals or reactive modification of mineral proportions after cotectic crystallization.

\section{Trace element mineral geochemistry}

Shown in Fig. 10a and given in Additional file 4: Table S4 are REE concentrations for Atlantis Bank gabbros, which were used to calculate the theoretical equilibrium liquid compositions shown in Fig. 10b. Almost all the augites have negative $\mathrm{Eu}$ anomalies, indicating that the

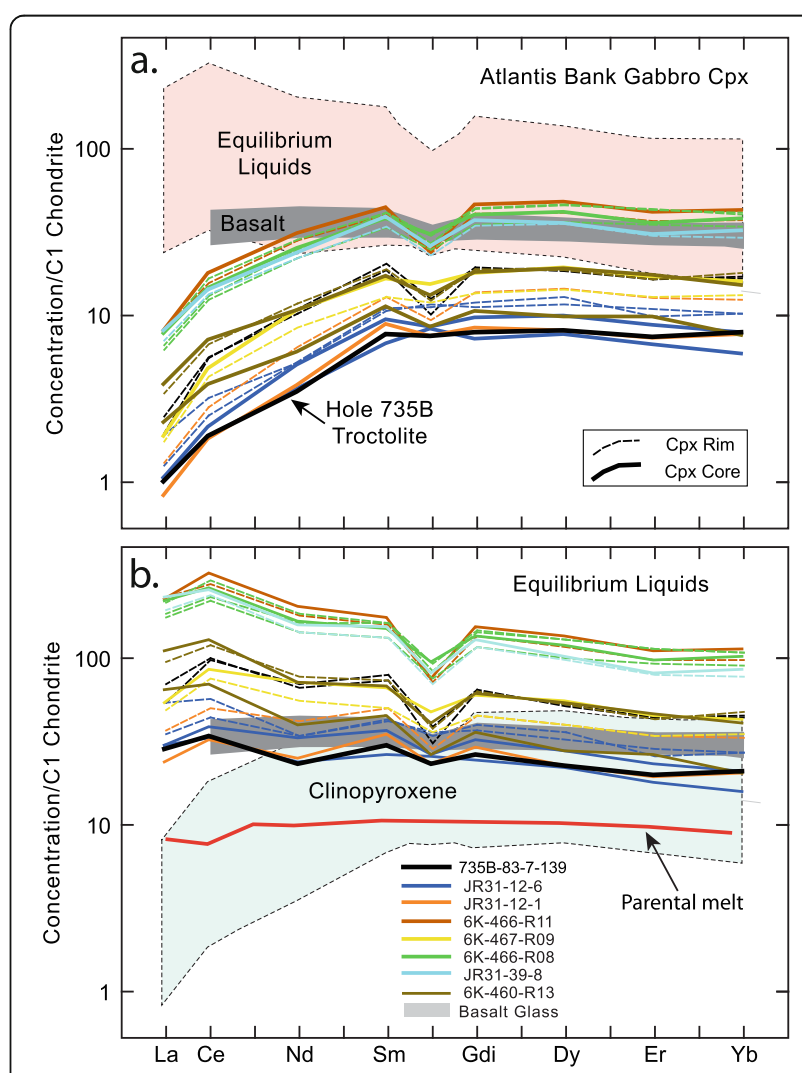

Fig. 10 a REE concentrations in gabbro augite from dredges, dives, and drilling at Atlantis Bank normalized to the $\mathrm{C} 1$ chondrite values of Anders and Grevesse (1989). Gray field for Atlantis Bank and Segment 19 (Cannat et al. 1999) SWIR basalts is from Johnson and Dick et al. (1992). Pink field for equilibrium liquids is from panel b. b Equilibrium liquids calculated using the REE partition coefficients of Sobolev and Shimizu (1992). Heavy black line is the Hole 735B troctolite from core 83-7. Blue field for Atlantis Bank augite is from panel a. Parental melt representing $5 \%$ melting of the hypothetical DMM composition of Workman and Hart (2005) is shown for comparison by the heavy red line 
augite crystallized after a substantial volume of plagioclase had fractionated from the melt. Inspection of Fig. 10a shows two main augite groups: relatively primitive gabbros, with minimal europium anomalies, and highly fractionated melts with large europium anomalies.

The primitive melts include core analyses of JR31-12-6 and JR31-12-1, and Hole 735B troctolite in Core 83-7. Their patterns are consistent with a moderately fractionated MORB similar to what has been sampled at Segment 19 at, and to the north of, Atlantis Bank. Shown for comparison is a low degree 5\% melt of Workman and Hart (2005) that could make a reasonable parental liquid for the Atlantis Bank gabbros. However, it demonstrates that none of the gabbros sampled at Atlantis Bank is even close to equilibrium with any likely parental melt. Parental melts for higher degrees of melting would have even lower REE concentrations, requiring even greater extents of fractional crystallization to explain the composition of the Segment 19 basalts and Atlantis Bank gabbros.

The rim compositions of the relatively primitive gabbro augites and the compositions of the more fractionated gabbros all show large europium anomalies, with calculated liquid compositions far more fractionated than any Segment 19 lavas. This is consistent with extensive melt-rock reaction with migrating interstitial melts that have undergone extensive modification during reactive porous flow to compositions far outside the MORB field, consistent with the petrographic and major element mineral data presented in this paper. Only sample JR31 39-8 has a composition consistent with crystallization from a Segment 19 lava.
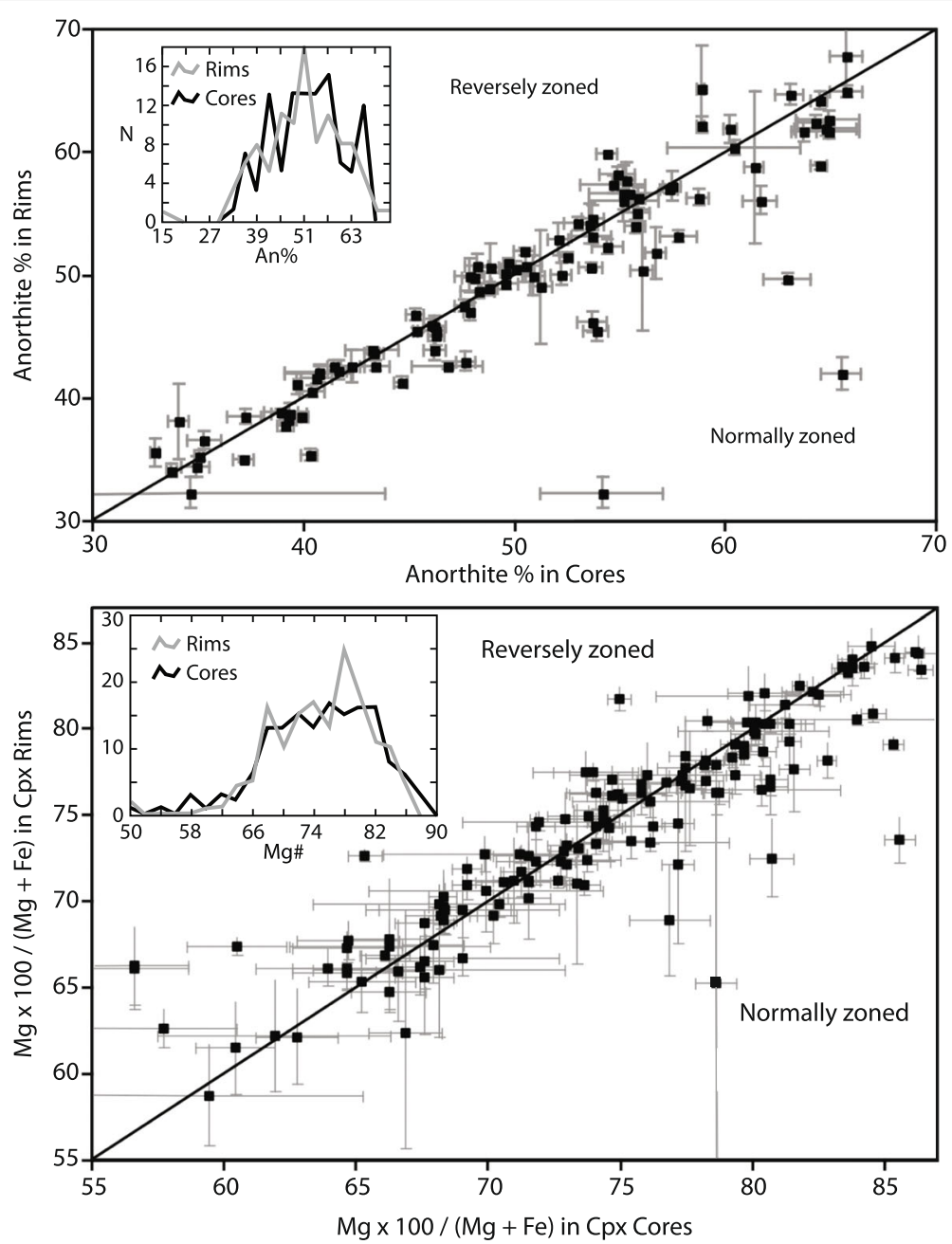

Fig. 11 a Compositions of plagioclase cores and rims from gabbros of this study plotted with the standard deviations for the analyses. Note that the distributions of core and rim analyses are nearly indistinguishable (inset plots). Line indicates 1:1 proportion. b Compositions of cores and rims of clinopyroxene from Hole 735B. The data are from Dick et al. (2001) and Angeloni and Dick (1990) (troctolite dikes from the upper $550 \mathrm{~m}$ of Hole $735 \mathrm{~B}$ ). The solid black line indicates 1:1 proportion. The core-rim information is not generally available for the upper $550 \mathrm{~m}$ of Hole $735 \mathrm{~B}$ 


\section{Plagioclase major element compositions}

The average plagioclase has $49.5 \%$ anorthite $\left(\mathrm{An}_{49.5}\right)$, and the highest in any sample is $71.5 \%$. Only a few individual plagioclase grains have anorthite contents below $\mathrm{An}_{32.3}$, and those have likely been albitized by low-temperature hydrothermal alteration. The orthoclase contents increase slightly as anorthite decreases, although it rarely exceeds $\mathrm{Or}_{1}$. Mineral zoning is common (Fig. 11a), with plagioclase reversely zoned with rims more An-rich than cores in 50 of 109 samples. The core to rim difference in anorthite content is $>1 \sigma$ in 23 of the 50 reversely zoned samples. Fifty-nine plagioclase grains are normally zoned, and the core to rim change in anorthite content is $>1 \sigma$ in 37 of the 59 normally zoned samples.

\section{Clinopyroxene composition}

Augite is the principal Cpx in the gabbros, with a broad range of equilibration temperatures for coexisting Cpx and Opx indicated in the Lindsley and Andersen (1983) pyroxene quadrilateral (Fig. 12). The samples range from Mg\# (Molar $100 \mathrm{x} \mathrm{Mg/}$ $(\mathrm{Mg}+\mathrm{Fe}))$ 48.1 to 86.3, averaging 74.5. Augite in equilibrium with a primary melt would have a $\mathrm{Mg} \#$ of 91, and none of the Atlantis Bank augites are even close to that. A single undeformed troctolite was identified in hand specimen in the seafloor sample suite (6K 648-8) and was analyzed at Leibniz University Hanover. It has augite with $\mathrm{Mg} \#$ 88-90 (Koepke, pers. com.), which would be close to equilibrium with a primary MORB.

Figure 13 shows two large augite crystals enclosing many partially resorbed plagioclase laths. The cores and rims of these $\mathrm{Cpx}$ grains show a wide range in composition with $\mathrm{Cr}_{2} \mathrm{O}_{3}\left(0.10-0.61\right.$ wt.\%) and $\mathrm{TiO}_{2}$ (0.35-0.84 wt.\%) having an intragranular compositional range comparable to the entire lower half of Hole 735B (Dick et al. 2002). The Mg The Mg\# of the augite varies from 73.6 to 86.1 , and weight percent $\mathrm{Al} 2 \mathrm{O} 3$ from 73.6 to 86.1 , whereas alumina varies from 1.86 to $3.85 \mathrm{wt} . \%$. These large, single-sample, and single-grain ranges for the minor and major elements are common throughout our suite of samples (Fig. 14b), demonstrating large-scale mineral disequilibria through most of our samples, which can be attributed to late-stage permeable flow and partial reaction with exotic melts through the cumulates.

Cores and rims were analyzed in $158 \mathrm{Cpx}$ grains (Fig. 11). On average, augite in oxide-rich gabbros is significantly more strongly zoned than in gabbro and olivine gabbro, which is also seen in Hole 735B, where the average difference between core and rim is $\mathrm{Mg} \# 2.9$ for oxide gabbros and 1.9 for gabbro and olivine gabbro in the lower kilometer. Fifty-one of our samples (32\%) have crystal zoning greater than $1 \sigma$ standard error of analysis: 24 reverse and 24 normal. Although core-rim data are not available for the upper $500 \mathrm{~m}$ of Hole 735B, Dick et al. (2002) analyzed cores and rims of 196 pyroxenes in the Leg 176 shipboard thin section suite from the lower kilometer of Hole 735B, and 154 (79\%) have zoning greater than 0.7 standard error of analysis. In contrast to our data, $129 \mathrm{Cpx}$ are normally zoned, and only 25 reversely zoned in the lower $1 \mathrm{~km}$ of Hole $735 \mathrm{~B}$ (Fig. 14), excluding differences that were less than the average error for analysis of $\mathrm{Mg \#} 0.7$.

\section{Orthopyroxene major element compositions}

Orthopyroxene commonly occurs as hypersthene and, although moderately sparse, is found in all areas of the Bank, with an intermediate range of compositions compared to Hole 735B. Orthopyroxene is susceptible to sea floor alteration, and thus fewer grains have been analyzed than in the more protected and unaltered drill-core samples from ODP Hole 735B. The compositions range from $\mathrm{Mg} \# 56$ to 78 , with an average of 67 ;

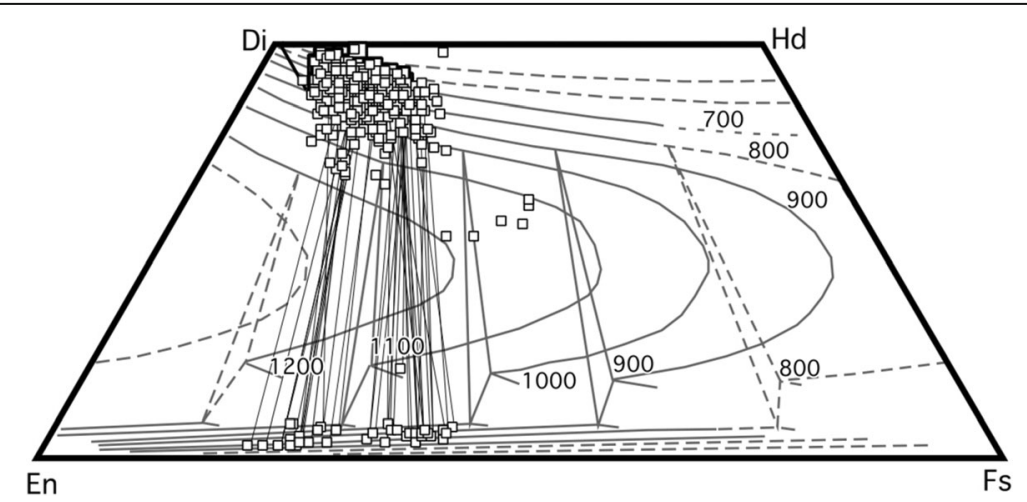

Fig. 12 Tetrahedral components of augite and hypersthene in Atlantis Bank gabbros calculated from Lindsley and Andersen (1983) and contoured for equilibrium temperatures for coexisting pyroxene pairs. The thin black lines are joins connecting coexisting mineral compositions. Temperature contours are in degrees centigrade, whereas dashed lines show inferred extensions of these contours. En, enstatite; Fs, ferrosilite; Di, diopside; Hd, hedenbergite 


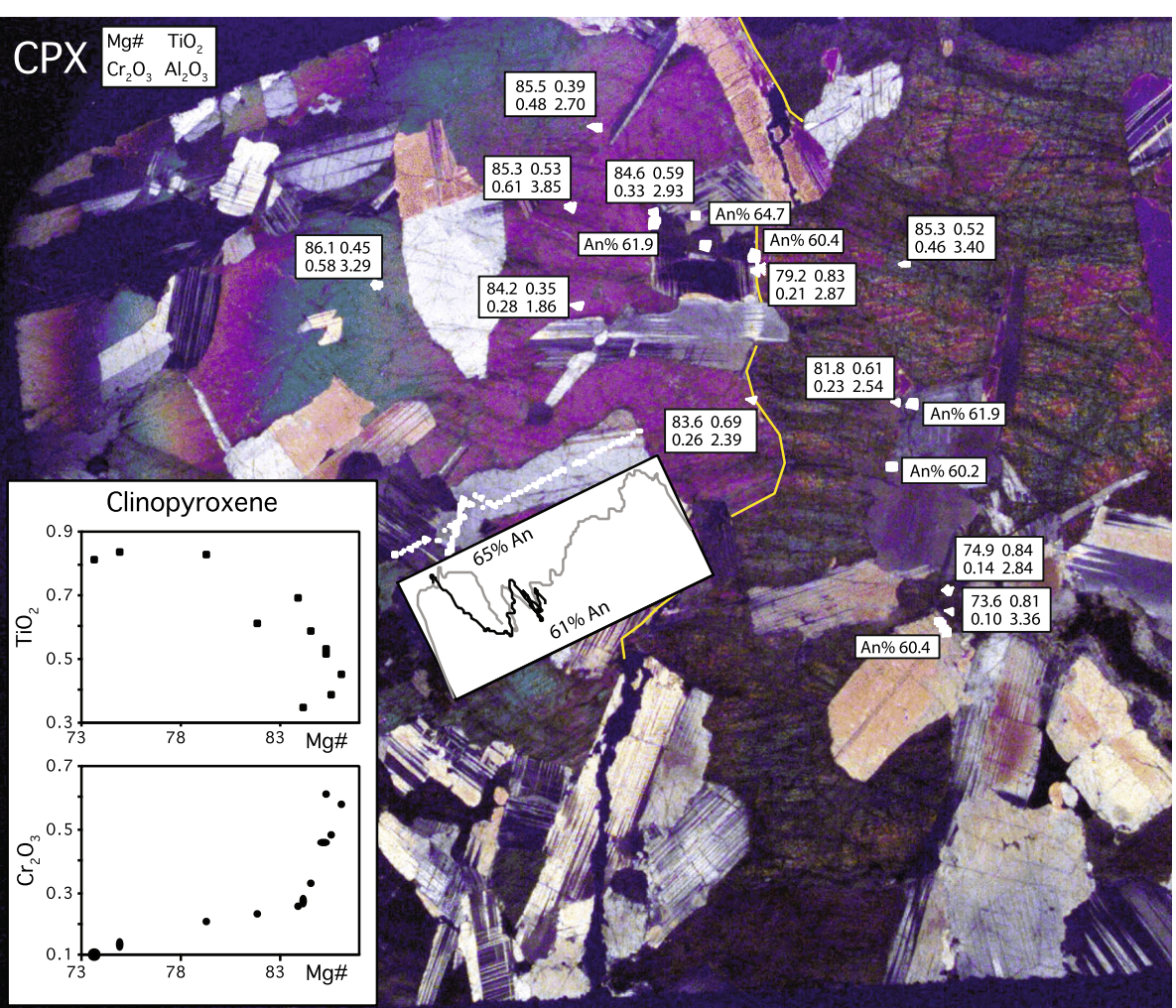

Fig. 13 Thin section microphotograph $4 \mathrm{~cm}$ across under cross polars. Augite oikocrysts in olivine gabbro JR31-12-6, with a curved irregular contact shown by the yellow line. The augite encloses partially resorbed plagioclase chadocrysts but no olivine, which is found elsewhere in the sample. Analytical spots are shown by white points. White boxes next to points give the Mg\#, weight percent $\mathrm{TiO}_{2}, \mathrm{Cr}_{2} \mathrm{O}_{3}$, and $\mathrm{Al}_{2} \mathrm{O}_{3}$ in the pyroxene analyses as indicated by the small inset box in the upper left corner. Large inset shows the $\mathrm{Cpx}$ data in $\mathrm{TiO}_{2}$ and $\mathrm{Cr}_{2} \mathrm{O}_{3}$ versus Mg\# binary plots. Also shown is an inset plot of core to rim plagioclase compositions oriented parallel to the actual line of analytical points for one elongate chadocryst (gray line) and for a shorter crossing traverse (black line). Field of view is $4 \mathrm{~mm}$ across. With the exception of the long, reversely zoned traverse $\left(A n_{65}\right.$ to $\left.A n_{61}\right)$, the compositions of the remaining six plagioclase crystals are very uniform $\left(A n_{61.6+1.7}\right)$. By contrast augite is strongly zoned with Mg\# varying from 74.9 to 86.1 and $\mathrm{Al}_{2} \mathrm{O}_{3}$ from 1.86 to $3.4 \mathrm{wt} . \%$, whereas $\mathrm{TiO}_{2}$ and $\mathrm{Cr}_{2} \mathrm{O}_{3}$ vary inversely by factors of 3- and 7-fold with Mg\#

chemical zoning is not as pronounced in the orthopyroxene as in the augite.

\section{Olivine major element compositions}

Clay, serpentine, talc, chlorite, and magnetite replace much of the olivine in our samples, and as a result our olivine dataset is comparatively small. The forsterite content of olivine expressed as Mg\# ranges from 46 to 80 , averaging 67 , with a median of 69 . No zoning was observed, and olivine has a generally uniform composition within a given sample. Again, there is a broad spread of forsterite content at a given anorthite content, as also seen in Hole 1105A. Although olivine would equilibrate rapidly with an invading melt, this is not the case for plagioclase (e.g., Grove et al. 1984; Yund and Snow 1989). Our data show a continuous variation in composition from $\mathrm{Fo}_{80}$ down to $\mathrm{Fo}_{46}$, which is smaller than for Hole $735 \mathrm{~B}\left(\sim \mathrm{Fo}_{85}\right.$ to $\left.\mathrm{Fo}_{30}\right)$. The pause in olivine-crystallization, seen in many layered intrusions (Bowen and Schairer 1935), is not expressed collectively in our samples or in Hole 735B, although this may occur locally as in Hole 1105A (Casey and Miller 2007).

\section{Hole 735B}

Drilling by ODP and IODP provides major constraints on the evolution of the Atlantis Bank Gabbro Massif. In particular, Dick et al. (2002) compiled 20,504 individual mineral spot analyses of Hole $735 \mathrm{~B}$ gabbros to construct a detailed mineral stratigraphy representing the upper $1508 \mathrm{~m}$ of the gabbro massif (Fig. 15). This stratigraphy is unlike that of any layered intrusion.

First, the enormous range of mineral compositions, particularly in the upper $900 \mathrm{~m}$, generally exceeds the total variation found for any large layered intrusion (e.g., Fig. 15) - a variability that decreases markedly with depth. With some exceptions, the variability decreases below $1200 \mathrm{~m}$ with the disappearance of highly evolved oxide gabbros and gabbronorites, and is similar to that in continental layered intrusions. 

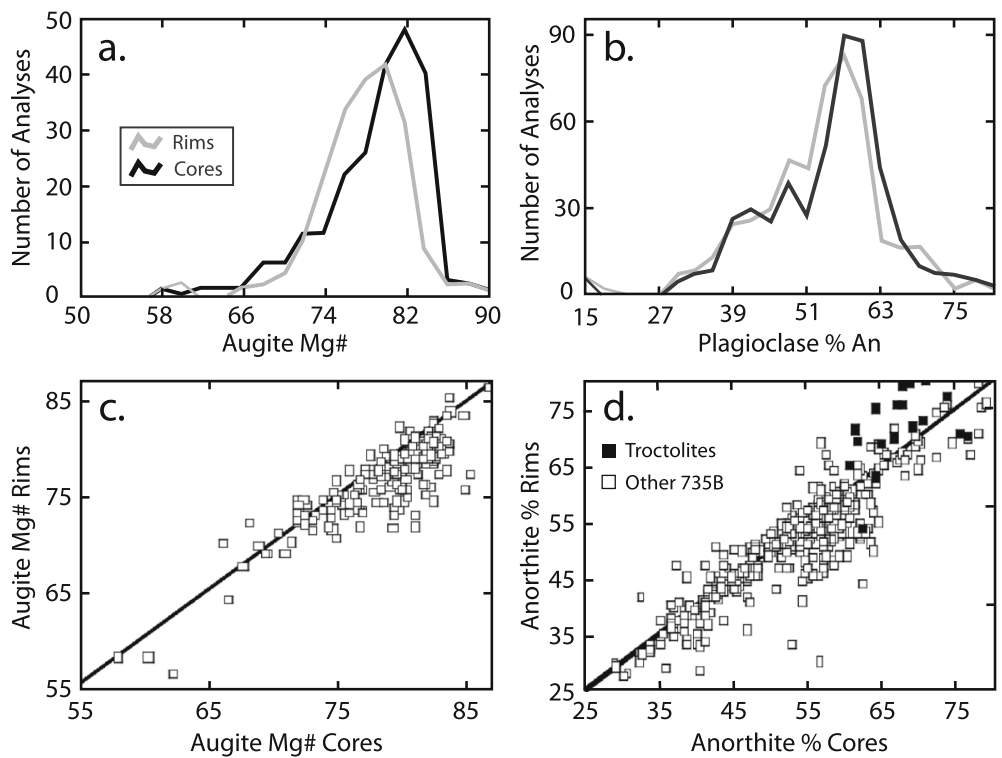

Fig. 14 Core and rim compositions in Hole 735B augite Mg\# and plagioclase anorthite content. a, b Distribution plots for augite and plagioclase cores and rims, respectively. Data are from Dick et al. (2001), and Angeloni and Dick (1990) for troctolite dikes in the upper $550 \mathrm{~m}$ of the hole. $\mathbf{c}$, $\mathbf{d}$ Plots of core vs rim Mg\#'s for augite and core and rim anorthite percent for plagioclase. Black lines show 1:1 proportion of augite Mg\# $(100 \times$ Mg/ $[\mathrm{Mg}+\mathrm{Fe}])$ and plagioclase anorthite content. Except for the troctolites, core-rim data are not generally available for the upper $550 \mathrm{~m}$ of Hole $735 \mathrm{~B}$

Second, there are two mineral stratigraphies, with intercalated olivine gabbros and oxide gabbros defining separate, upwardly differentiated and downwardly differentiated compositional trends. The olivine gabbros have been divided into five upwardly differentiated units, each of which has previously been related to separate intrusive cycles; even here, however, the compositional variability of the olivine gabbro at any one depth often exceeds the total variability of most layered intrusions. The downward differentiation trends, often reaching extreme levels of $\mathrm{Fe}$ and $\mathrm{Na}$ enrichment, are best seen in the upper $500 \mathrm{~m}$ of Hole 735B. There, three such trends are clearly evident in the plagioclase stratigraphy, less so for clinopyroxene, and least for olivine, where only one such trend is clearly evident. Notably, this is consistent with the order in which solid-state diffusion can equilibrate these minerals with an exotic melt. Thus, the olivine stratigraphy best defines local mineral equilibrium with respect to whole-rock composition, whereas the plagioclase stratigraphy defines primary igneous hybridization trends.

Intercalated upward and downward igneous differentiation trends are unheard of in the geologic record on land. Their origin, however, can be deciphered by looking at lithologic variations where evolved oxide-rich gabbros are in contact with more primitive olivine gabbros. Shown in Fig. 16 is a coarse-grained olivine gabbro that is cut by a narrow $1 \mathrm{~cm}$ wide sheared oxide gabbro vein with porphyroclastic pyroxene. In cross-polarized light, it can be seen that plagioclase in the shear zone has been extensively recrystallized due to crystal-plastic deformation (Fig. 16b), and the shear zone is impregnated with abundant interstitial iron-titanium oxides. The pyroxene in the vein and immediately adjacent to it are discolored due to a compositional change, and olivine has reacted away. Thus, a late FeTi-rich melt clearly migrated through the shear zone, hybridizing the olivine gabbro to an oxide gabbro.

The downward differentiation trends are the result of crystal-plastic deformation localizing late-stage, Fe-Ti melts migrating up through the olivine gabbro into hundreds of seams of oxide gabbro along or near zones of strong crystal-plastic deformation (Dick et al. 1991a; Dick et al. 2000; Dick et al. 2002; Dick et al. 1992; Natland and Dick 2001). There, the late melts, far from being in equilibrium with the host olivine gabbro, reacted with it, dissolving olivine and calcic plagioclase and crystallizing $\mathrm{Fe}-\mathrm{Ti}$ oxides in their place along with more sodic plagioclase and iron-rich pyroxene. The downward trends likely do not represent fractional crystallization, but instead are due to variable melt flux, which increased with depth in individual shear zones as deformation and melt flow concentrated into the zones of most intense, and hence most permeable, deformation (Dick et al. 1991a). The $70 \mathrm{~m}$ thick zone at $\sim 200-250$ mbsf in Hole 735B is particularly impressive as an example of where the melt was expelled into a major shear zone by compaction of the crystal mush. With depth, the strength of the deformation increases as the dip of the associated foliation flattens towards horizontal into the principal plane of displacement, sub-parallel to the 


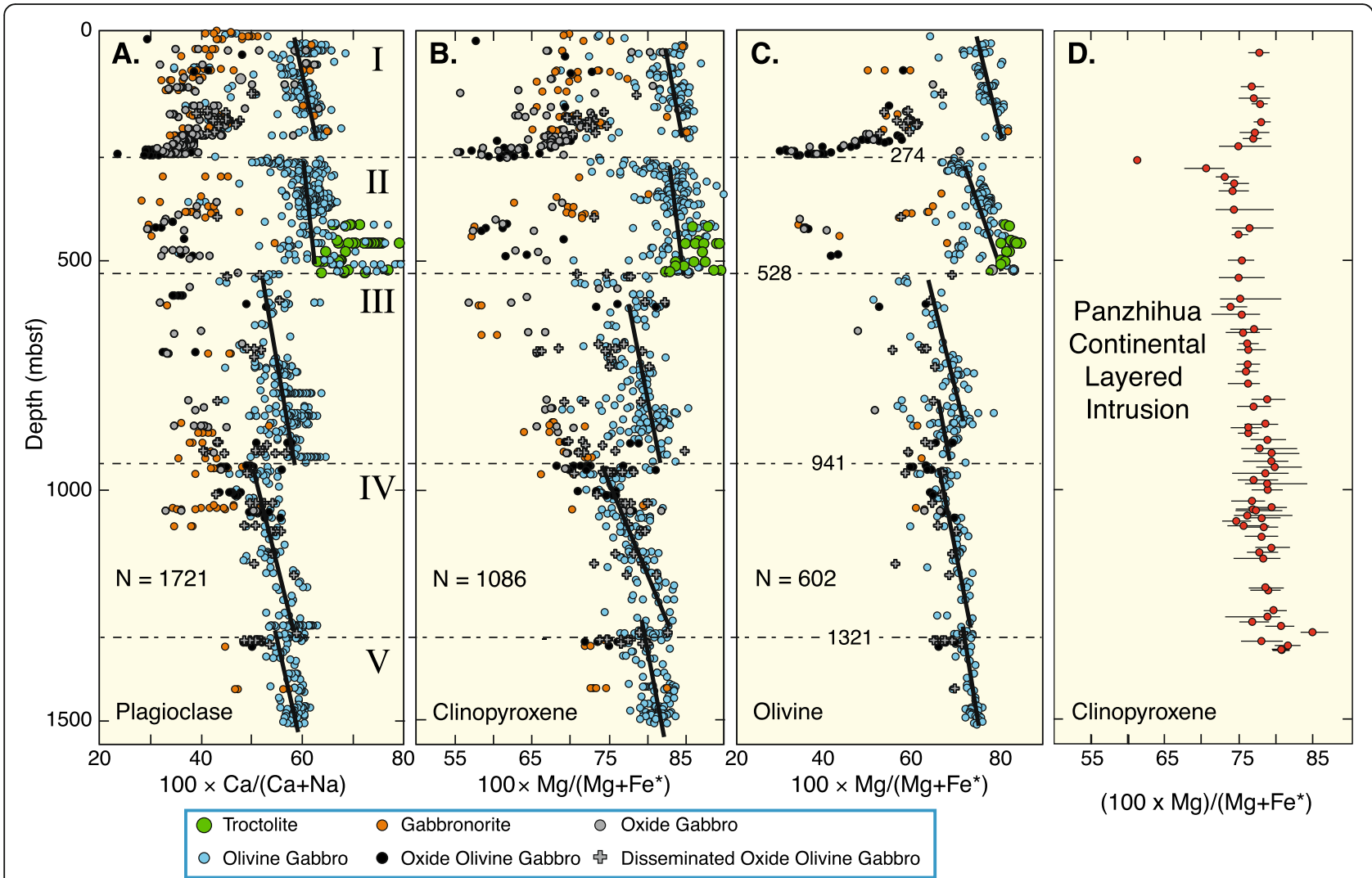

Fig. 15 a-c Down-hole mineral composition plots for Hole 735B plagioclase anorthite content, augite Mg\#, and olivine forsterite content modified from Dick et al. (2002) subdivided by major lithologic groups I to V defined by obvious breaks in the composition of the olivine gabbros. Points represent analytical averages for individual mineral grains. Heavy solid lines are inferred fractionation trends for the olivine gabbros. d Stratigraphic variation of average augite compositions in the Permian Panzhihua layered gabbro intrusion of SW China (Pang et al. 2009). Solid thin lines show the compositional range for each data point

detachment fault footwall. This indicates that the downward differentiation trend and the shear zone could represent an imbrication of the detachment fault where it rooted into the still partially molten gabbro (Dick et al. 1991a).

In this light, the upward increase in lithologic variability throughout the entire $1508 \mathrm{~m}$ Hole 735B gabbro section reflects progressive upward migration of late interstitial melt through the section, locally deflected by shear zones or blocked by permeability barriers in the gabbro (Dick et al. 2000). The enormous crystal-chemical variability at any given depth in the 5 upwardly differentiated olivine gabbro units, then, reflect partial reequilibration of the primary igneous phases with upwardly migrating interstitial melt, and increasing total melt flux with decreasing depth. Thus, this process least affects the deepest units, where little late interstitial melt was retained, and the mineral variability more closely resembles the patterns of crystallization found in large gabbro bodies like the Panzhihua continental intrusion of China (e.g., Fig. 15d).

\section{Regional compositional variations}

In order to look at the regional distribution of mineral chemistry, we show mineral composition plots for coexisting plagioclase, olivine, clinopyroxene, and orthopyroxene in Figs. 17 and 18, divided by geographic region as shown in Fig. 5b. Also shown are the fields for the upper, middle, and lower $500 \mathrm{~m}$ of Hole $735 \mathrm{~B}$ and for all of Hole $735 \mathrm{~B}$ and 1105A. Overall, our data mimic that for Holes 735B but lack both the most primitive and most evolved compositions. The absence of the most primitive compositions is expected because the surface sampling did not recover any primitive troctolites like those in the upper $500 \mathrm{~m}$ of Hole 735B except for a single sample intercalated with olivine and oxide gabbros recovered during Dive 6K-648 on the eastern side of Atlantis Bank.

Overall, there is a strong correlation between the plagioclase and pyroxene compositions that can be interpreted as reflecting progressive fractional crystallization of a moderately evolved basaltic melt. However, as in the ODP drill holes, at any fixed value of plagioclase or pyroxene composition, there are huge ranges in the 


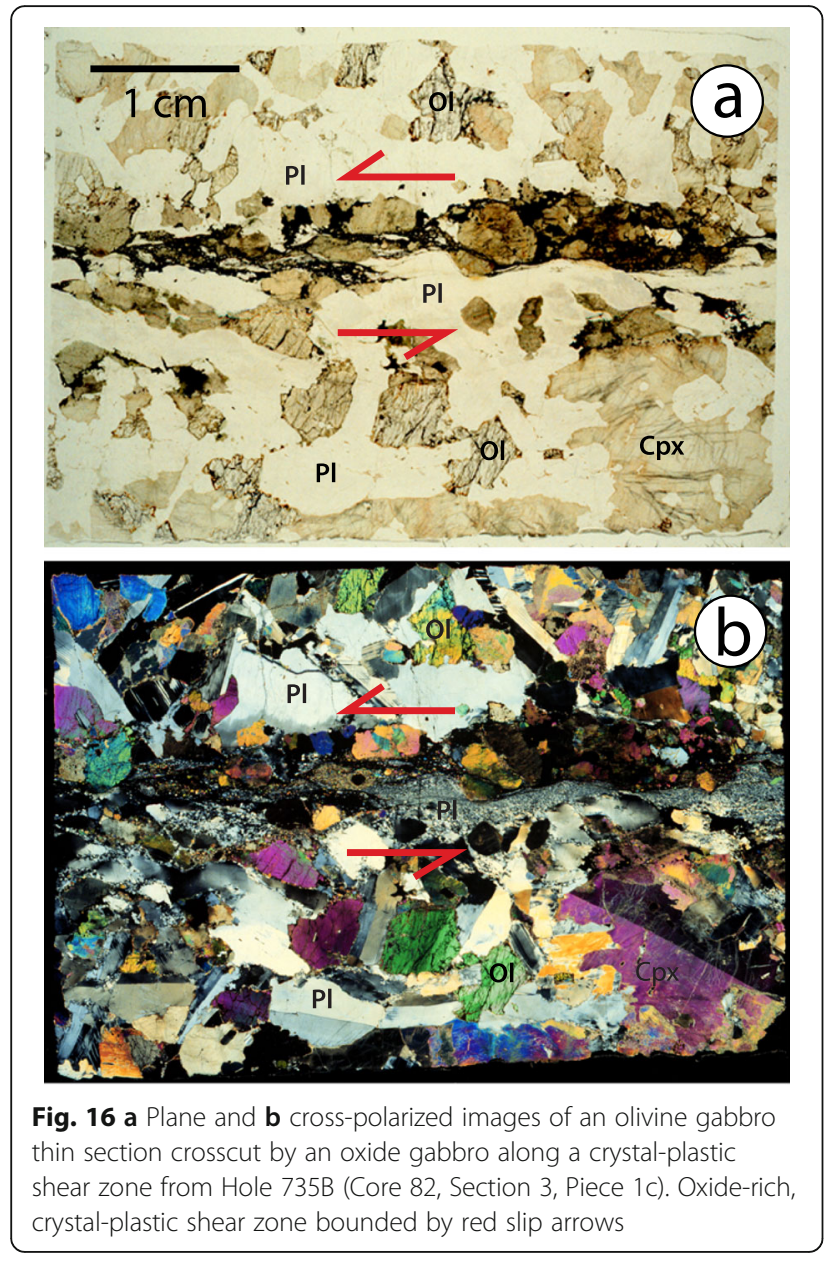

composition of the coexisting phase, generally $\sim 15 \%$ anorthite content, $\sim 10 \% \mathrm{Cpx}$ and Olivine Mg\#. For comparison, the total stratigraphic variation of plagioclase in the $3500 \mathrm{~m}$-thick exposed section of the Skaergaard intrusion is $\mathrm{An}_{25}$ to $\mathrm{An}_{69}$. It is clear then, as for sample JR31-12-6 (Fig. 13), that large-scale disequilibria exist throughout our samples.

\section{Modeling}

Modeling (Fig. 19) shows that the seafloor gabbros are consistent with the products of primitive melts that crystallized $\sim 50 \%$ prior to intrusion and then continued to nearly $90 \%$ fractional crystallization. By contrast, the majority of the ridge basalt glasses would represent 30 to $50 \%$ crystallization of our modeled parental liquid, and the overwhelming majority of our gabbros are too fractionated to have crystallized from any of the basalts. Thus, if they crystallized directly from a melt, it was more highly fractionated than most MORB (Dick et al. 1991a).

There are differences in the gabbro mineral composition ranges in each of our regions, and therefore in their inferred magmatic evolution. Likewise, there are fundamental differences in their tectonic settings, with the northern area consisting of deeply faulted terrains both proximal and distal to the gabbro massif, whereas the western domain is largely distal to it, and the eastern area lies at the center. Sampling in the southern terrain extends across the entire breadth of the massif, including both the detachment footwall and on faults that cut as much as $\sim 1000 \mathrm{~m}$ below it. Accordingly, we provide below both an analysis of the local tectonics and geomorphology of these terrains, and in the context of our modeling and mineral data, construct an overall picture of the gabbro massif.

The huge range in coexisting mineral compositions discussed previously cannot be easily explained by fractional crystallization alone as our modeling shows. To increase the Mg\# of augite by simple fractional crystallization alone of the parent liquids for the seafloor gabbros would require close to $40 \%$ additional fractional crystallization of a primary melt. Rather, it is clear from previous studies that this represents large-scale disequilibria down to the thin section scale (e.g., Fig. 14), reflecting extensive permeable transport and infiltration of exotic melts through the gabbro massif due to compaction and expulsion of interstitial liquids in the crystal cumulates, as also documented in Hole 735B (Dick et al. 2002; Natland and Dick 2002).

\section{Geographical variability}

\section{The northern region}

The northern region includes three east-west-trending volcanic ridges at $32^{\circ} 31^{\prime} \mathrm{S}, 32^{\circ} 35^{\prime} \mathrm{S}$, and $32^{\circ} 40^{\prime} \mathrm{S}$ (Fig. 3). The northernmost (white dashed line in Fig. 3) trends $\mathrm{N} 14^{\circ} \mathrm{W}$ extending from the edge of the map area to the transform wall. A single dredge at its western end recovered pillow basalt. The ridge appears to slope evenly to the north and south on its flanks, indicating that it is an intact volcanic ridge, isolated by a northward ridge jump on the Antarctic Plate. Although the two ridges at $32^{\circ} 35^{\prime} \mathrm{S}$ and $32^{\circ} 40^{\prime} \mathrm{S}$ appear to have intact pillow lava flows on their south faces, their northern slopes appear to be north-facing, high-angle normal faults. These two faults successively propagated along the paleo-rift valley wall and cut across the gabbro massif, instead of merging with it, as they do to the south. Each, in turn, down-dropped the footwall of the main detachment fault by 1500 and $600 \mathrm{~m}$, respectively. Based on a $10 \mathrm{~km} / \mathrm{myr}$ spreading rate and their heave, the faults were active for at least $\sim 690$ and $200 \mathrm{kyr}$, respectively, over a $\sim 1.2$ myr period, creating a large intervening bench at $\sim 2200 \mathrm{~m}$.

The southern $\mathrm{N} 15^{\circ}$-trending ridge at $32^{\circ} 40^{\prime} \mathrm{S}$ extends from the eastern edge of the map area to the eastern edge of the gabbro massif. There, the fault continues as 

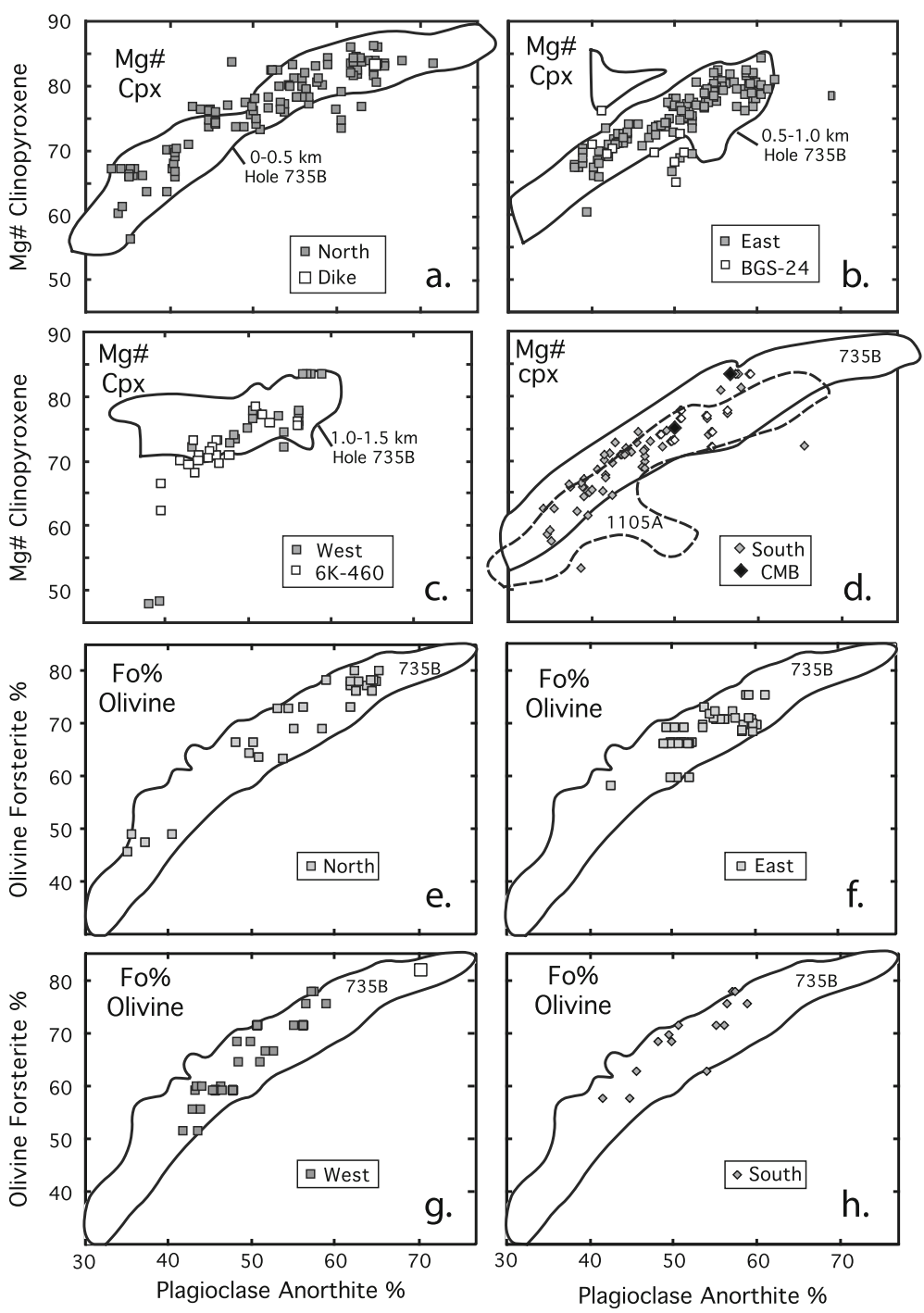

Fig. 17 a-d The composition of coexisting Pl and Cpx for the Atlantis Bank seafloor gabbros plotted by region as discussed in the text. The fields for Hole $735 \mathrm{~B}$ gabbros for $0-0.5 \mathrm{~km}, 0.5-1.0 \mathrm{~km}$, and $1-1.5 \mathrm{~km}$ are shown for reference in panels $\mathbf{a}, \mathbf{b}$, and $\mathbf{c}$ (Dick et al. 2001). d 0-1.5 km Hole 735B field and field for Hole 1105A (Thy et al. 2003). $\mathbf{e}-\mathbf{h}$ The composition of coexisting plagioclase and olivine by region with field for Hole 735B shown for reference

a detachment fault terminating the primary detachment fault at the $2200 \mathrm{~m}$ bench. The bench appears to be covered by a lava field with relatively intact volcanic structures. At the northern edge of the lava field, the $32^{\circ}$ $35^{\prime} \mathrm{S}$ ridge extends across it to where it intersects an enormous landslip on the transform wall. The headwall of the landslip was sampled by Dredges 51, 12, and Dive $6 \mathrm{~K}-655$, and exposes the base of the lava field, which appears to be only 200-300 m thick, erupted over the down-dropped footwall of the core complex. On its southern side, the lavas cover massive gabbro, whereas on the northern side the lava covers an underlying peridotite-dike section that likely fed the overlying lavas.
This indicates that the magmatic center associated with the Atlantis Bank Gabbro Massif either terminated or retreated towards the center of paleo-ridge segment.

\section{Dive 6K-652}

The northernmost dive, 6K-652, traversed up the northfacing slope of an $\sim$ east-west-trending ridge that extends from near the transform floor at least $28 \mathrm{~km}$ to the east (Fig. 20a, b). The ridge is separated by a low saddle from a steep, roughly north-facing detachment fault footwall $3-4 \mathrm{~km}$ to the south at the northern terminus of the Atlantis Bank Gabbro Massif. The slope dips 

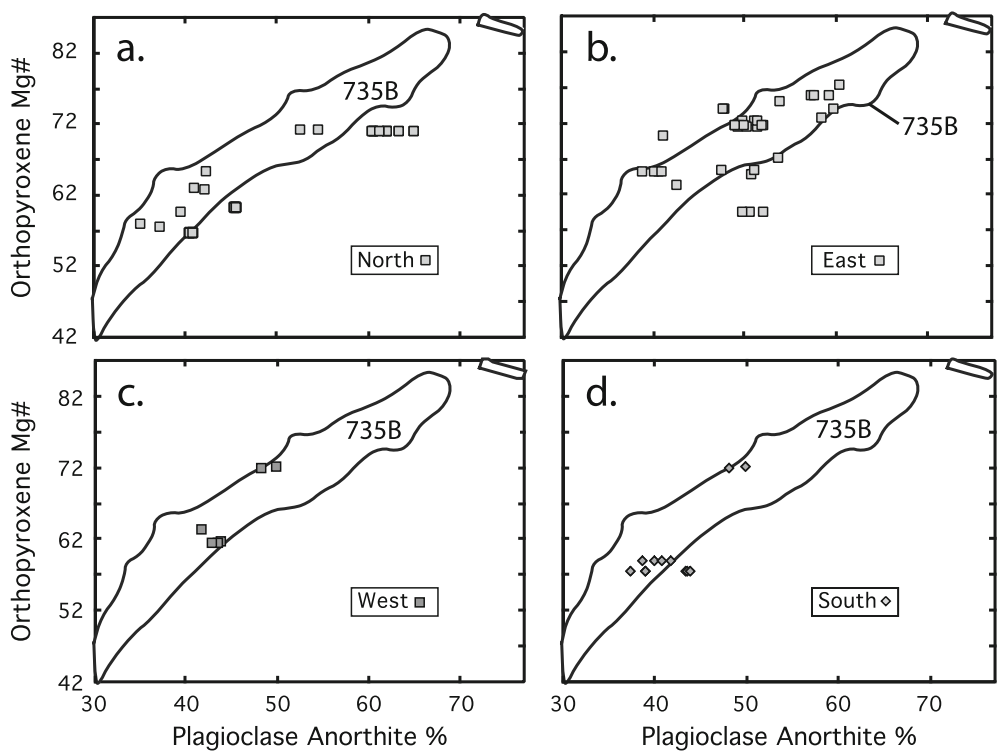

Fig. 18 Atlantis Bank seafloor gabbro orthopyroxene Mg\# plotted against plagioclase anorthite content of coexisting Pl and Opx in the Atlantis Bank dive, dredge and core gabbros: a northern region; $\mathbf{b}$ eastern region; c western region; and $\mathbf{d}$ southern region. The fields represent Hole 735B gabbronorites

steeply $\left(33^{\circ}\right)$ and is a normal fault footwall with a $600 \mathrm{~m}$ throw and $800 \mathrm{~m}$ heave. No slickensides were observed, and the lower slope exposes only weathered pillow lava debris, whereas the middle and upper slopes cut through a stack of intact pillow lavas. The dive did not crest the ridge, but the local seafloor morphology indicates that it is an old east-west-trending axial neovolcanic ridge. Based on the seafloor morphology, the lava flows also extend $3-4 \mathrm{~km}$ south to the base of the main gabbro massif. The lavas are weathered, but otherwise unaltered, and exhibit only brittle deformation.

\section{Dredge 52}

This dredge (Fig. 3) was located on the northern side of the east-west-trending volcanic ridge opposite Dive 6K655 on the south side. It recovered 14 statically serpentinized protogranular peridotites, 9 diabases, and a one undeformed olivine gabbro. Unlike Dive 6K-655, there was a single piece of soapstone, and a near absence of gabbro attesting to northward waning magmatism, whereas the abundant diabase indicates that there was still substantial down-axis volcanism, evidently related to the overlying pillow lavas on the ridge above.

\section{Dive 6K-655}

Dive 6K-655 (Fig. 21a, b) was located on the opposite side of the east-west ridge from Dredge $52, \sim 14 \mathrm{~km}$ east of the active transform fault (Fig. 3a). It sampled up to $\sim 200 \mathrm{~m}$ below the crest but did not encounter the weathered pillow basalt flows sampled by Dredge 50 and Dive 6K-652 despite the east-west-oriented hummocky ridge topography characteristic of an old neovolcanic zone. This suggests that there is only a thin veneer of lavas overlying the plutonic complex sampled by the dive and Dredge 52. The rocks are a mixed assemblage of 7 peridotites, 5 olivine and oxide gabbros, one amphibolite gneiss, and 11 greenschist facies diabase. Two of the gabbros are rodingites, a hydrogrossular-prehnite assemblage characteristic of dikes and small intrusions in serpentinized peridotite (Bach and Klein 2009). The peridotites are serpentinized lherzolites that preserve protogranular and porphyroclastic textures due to static serpentinization. Many are extensively altered to talc and underwent significant deformation and shearing under brittle conditions higher on the dive traverse. The long straight slope, flat, slabby outcrops lying in its plane, and abundant talcose and sheared peridotites indicate that Dive 6K-655 traversed up a down-dropped, and back-tilted portion of the primary detachment fault, that was subsequently covered by lava flows erupted along the east-west-trending ridge. Similar to a large exposure of the detachment fault to the south, there appears to be a thin serpentine veneer that was intruded along the detachment fault from the transform zone. This veneer later localized mass wasting to expose the full sequence on the transform wall.

The sampling indicates that downslope, the detachment fault cut massive granular peridotite intruded by small apophyses of the gabbro massif, whereas upslope it cut through more massive oxide and olivine gabbros. The numerous dikes that cut through both gabbros and peridotites are likely inliers of the dike-gabbro transition 

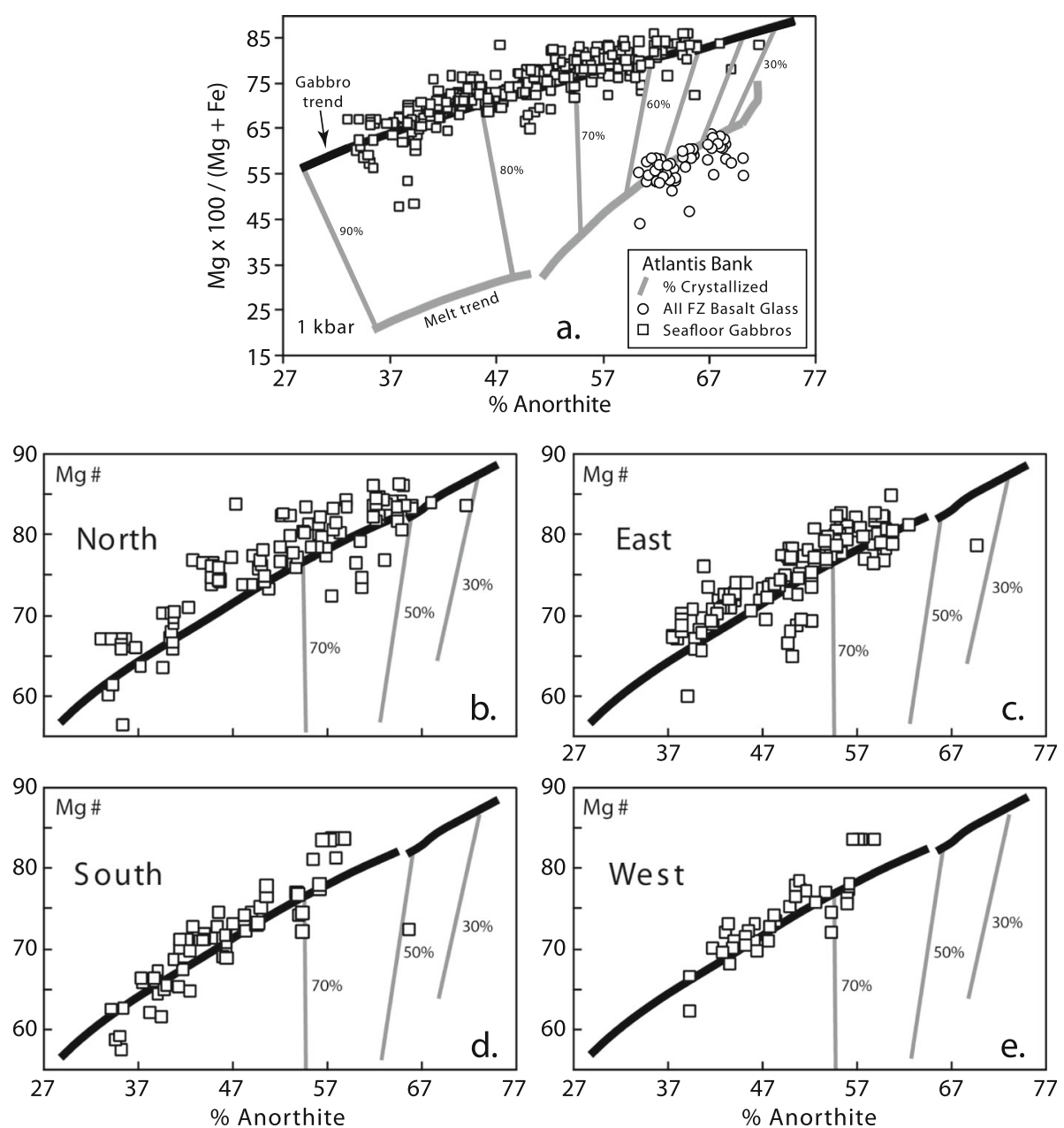

Fig. 19 The distribution of Atlantis Bank mineral compositions relative to modeled liquid and solid lines of descent modeled for $1 \mathrm{~kb}$ using Ghiorso and Sack (1995). Gray bars connect equilibrium melt and plagioclase compositions using the most primitive MORB glass from Dick et al. (2000) as a starting composition for 30-90\% crystallization. a Atlantis Bank seafloor gabbro sample plagioclase anorthite contents (upper data array) and $\mathrm{Ca} \times 100 /(\mathrm{Ca}+\mathrm{Na}$ ) for present day ridge segment glasses (lower array) plotted against the coexisting augite and glass Mg\#. $\mathbf{b}-\mathbf{e}$ The predicted solid line of descent from panel $\mathbf{a}$ and the plagioclase and augite compositions for the northern, eastern (top of bank), southern, and western regions, respectively

and dike-mantle transitions where the gabbro massif pinched out near the transform.

\section{Dive 646}

Dive 646 (Fig. 21b, c) was located at the intersection between the transform wall and the north-dipping footwall of the secondary detachment fault. The dive traversed up a long east-southeast-trending ridge, sampling across the gabbro-mantle contact, and ended in an inlier of massive dikes $2800 \mathrm{~m}$ below the detachment fault footwall. Numerous small landslips cut the slope on both sides of the ridge, and most of what was collected is talus. The dive sampled 4 weakly deformed (C-P 0.5), protogranular peridotites and 3 undeformed olivine and oxide gabbros, along with 13 diabase largely in float from 4569 to $4372 \mathrm{~m}$, followed by dikes and peridotite in possible outcrop at $\sim 4300 \mathrm{~m}$. It then passed up the northern side of a small landslip headwall, encountering first undeformed oxide-olivine gabbro float, and then diabase float from 3815 to $3520 \mathrm{~m}$.

This dive showed that the gabbro massif thins dramatically at its northern end with only a thin intervening gabbro layer intruded into mantle peridotite cut by massive diabase dikes (Fig. 21c). The massive, granular nature of the peridotites, and lack of crystalplastic deformation in the gabbros, indicate that the contact is intrusive and sharp. Unlike Dive 6K-655, the peridotites are not talcose and underwent static serpentinization. The dikes found upslope in float indicate that there is an inlier of the dike-gabbro transition. 
a.

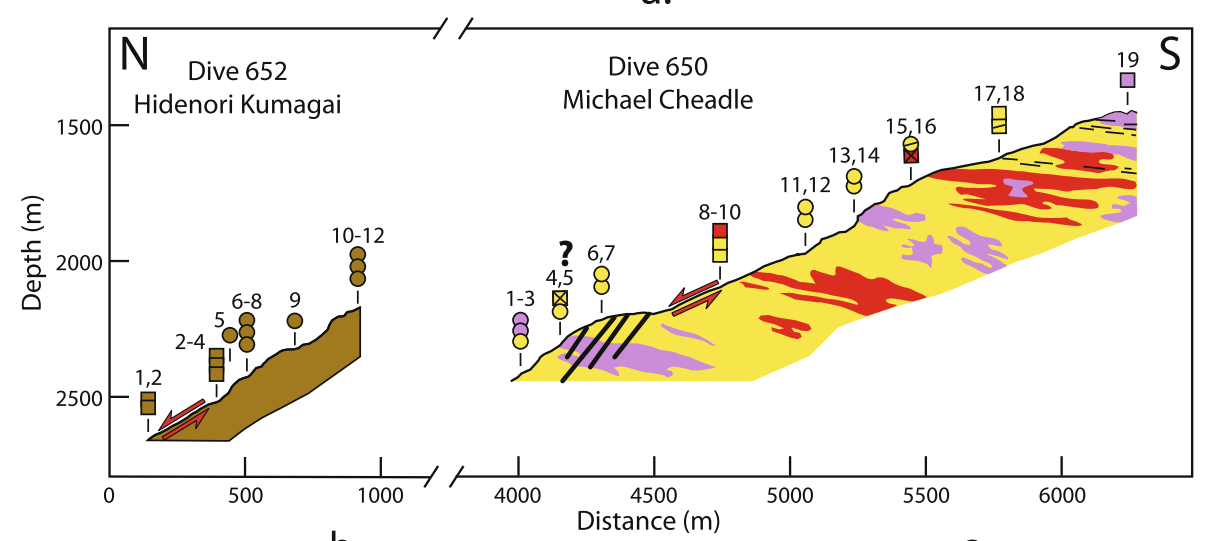

b.

$57^{\circ} 16^{\prime} \mathrm{E}$

$57^{\circ} 13^{\prime} \mathrm{E} \quad \mathrm{C}$.

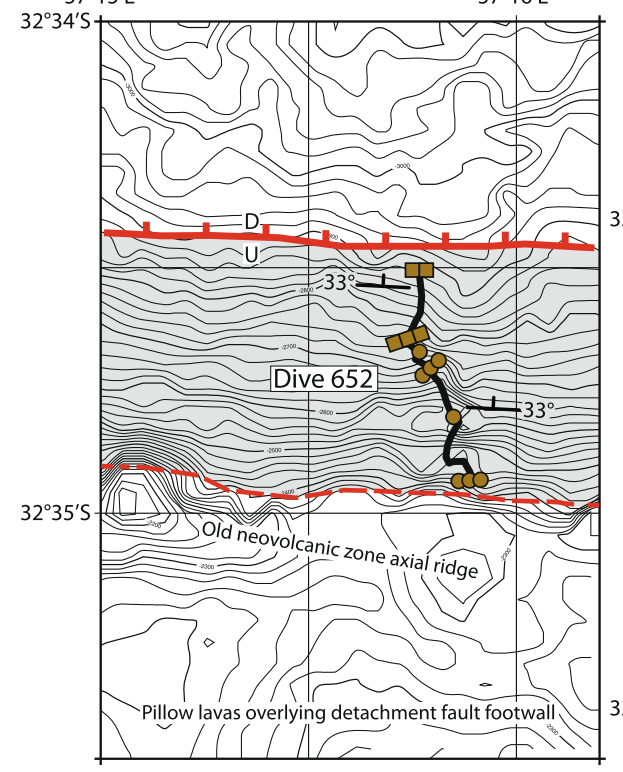

Lithology

$\begin{array}{ll}\text { O } & \text { Pillow Basalt } \\ \text { O } & \text { Oxide gabbro } \\ 0 & \text { Metagabbro } \\ 0 & \text { Olivine Gabbro }\end{array}$

$\ominus$ Schist or mylonite

O From or on outcrop

$\square$ Talus/rubble

$\otimes$ Fault Gouge
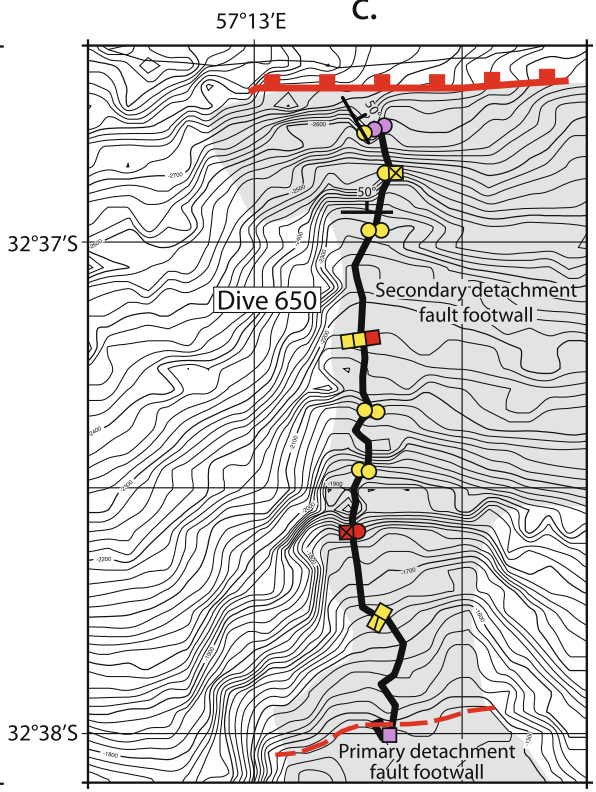

Structure

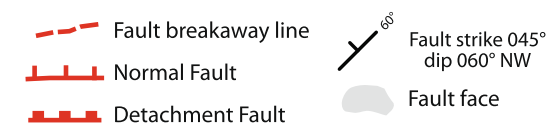

Fig. 20 a Geologic interpretations of Dives 652 (left) and 650 (right) on the $32^{\circ} 35^{\prime} \mathrm{N}$ and $32^{\circ} 40^{\prime} \mathrm{S}$ secondary detachment fault faces, respectively. b Dive 652 plan view showing high-angle normal fault face. Thick black lines are navigated dive tracks. c Dive 650 traverse up the north-facing secondary detachment footwall and the fault breakaway zone separating it from the primary detachment fault footwall at the north end of the Atlantis Bank gabbro massif. Profiles represent distance along track, rather than a straight line up a constant azimuth. Scientific divers H. Kumagai and M. Cheadle as indicated on the cross-sections

Although only olivine gabbro was analyzed from Dive 646 (\#'s 1, 4 and 6), they have Cpx with Mg\# 76.9 to 83.7 and plagioclase with An 49.7 to An 71.5, significantly more primitive than all but the uppermost gabbros from the 466-467 traverse near the transform, representing $\sim 35$ to $40 \%$ crystallization of our model melt. A more primitive composition may be consistent with gabbros being emplaced into the crust as magma flux wanes and the lower crust is thin at the end of a major magmatic event.

\section{Dive $6 \mathrm{~K}-650$}

Dive 6K-650 (Fig. 20a, c) went up a north-dipping, secondary, detachment fault footwall with a dip of $24^{\circ}$, a throw of $1300 \mathrm{~m}$ and a heave of $2700 \mathrm{~m}$ and sampled a section midway between the center of the massif and the transform. This secondary detachment fault face terminates below the dive track at $\sim 2700 \mathrm{~m}$ depth and runs up to the breakaway zone at $1450 \mathrm{~m}$ where it cuts the primary detachment fault footwall. Eighteen gabbros and a cataclasite (6K-650-R05) were collected from this section. 


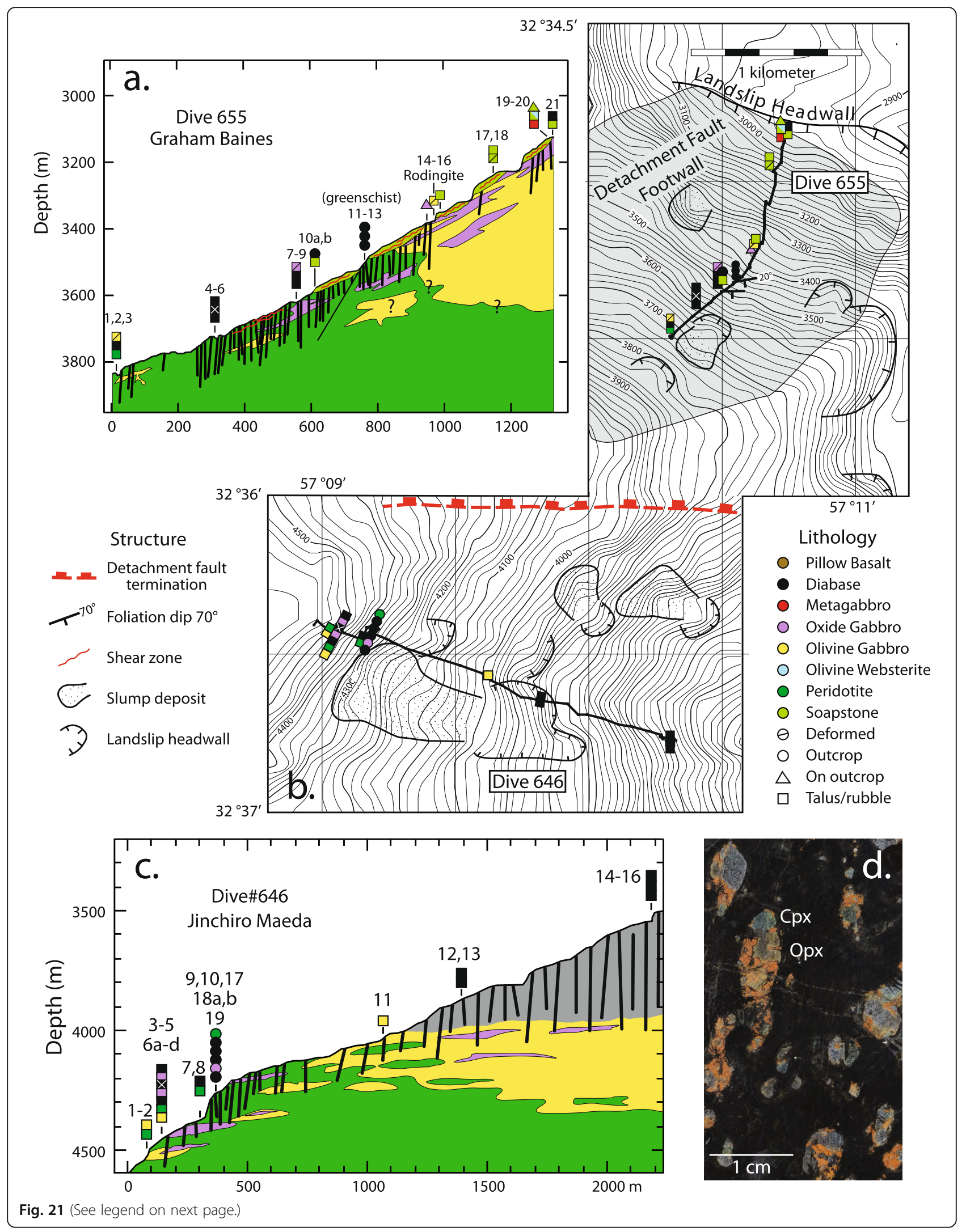


(See figure on previous page.)

Fig. 21 Shinkai 6500 Dives at the northern terminus of the Atlantis Bank Gabbro Massif. Heavy sub-vertical lines represent dikes. Note that dikes are oriented east-west, parallel to the cross-section, but are shown as though they were oriented north-south perpendicular to the section for illustration. a Geologic interpretation of Shinkai Dive 655 with sample locations. b Plan view of Shinkai Dives 655 and 646 with the headwalls and slump toes of landslips inferred from the bathymetry. c Geologic interpretation of Shinkai Dive 646 with sample locations. $\mathbf{d}$ Photo of Dive 646 porphyroclastic Iherzolite 6K 646-R08 showing fresh porphyroclastic enstatite (gray mineral), weathered relict olivine (orange clay), and black serpentine matrix after olivine representing static alteration indicating that the sample is from a massive peridotite outcrop, not a sheared serpentinite fault gouge

Eleven Dive 6K-650 gabbros are crystal-plastically deformed, ranging from weakly recrystallized (C-P 0.5, Fig. 22a) to ultramylonite (C-P 5.0, Fig. 22b). There is an extensive greenschist facies and cataclastic overprint in many of the samples (e.g., Fig. 22c). This overprint is consistent with hydrothermal circulation up a shallow brittle fault zone, whereas the hightemperature $\left(\sim 650-1000{ }^{\circ} \mathrm{C}\right)$ crystal-plastic deformation (Fig. 22b, c) reflects the earlier tectonic event associated with the initial unroofing of the main gabbro massif on the primary detachment fault. This was also overprinted in turn by amphibolite facies alteration during the first event. During the later cross faulting, with formation of the secondary detachment fault, the gabbros underwent cataclasis (e.g., Fig. 22d) and alteration at greenschist facies temperature or lower.

The proportion of oxide gabbros recovered by Dive $6 \mathrm{~K}-650(16 \%)$ is significantly less than that sampled in the upper $500 \mathrm{~m}$ of Hole $735 \mathrm{~B}$ but similar to that in the middle $500 \mathrm{~m}$. Olivine gabbros 6K-650 R4, R6, and R9 were analyzed, and they represent some of the most primitive Atlantis Bank seafloor gabbros, with $\mathrm{An}_{53.0}$ to $\mathrm{An}_{64.7}$ plagioclase and $\mathrm{Cpx} \mathrm{Mg} \# 80.1$ to 84.9. On the basis of the plagioclase composition, the most primitive of these would have crystallized from a liquid corresponding to $\sim 52 \%$ crystallization of our model parent basalt.

\section{Dredge 12}

This dredge (Fig. 3) was located $5 \mathrm{~km}$ to the east of Dive $6 \mathrm{~K}-655$, and also sampled up the south side of the eastwest ridge, again ending $\sim 200 \mathrm{~m}$ below its crest. It recovered 69 rocks: $35 \mathrm{~kg}$ of oxide gabbro and $72 \mathrm{~kg}$ of olivine gabbro with the characteristic textural and modal diversity seen in other Atlantis Bank sample suites (Fig. 23). Augite in 12 samples averages Mg\# 78, ranging from 56.6 to 86.3 , with large variations in individual samples (e.g., Fig. 14a), attesting to large local disequilibrium. The olivine gabbros have very little crystal-plastic

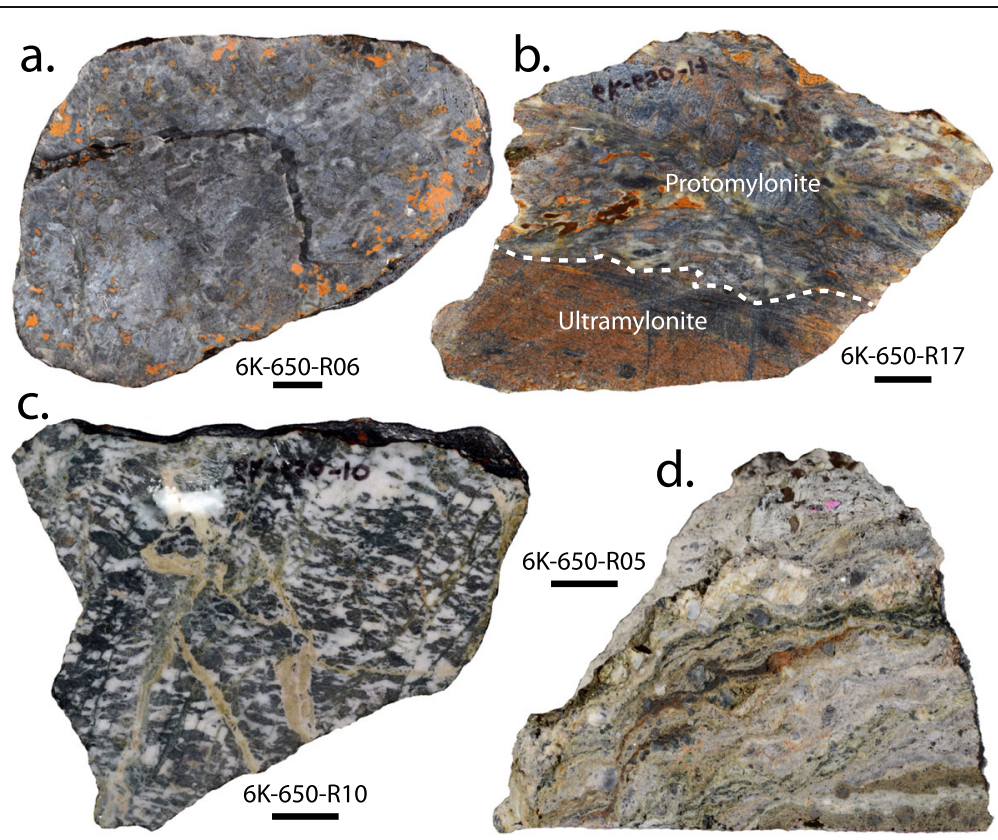

Fig. 22 Dive 650 gabbros: a Equigranular olivine gabbro with intergranular olivine weathered to bright orange clay on margins. b Olivine gabbro variably deformed from protomylonite to ultramylonite. c Amphibolite gneiss crosscut by zoisite (brown), actinolite/chlorite (pale green), prehnite (pink), and quartz veins. $\mathbf{d}$ Silicified gabbro cataclasite with hydrothermally altered pyroxene fragments, comminutated plagioclase, and milky quartz. Foliation defined by deformed mineral schlieren. Black bars $=1 \mathrm{~cm}$ 


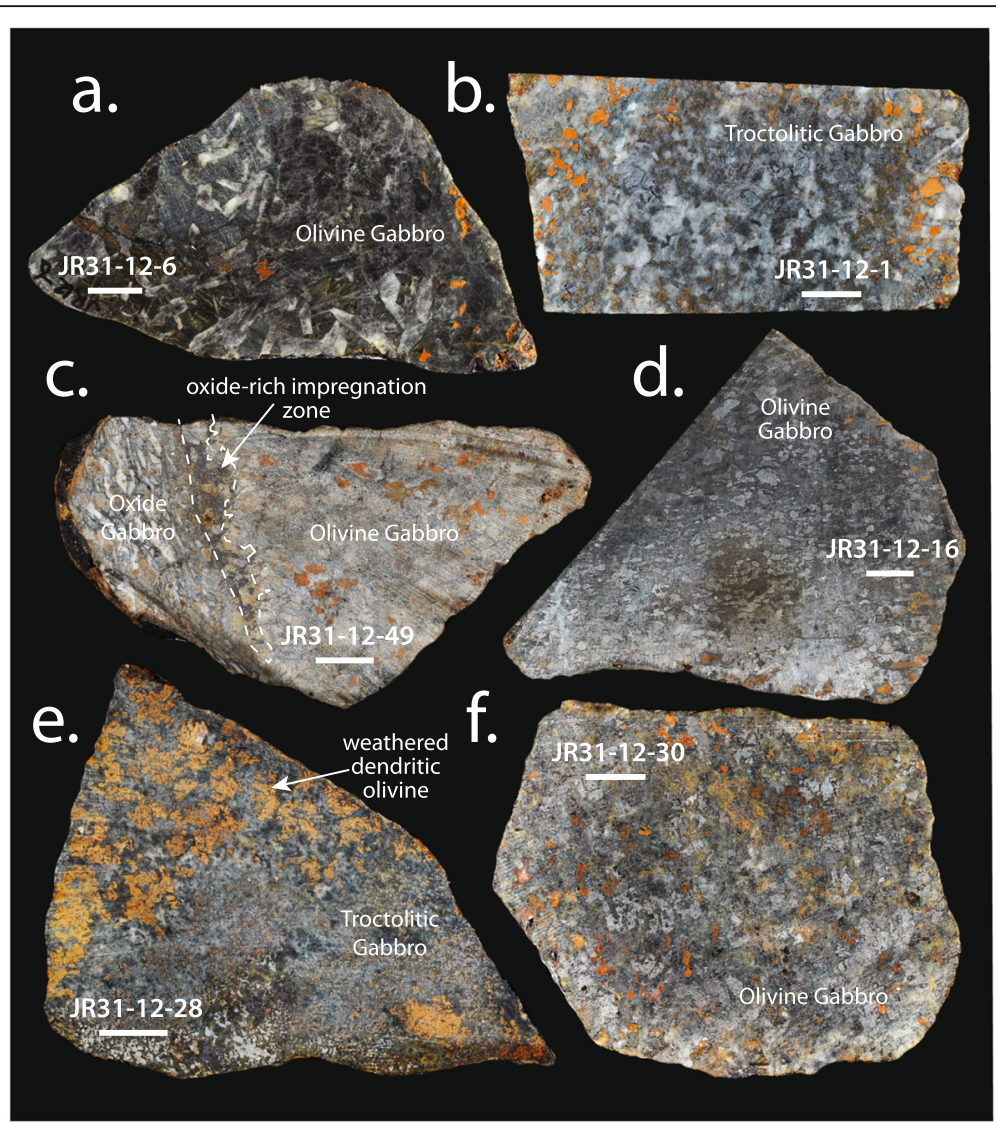

Fig. 23 Examples of Atlantis Bank seafloor olivine gabbros selected from Dredge JCR31-12 from a landslip headwall at the northern end of the gabbro massif (Fig. 3). a Undeformed intergranular olivine gabbro with large centimeter-scale plagioclase laths. b Olivine troctolitic-equigranular gabbro with orange clay replacing olivine on margins. c Equigranular olivine gabbro crosscut by a high-temperature (e.g., $600-1000^{\circ} \mathrm{C}$ ) protomylonite oxide gabbro imaged dry to enhance Fe-Ti oxides impregnating and replacing the silicate matrix of the undeformed olivine gabbro adjacent to the contact. d Equigranular olivine gabbro with a possible weakly deformed magmatic foliation grading from coarse- to medium-grained gabbro perpendicular to the foliation. e Unusually olivine-rich, troctolitic gabbro with dendritic-structured olivine intergrown with equigranular sub-millimeter-scale augite and plagioclase chadocrysts. $\mathbf{f}$ Olivine gabbro with characteristic sub-ophitic augite and intergranular plagioclase

deformation, which is prominent in other Atlantis Bank suites. By contrast, although some oxide gabbros appear undeformed with up to $10-15 \%$ intergranular oxide, many show significant high-temperature crystal-plastic deformation, even where it crosscuts undeformed olivine gabbro (e.g., Fig. 23c). In the latter case, Fe-Ti oxides partially statically replace the silicates along grain boundaries in the olivine gabbro adjacent to the contact. This is consistent with localization of late $\mathrm{Fe}-\mathrm{Ti}$ rich melt along the shear zone, and its reaction with the host olivine gabbro at its margins.

The Dredge 12 gabbros have anorthite 35.3 to 64.9 plagioclase, averaging $54.7 \pm 7.7(1 \sigma)$ and augite $\mathrm{Mg} \#$ 56.6 to 86.3 , averaging Mg\# 78, lacking only the most fractionated and most primitive gabbros found in the upper $500 \mathrm{~m}$ of Hole 735B. Thus, except for the lack of crystal-plastically deformed olivine gabbro, the $\sim 600 \mathrm{~m}$ dredge section is mechanically, lithologically, and mineralogically essentially identical to the upper $500 \mathrm{~m}$ of Hole 735 ( $32 \%$ oxide gabbro). Its position, along with that of the ODP and IODP holes, is close to the centerline of the gabbro massif. Holes U1473A and 1105A are equally similar to the upper $500 \mathrm{~m}$ of Hole 735B (Dick et al. 2017), thus extending the stratigraphic continuity of magmatic processes along the north-south centerline of the Atlantis Bank Gabbro Massif from $~ 250$ kyr (Dick et al. 2017; MacLeod et al. 2017a) to $\sim 1.3$ myr.

\section{Dives 466 and 467}

Dive $6 \mathrm{~K}-466$ continuously sampled up an $\sim 28^{\circ}$ slope across the gabbro-peridotite contact at $32^{\circ} 38^{\prime} \mathrm{S}$ to $200 \mathrm{~m}$ below the eroded primary detachment fault footwall (Fig. 24). This represents a diagonal section through the crust from the mantle up the transform wall to a point $\sim 5 \mathrm{~km}$ to the east. The lower section of the traverse slopes at $36^{\circ}$ and consists of discontinuous outcrop 


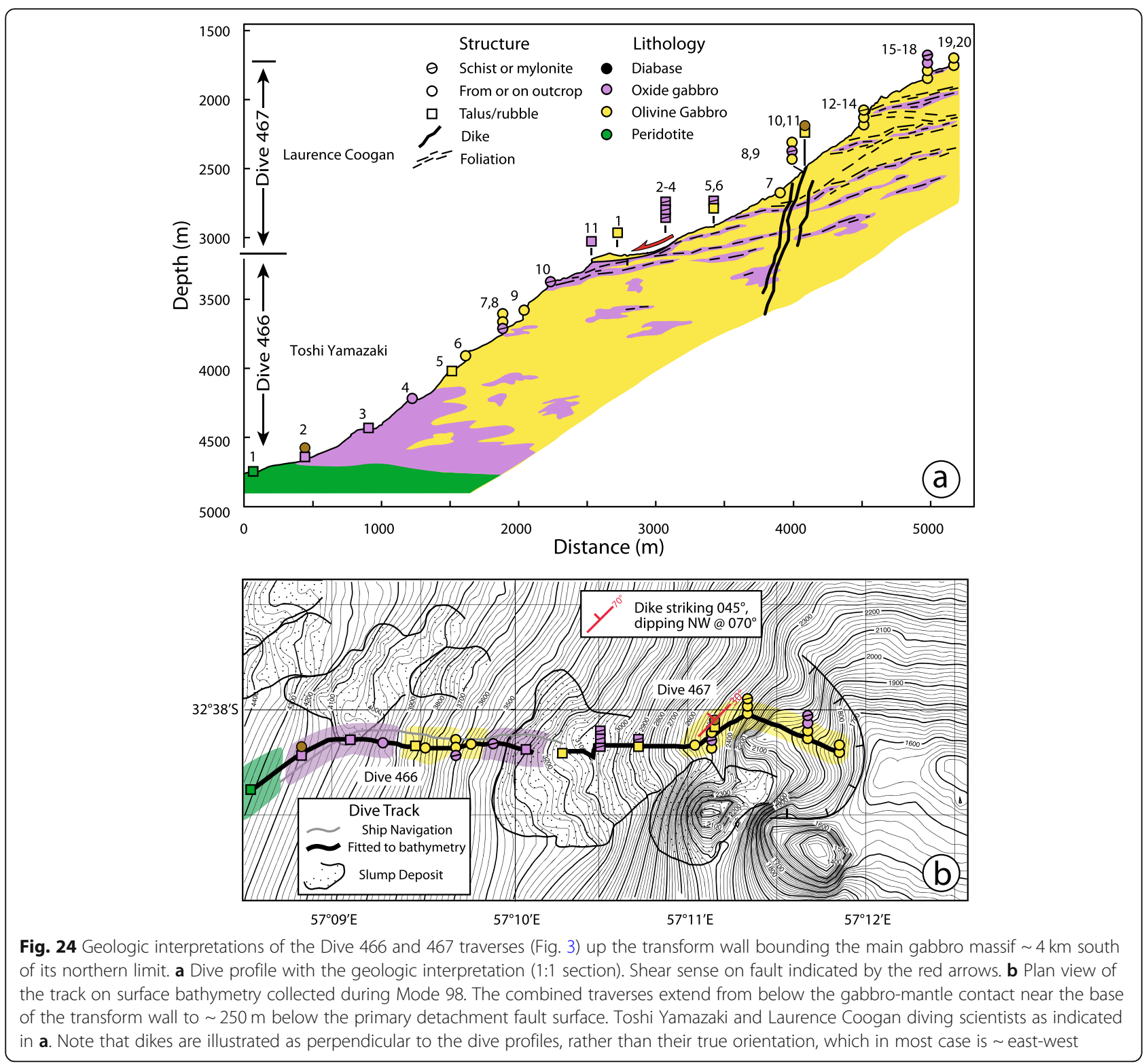

from $\sim 4400$ to $\sim 3200 \mathrm{~m}$ and is likely a degraded fault surface. The upper portion has a dish-shaped depression covered in talus consistent with a slump scar and toe indicated by the red arrow in Fig. 24a. This uplifted block likely formed due to local isostatic compensation following a spreading direction change that put the transform into transtension, triggering a $\sim 2 \mathrm{~km}$ uplift of the transverse ridge flanking the Atlantis II Transform (Baines et al. 2003; Dick 1991b).

Although the original core complex footwall would have dipped more gently towards the transform, as it does to the south at $\sim 13^{\circ}$, the degraded slope sampled along the traverse clearly cuts that surface (Fig. 3a). Assuming a similar slope for the original detachment surface to that to the south, we estimate that the wall exposes a diagonal section through the gabbro that cuts down a maximum of $1700 \mathrm{~m}$ below the detachment footwall.

Dive 466 sampled coarse porphyroclastic peridotite (C-P 1.0) at $4714 \mathrm{~m}$ (Fig. 25a), then an oxide-olivine gabbro (Fig. 25b) at $4614 \mathrm{~m}$, followed by undeformed olivine gabbro at $4410 \mathrm{~m}$ all in float and talus on a progressively steeper slope and another undeformed olivine gabbro on outcrop at $4200 \mathrm{~m}$, indicating that the gabbro-peridotite contact here is intrusive. This was followed by a succession of olivine and oxide gabbros in outcrop up to disseminated oxide gabbronorite talus at the foot of the slump toe at $3225 \mathrm{~m}$. From $3906 \mathrm{~m}$ upward both deformed and undeformed gabbros were sampled, including mylonites. Dive 6K- 


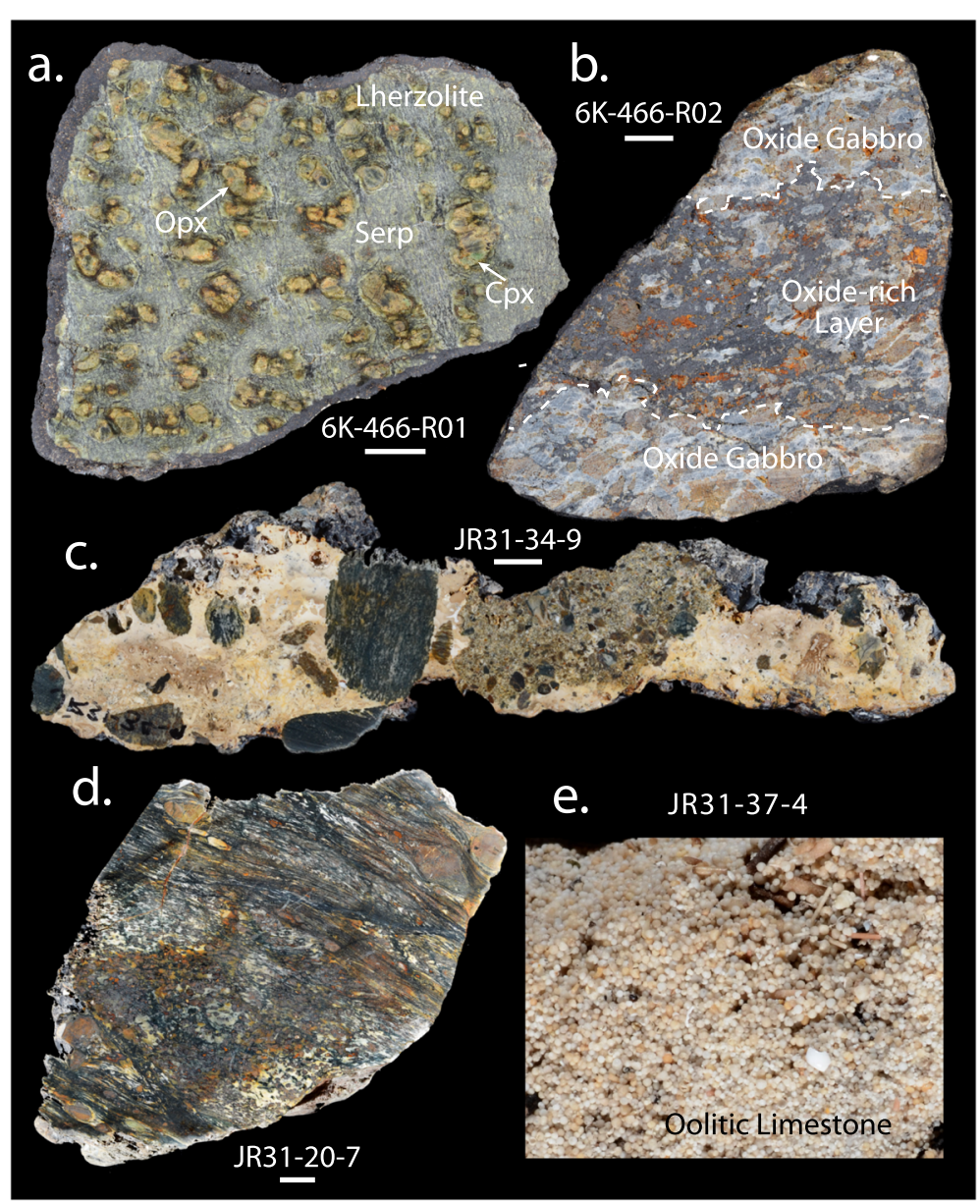

Fig. 25 Selected samples from Dives 466 and James Clark Ross Cruise 31 Dredges 20, 34, and 37 (see Fig. 3). a Porphyroclastic granular Iherzolite (C-P 1) from $4714 \mathrm{~m}$ depth below the gabbro-mantle contact, with serpentine replacing olivine, but only minor replacement of enstatite and diopside (green pyroxene on lower left). b Moderately deformed (C-P 1.0) layered oxide-rich olivine gabbro from above the gabbro-mantle contact at $4614 \mathrm{~m}$ depth. c Bioclastic limestone cemented conglomerate from an old submerged shoreline on the western perimeter of the wave-cut platform at $934 \mathrm{~m}$, with serpentinite, gabbro, poorly sorted sandstone, and milky quartz cobbles and clasts. d Partially amphibolitized olivine gabbro mylonite and augen gneiss from the eastern flank of the wave-cut platform. Note the deep pitting of the edges of the slabs interpreted as due to sub-aerial and shallow marine weathering, particularly on the edge of the otherwise well-rounded gneiss cobble in image c. e Oolitic limestone from edge of the northern shelf

467 sampled olivine and oxide gabbro on the slump toe from 3122 to $2920 \mathrm{~m}$ and olivine and oxide gabbros in outcrop in the slump headwall up to the end of Dive 6K-467 at $1755 \mathrm{~m}$. The Dive 6K-467 gabbros are variably deformed as are the upper Dive 6K-466 gabbros, again ranging up to mylonite intercalated with undeformed gabbros. A single well-exposed diabase dike (6K-467 R11) was sampled at $2520 \mathrm{~m}$. This dike has an anomalously primitive composition compared to the spatially associated gabbros and thus appears to be an unrelated late intrusion.

Plagioclase and augite compositions for the 6K-466 and -467 gabbros are plotted in Fig. 26. Gabbros from above $3000 \mathrm{~m}$ have augite ranging from $\mathrm{Mg} \# 71.7$ to 84.3, averaging 77.0, and plagioclase ranging from An 44.7 to 64.6 , averaging 50.0. The most evolved gabbros are mid-depths between 3000 and $4000 \mathrm{~m}$ with augite Mg\# 60.3 to 81.3, averaging 68.9, and plagioclase ranging from An 32.9 to 58.2, averaging 40.8. More primitive gabbros then appear below $3000 \mathrm{~m}$, similar to those in Dive 646, with augite $\mathrm{Mg} \# 76.6$ to 77.3 averaging 77.3, and plagioclase ranging from An 42 to 51.8, averaging 47.7 (Fig. 26). Notably, olivine gabbros are most abundant in the upper and lower sections, whereas oxide gabbros are more abundant in the mid-depths, consistent with the overall variations in mineral chemistry. Nineteen core-rim analyses gave 5 normal and 6 reversely zoned Cpx greater than $1 \sigma$, not significantly different from our dataset as a whole, which contrasts to the zoning in the lower kilometer of Hole 735B.

The lowermost gabbro in Dive $6 \mathrm{~K}-466$ is a weakly foliated (C-P 0.5) oxide-olivine gabbro that was not 


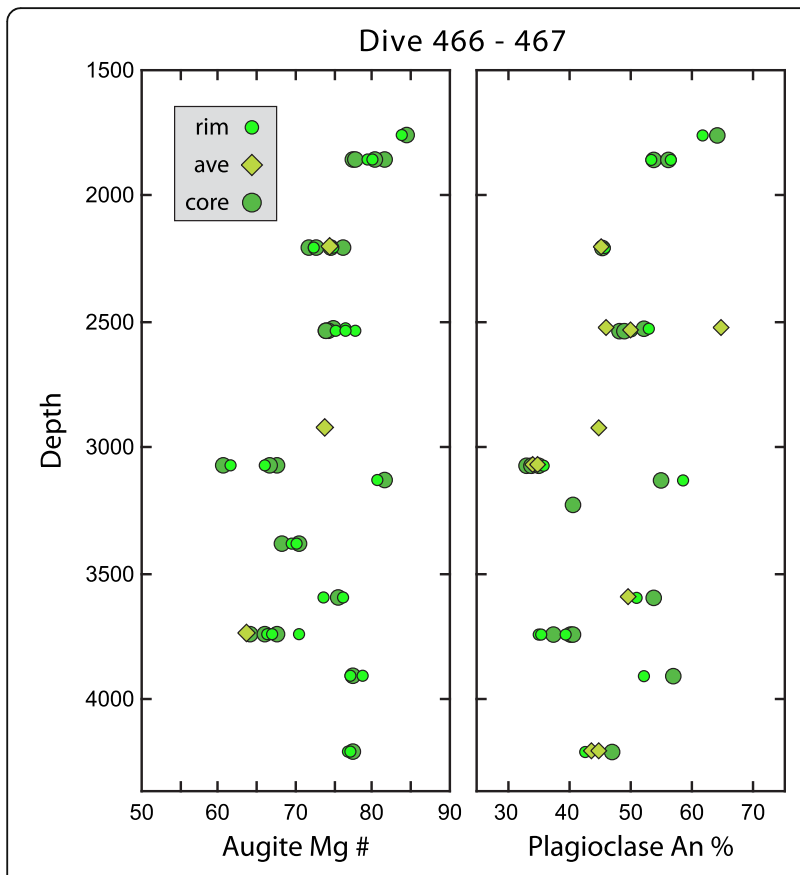

Fig. 26 Augite Mg\# and plagioclase anorthite content plotted against sampling depth for Shinkai 6500 Dives 466-467 on the north wall of Atlantis Bank (Fig. 3). These dives represent a continuous traverse of the largest gabbro exposure at Atlantis Bank, ending at the contact with the mantle on the transform wall. This shows that the contact is not a depositional one representing the gabbroperidotite contact, but rather an intrusive contact where evolved gabbro intruded laterally into the mantle in the transform zone

suitable for analysis. The first gabbro analyzed, 6K-466R04, is an undeformed olivine gabbro sampled on outcrop at $4200 \mathrm{~m}$. The latter is moderately evolved with Mg\# 76.6-77.2 augite and An 42.7-46.8 plagioclase. Thus, the gabbros at the contact with the peridotite, are not early cumulates from a primary magma but crystallized from a highly fractionated melt representing 78\% model crystallization of our parental basalt indicating that the contact is laterally intrusive rather than subhorizontal and depositional.

Gabbros from Dives 466 and 467 are generally less primitive than other gabbros from the northern region. Thus, mineralogically this section closely resembles the upper $500 \mathrm{~m}$ of Hole 735B. A notable difference, however, is that the length of the section is $\sim 3$ times longer. Moreover, the most primitive gabbros are at the base and the top of the section, in contrast to the overall downward progression to more primitive gabbros in Hole 735B (cf. Figs. 15, 23).

\section{Dredges 37 and 32}

Dredges 37 and 32 were conducted on the western and northeastern edges of the massif at 1850 and $1612 \mathrm{~m}$, respectively, on a broad, $24 \mathrm{~km}^{2}$ triangular bench or shelf. They both recovered undeformed to weakly foliated (C-P 2.0), equigranular olivine gabbro, an oxide gabbro mylonite, and several weakly cemented oolitic sandstones (Fig. 25e) and bioclastic sandstones. Oolites are formed in shallow, warm (necessary to lower the $\mathrm{CO}_{2}$ content for their formation), wave-agitated water, such as the Bahamas Platform, at generally less than 10 $m$ depth. The presence of these sands therefore demonstrate that a shallow-water beach extended across the shelf, and the absence of intrusive serpentinite and underlying oxide gabbro mylonites, discussed in detail in the next section, show that the shelf formed by erosion of the gabbro massif. Thus, at the time of deposition of the oolites, Atlantis Bank was a $250 \mathrm{~km}^{2}$ island with a $1200 \mathrm{~m}$ peak above sea level.

\section{Northern region summary}

In summary, the northern region exposes gabbros reflecting a variable proximity to the central and distal ends of the Atlantis Bank Gabbro Massif and as well as variable depths below the footwall of the detachment fault. With numerous inliers of sheeted dikes exposed on the detachment footwall, the lower ocean crust exposed on the transform wall extends from the dikegabbro transition to the gabbro-peridotite contact and has a maximum thickness no greater than $\sim 1700 \mathrm{~m}$, which contrasts sharply to the $4-6 \mathrm{~km}$ of lower crust in the classic Penrose ophiolite model (Conference Participants 1972).

Except for the presence of substantial greenschist facies alteration and cataclasites, the northern gabbros closely resemble the upper $500 \mathrm{~m}$ of Hole 735B in terms of mineral composition and deformation; they only lack the most evolved gabbros and the primitive troctolite dikes that are found only in the upper $500 \mathrm{~m}$ of the hole. However, in some ways, they are unique. For example, the Dive 466-467 section is three times as long as the comparable section in Hole $735 \mathrm{~B}$, and instead of a downward progression to less deformed and more primitive gabbros, the least primitive gabbros lie in its central section. Extensive high-temperature crystal-plastic deformation is seen from 1755 to $3375 \mathrm{~m}$, a $1620 \mathrm{~m} \mathrm{sec}-$ tion of intercalated deformed and undeformed gabbros, a feature seen only in the upper half of Hole 735B.

Despite traversing two full sections of the lower crust, the rocks sampled do not include troctolites or dunites with primitive plagioclase and olivine that would represent direct crystallization of parental mantle melts. Our modeling indicates that the northern area gabbros formed from parental liquids that had typically undergone $50 \%$ or more crystallization prior to intrusion. There are no primitive cumulates that are even close to equilibrium with a parental mantle melt. Thus, these sections had to have crystallized from evolved melts that were intruded down-axis from the locus of principal 
magma supply, presumably from the center of the massif, or they were hybridized to evolved compositions through penetrative invasion by late $\mathrm{Fe}$-Ti-rich melts. Dive 646, however, sampled the distal end of the gabbro massif at its northern end, which includes some of the most primitive gabbros sampled over Atlantis Bank. Primitive gabbros are characteristic of small gabbro intrusions, and this section appears to record the waning stage of emplacement of the gabbro massif.

The secondary detachment fault at $32^{\circ} 38^{\prime} \mathrm{S}$ represents a fundamental break that coincides with the end of the major magmatism associated with the Atlantis Bank Gabbro Massif. Immediately north of this fault, there is a relatively small gabbro block sampled by Dredge JR31-12 which was down-dropped on a fault, which is now covered by younger weathered but otherwise unaltered pillow basalts. This gabbro, exposed in a landslip scar along the south wall of the northern east-west ridge, extends only a short distance towards the transform. Along strike, Dive 6K-655 traversed a fragment of the primary detachment fault footwall down-dropped on the $32^{\circ} 38 \mathrm{~N}$ fault. It recovered a complex assemblage of small oxide and olivine gabbro apophyses extending from the gabbro massif and intruding coarse granular peridotites cut by numerous diabase dikes. A straightforward interpretation of these results is that the gabbro block represents an abrupt reduction in magma flux to the paleo-ridge axis that resulted in only a small central magmatic complex, which was then covered by pillow lavas associated with a small southward ridge jump.

A lower magma supply implies a stronger lithosphere, which explains the failure of the primary detachment fault which locked at this point, and the formation of the secondary detachment fault within the older core complex (south of the primary detachment fault termination). However, in the absence of a significant change in the plagioclase anorthite content at a given augite $\mathrm{Mg \#} \mathrm{compared} \mathrm{to} \mathrm{the} \mathrm{western} \mathrm{and} \mathrm{eastern} \mathrm{region} \mathrm{gab-}$ bros (e.g., Meyer et al. 1989) (Fig. 17), the lower magma supply is unlikely to have been due to a change in mantle temperature, but rather to a major change in mantle fertility at the base of the underlying mantle melting column beneath the paleo-ridge axis.

The saddle between the paleo axial neovolcanic ridge and the main gabbro massif extends as a valley to both the east and the west. This must represent the location of the secondary fault termination, where gabbro in the footwall is in contact with the pillow lavas in the hanging wall. As exposed in a large landslip headwall west of the saddle, the nature of the termination changes from footwall gabbro against hanging wall volcanic rocks to juxtaposition of mantle peridotite against the gabbro with both footwall and hanging wall locally intruded by small gabbro pods and stringers that were later crosscut by dikes and covered by pillow lavas.

\section{Eastern region summary}

The eastern region comprises the $\sim 25 \mathrm{~km}^{2}$ wave-cut platform at the top of Atlantis Bank and its immediate flanks. It includes the two major north-south, high-angle normal faults on the eastern side of the platform and the intervening eastern bench. The bench has a long northsouth ridge down its axis that is likely an uneroded megamullion structure. This indicates that the bench was down-dropped by the $\sim 600 \mathrm{~m}$ throw on the $57^{\circ} 18^{\prime}$ E high-angle normal fault prior to, or during, uplift of Atlantis Bank to sea level. The wave-cut platform and bench end at the face of the $32^{\circ} 40^{\prime} \mathrm{S}$ detachment fault (Fig. 3). The $57^{\circ} 18^{\prime} \mathrm{E}$ fault does not offset the detachment fault face, but runs farther north for $\sim 2 \mathrm{~km}$, and then hooks to the east for several kilometers before dying out. As neither fault face cuts the other, it would appear that both faults were active concurrently, which is also likely the case for the $57^{\circ} 21^{\prime} \mathrm{E}$ high-angle normal fault.

At its southern end, the platform ends where the detachment footwall is locally preserved on a gently domed, north-south-trending spine that exposes weathered pillow lava and serpentinite fault gouge. Weathered, but otherwise unaltered, pillow basalts were also observed and sampled by ROV, submersible, and dredging at several other locations in the eastern area where the detachment footwall is preserved. These contain fresh olivine microphenocrysts attesting to their lack of hydrothermal alteration, which characterizes all the remaining seafloor assemblages, and thus, these are taken as rafted hanging wall debris.

\section{Platform survey}

The top of the platform has a fringing, lithified, bioclastic carbonate sand beach that covers the outcrop and cements in the beach cobbles that locally project from it. The central platform, consists of hummocky outcrops consisting of small sea stacks and bedrock that expose deeply weathered and pitted, highly deformed, flat-lying, foliated mylonitized gabbro with enclaves of less deformed material (Fig. 27a, b). Diabase dikes were imaged locally crosscutting the gabbros in these enclaves (Fig. 27c) and were drilled at two locations (Fig. 5). Greenschist facies, cataclastic diabase and retrograded gabbro breccias in the detachment fault brittle zone, have been largely eroded off the top of the platform but are common in seafloor samples on the flanks of the platform and lying on the detachment fault footwall.

Assuming a gently domed original structure conformable to that preserved on the spine to the south, $\sim 200 \mathrm{~m}$ were removed by erosion at the center of the platform, 

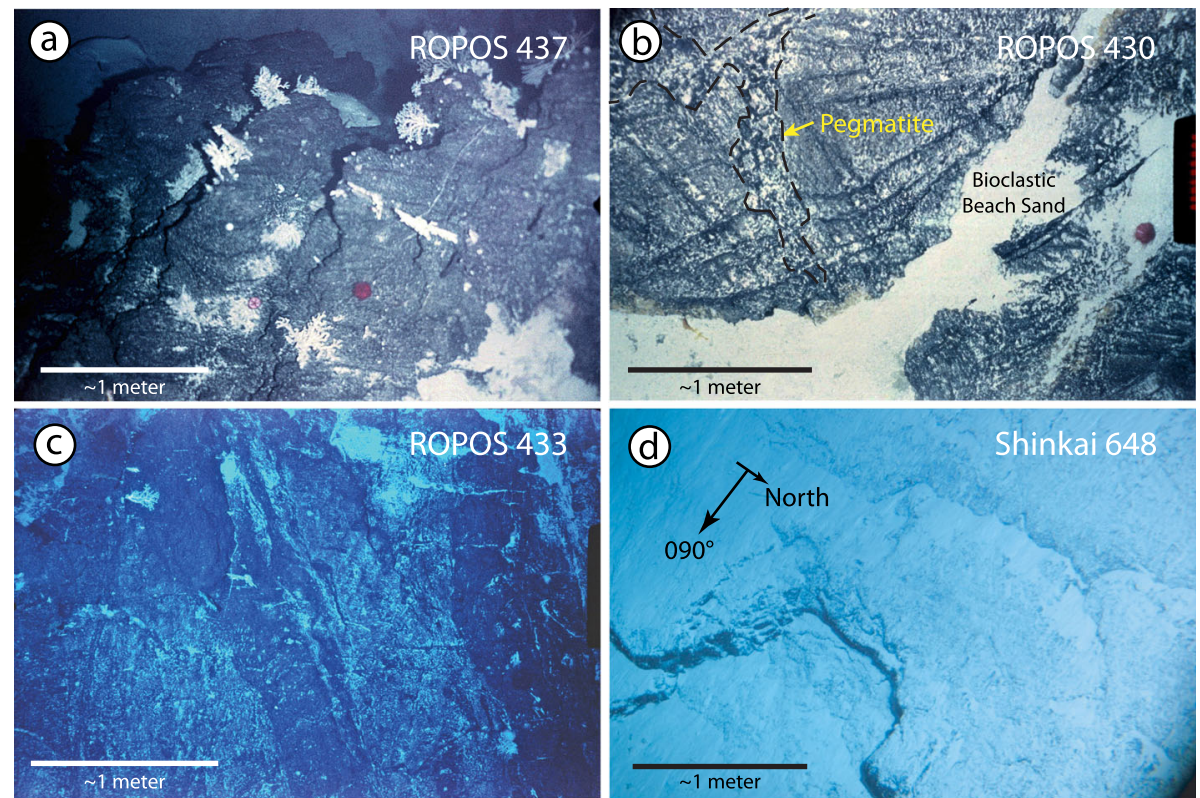

Fig. 27 Seafloor images from the ROPOS ROV and Shinkai 6500 submersible. Panels a to $\mathbf{c}$ are all vertical ROPOS images of the seafloor on the wave-cut platform. The outcrops are all pitted due to preferential erosion of plagioclase and olivine, with white bioclastic sand filling the pits between pyroxene grains. a Dive 437 image showing heavily weathered and pitted outcrop of flat-lying amphibolite mylonite. b Dive 430 image showing a pegmatite crosscutting a relatively undeformed gabbro enclave with two sub-orthogonal amphibole vein sets on weathered wave-cut outcrops emerging from indurated bioclastic beach sand. c Dive 433 image of sub-parallel dikes crosscutting intercalated gabbros in a relatively undeformed gabbro enclave on weathered sub-horizontal outcrop. d Shinkai 6500 Dive 648 showing the shingle-structured, slickensided and down-dip slickenlined, east-dipping normal fault surface on the lower normal fault on the eastern flank of Atlantis Bank

with progressively less towards its margins where the detachment fault footwall is locally observed. Relicts of the footwall and fault damage zone are found in beach gravels and cobbles cemented by lithified bioclastic limestone dredged from around the flanks of the platform (Fig. 25c). Dredge 34 (Fig. 5) contained polymict beach conglomerates with gabbro, diabase, and serpentine clasts. Many of the clasts are well rounded and include reworked older conglomerate. The conglomerates are found as irregular, flat, Mn-coated crusts, underlain by sands that contain gabbro clasts that are deeply pitted by weathering e.g., Fig. 25c. The gabbros range from oxide to olivine gabbros, and from undeformed to ultramylonite. A count of 197 clasts in a Dredge 34 conglomerate found no basalt, $8.6 \%$ diabase, $3 \%$ serpentinite, and $85 \%$ generic gabbro. Of the latter, those clasts that could be more specifically identified (125) are 75\% olivine gabbro and $25 \%$ oxide gabbro. This demonstrates that serpentinite, also found in a diamond core just off the southern end of the platform (Fig. 5), overlay the platform before erosion.

The platform was extensively drilled with over-the-side diamond rock drills (Fig. 5) and analysis of these constitutes almost our entire mineral data set for the eastern area, though these would appear to be representative of the gabbros sampled there as a whole. Most of these sites are located in the eroded center of the southern half of the platform, whereas Hole 735B is sited on the west side of the platform (Fig. 3) preserving a shallower section than the over-the-side rock drills. The gabbro cores have, ignoring outliers, a more restricted range of mineral compositions (Plagioclase $\mathrm{An}_{39}-\mathrm{An}_{62}$, Cpx Mg\# 65-84) than the northern gabbros (Plagioclase $\mathrm{An}_{33}-\mathrm{An}_{68}, \mathrm{Cpx} \mathrm{Mg \#}$ 60-86) (Fig. 19), with generally more intermediate compositions. This is similar to those sampled by Dives 466-467 (Fig. 26), except that the latter have lower average plagioclase anorthite contents $\left(\mathrm{An}_{46.2 \pm 8.7}\right)$ at a given value of Cpx Mg\#, indicating a more fertile or less melted mantle source composition for the magmas to the north. The platform gabbros have more restricted mineral compositions than those in the northern area, which ranges to both more primitive and less fractionated compositions.

\section{Dive 6K-462}

Dive 6K-462 (Fig. 28) explored the upper part of the north-south-trending, high-angle fault zone situated at $57^{\circ} 19^{\prime} \mathrm{E}$, traversing $3 \mathrm{~km}$ northward between the 1100 and $1200 \mathrm{~m}$ bathymetric contours, and then turned due west upslope $750 \mathrm{~m}$ to the edge of the wave-cut platform. Although much of the slope is sediment covered, Mn-covered bioclastic limestone with a serpentinite chip was sampled near the start of the dive. Mid-traverse, 


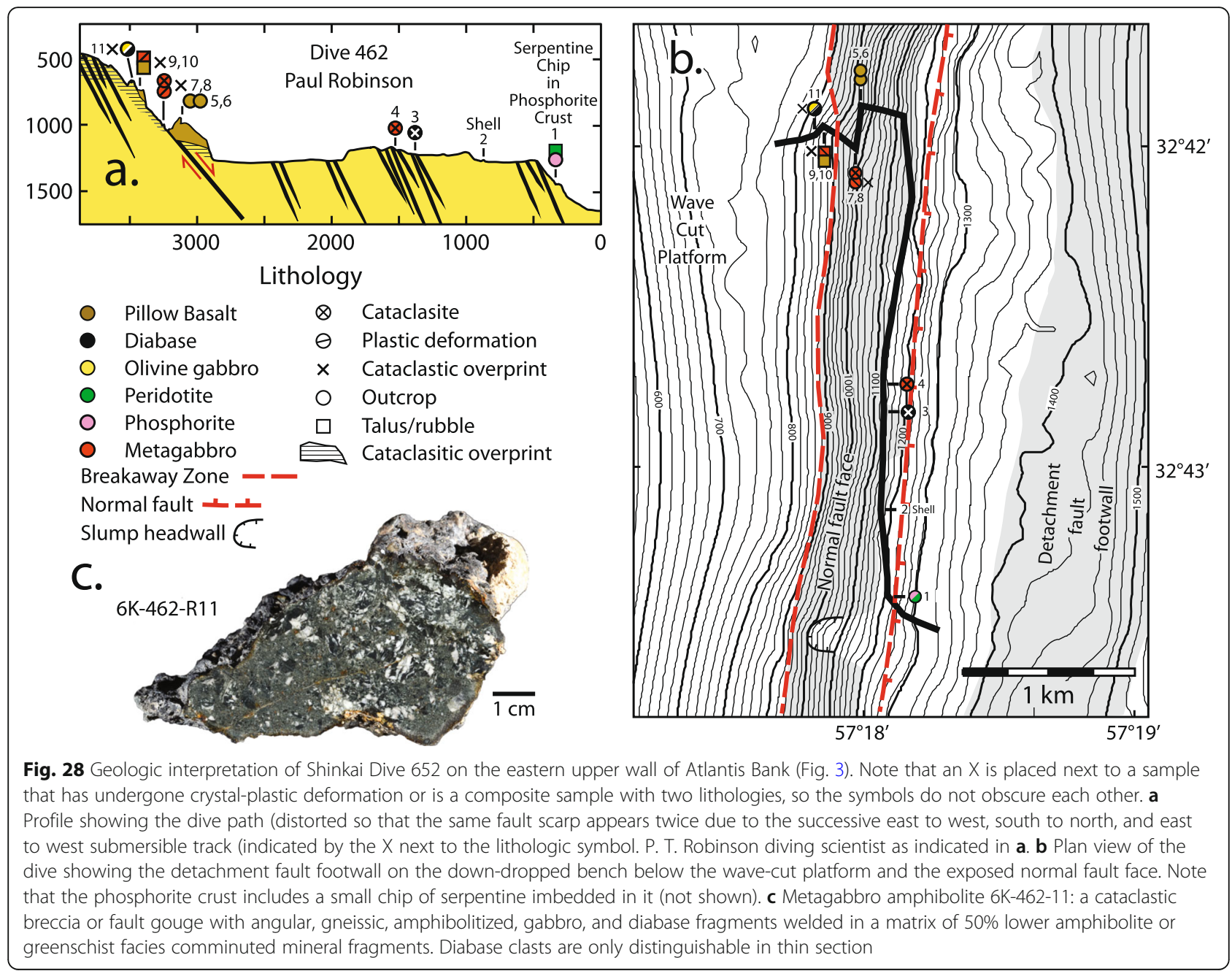

diabase cataclasites were sampled at two localities, whereas upslope on the wall, an outcrop of hanging wall debris was sampled consisting of weathered, but otherwise fresh and intact pillow basalt debris. The dive collected gabbro cataclasites at three locations high on the wall, including several consisting of amphibolite gneiss clasts (Fig. 28c). The cataclasites have all undergone greenschist facies metamorphism and thus represent a fault brittle damage zone and associated hydrothermal alteration.

\section{Dives 648 and 653}

Dives 648 and 653 traversed from largely gabbro outcrop into sub-parallel dike sets with intervening gabbro screens at the breakaway zone (Fig. 30). The transition from gabbro to mostly dikes based on sample appears to be $\sim 500 \mathrm{~m}$ thick. At $1748 \mathrm{~m}$ at the top of the fault face, on the lip of the Eastern Bench, a $\sim 30-\mathrm{cm}$ indurated sand and cobble layer sits on a smooth gently east-dipping bare rock surface, overlain by an $\sim 30 \mathrm{~mm}$ indurated layer of pure white sand (oolitic?), and then another indurated layer of sand and cobbles, locally covered by a thin manganese crust. sit on basement outcrop consisting of sheeted dikes with minor intervening gabbro screens (Fig. 30c). The conglomerate overlying the sand consists of moderately angular cobbles and suggests that most likely slip on the normal fault to the west caused considerable debris to be shed off it onto the bench (Fig. 30a).

Dive 6K-648 collected a single coarse-grained, undeformed troctolite with Mg\# 88-90 Cpx (Fig. 32a). Abyssal peridotite Cpx generally has $\mathrm{Mg} \# \sim 91.4$ (Dick 1989), and this sample could easily be a cumulate from a melt not far from equilibrium with mantle olivine. This is the only troctolite found in the seafloor sample suite suite, and as such, provides the only evidence for highlevel storage or transport of a MORB parental magma in the gabbro massif other than the series of troctolite dikes found in the upper $500 \mathrm{~m}$ of Hole 735B. In this light, it is worth noting that the three peridotites collected in the eastern region, include two dunites, and one additional dunite in contact with a lherzolitic peridotite. 


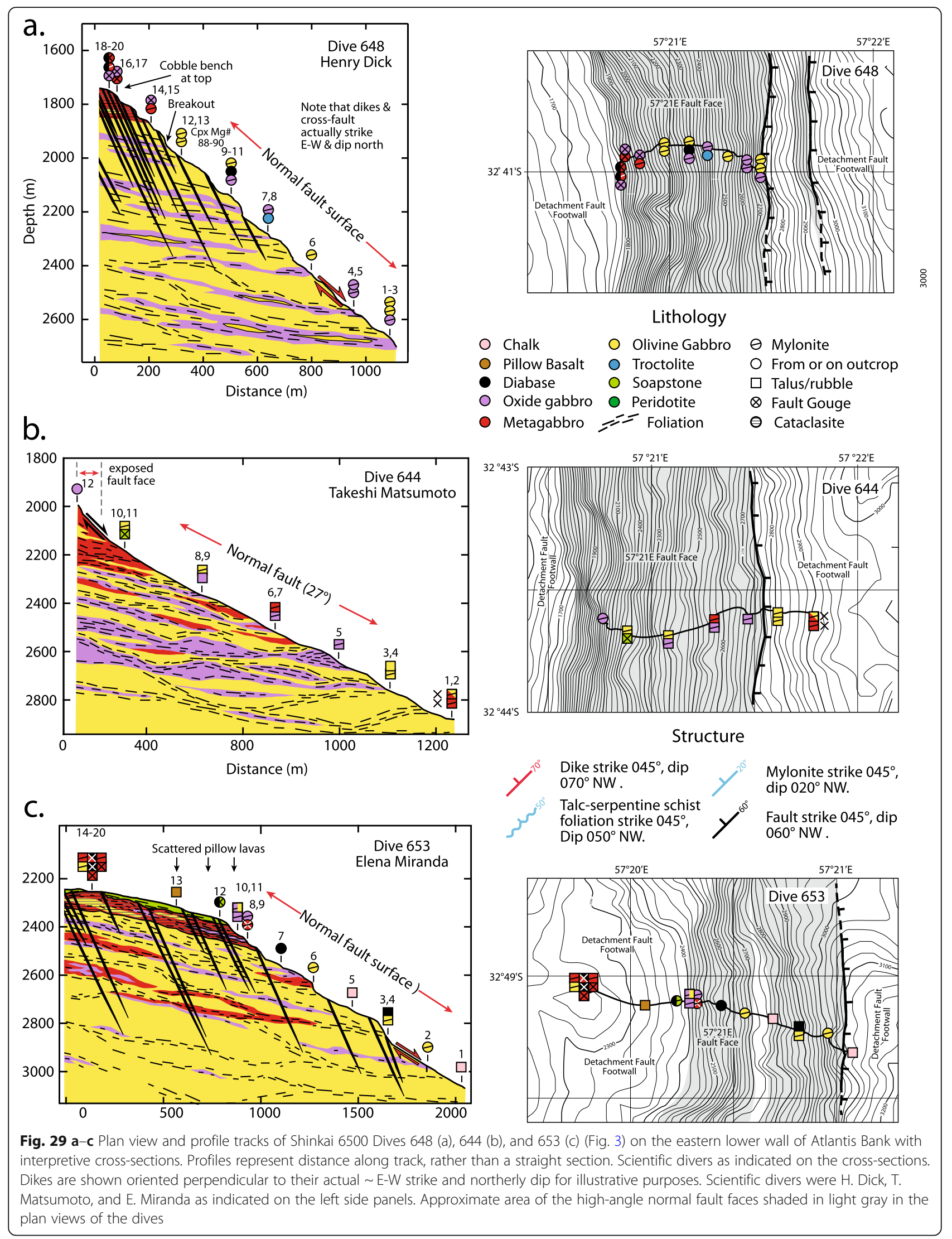



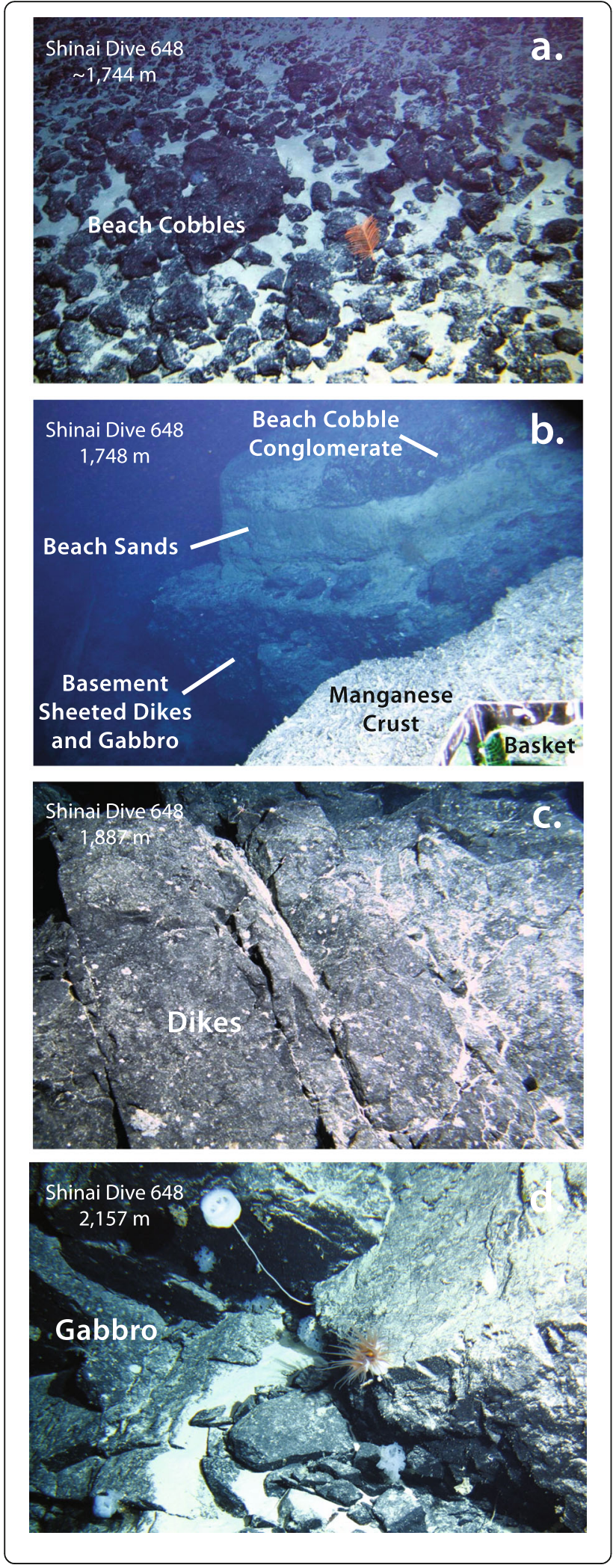

Fig. 30 Digital images taken on Shinkai Dive 648 up the normal fault face at $57^{\circ} 21^{\prime} \mathrm{E}$ on the eastern flank of Atlantis Bank. a Beach cobbles on gently-dipping $12^{\circ}$ slope on the Eastern Shelf. $\mathbf{b}$ Lip of the Eastern Shelf showing possible beach conglomerate or debris fan overlying sands and basement sheeted dikes and subordinate gabbro. c East-west trending sheeted dikes exposed in a breakout on the normal fault face. $\mathbf{d}$ Massive gabbro outcrop with various benthic critters in an east-facing breakout on the normal fault face

Dive 653 dive (Fig. 29c) sampled an outcrop of talcserpentine gouge intruded by diabase (Fig. 31a) on the lip of the north-south-trending bench. The protolith of the serpentinite, based on mineral pseudomorphs, was a harzburgite or lherzolite. The gouge is now largely talc, likely due to release of silica from the diabase during hydrothermal alteration. Further along the bench a greenschist facies, polymict diabase-gabbro cataclasite was also sampled indicating the presence of a brittle fault damage zone (Fig. 31b). These observations appear to confirm that the bench is an uneroded, downdropped section of the primary detachment footwall.

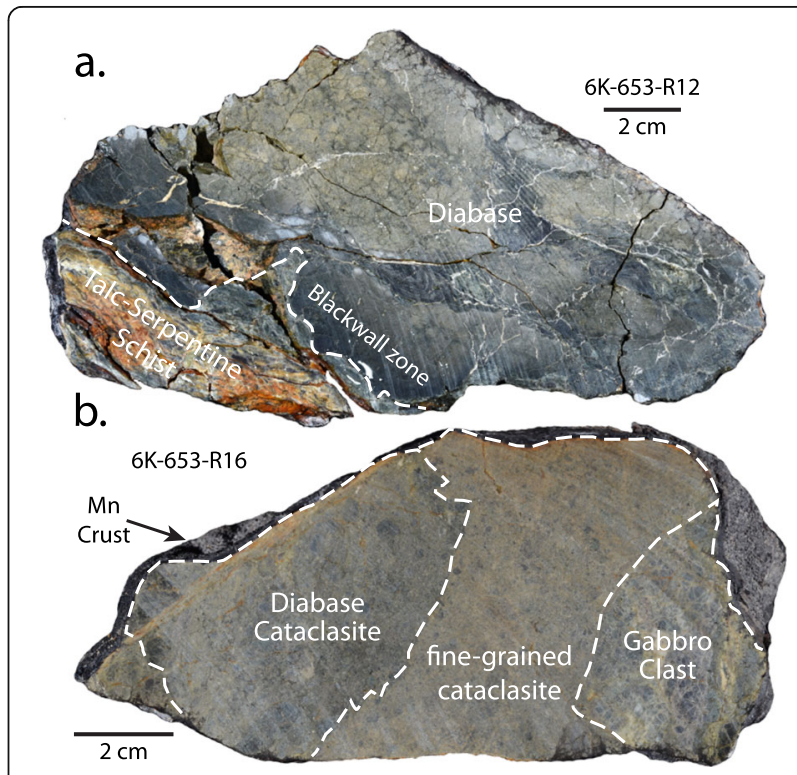

Fig. 31 Selected samples collected on Shinkai 6500 Dive 653 on the $57^{\circ} 21^{\prime}$ E Fault Face (Fig. 29c). a Heavily fractured, chloritized, greenschist facies diabase in contact with talc-serpentine schist from the fault gouge at the lip of the bench above the high-angle normal fault at $57^{\circ} 22^{\prime} \mathrm{E}$. Note "blackwall" zone in the dike margin due to reaction with the enclosing sheared serpentinite. Apparent boudinage of the diabase may actually reflect the development of a dike-finger structure due to melt intrusion approximately perpendicular to the cut face of the sample through sheared serpentinite. b Polymict cataclasite with coarse gabbro and diabase clasts in a fine-grained matrix from detachment fault footwall on the bench above the normal fault. Note the thin 1-3 mm manganese crust on the upper side of the sample 


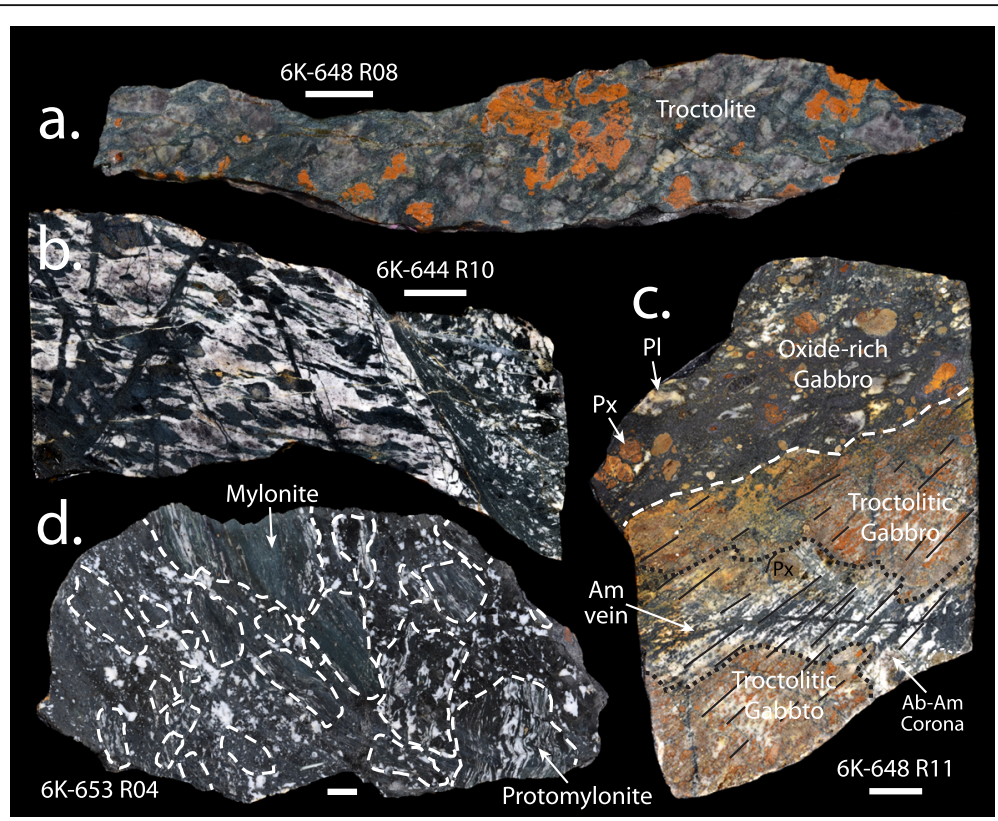

Fig. 32 Selected samples collected from the eastern Atlantis Bank high-angle normal fault face at 57 21' E (Fig. 29): a Coarse-grained spinelbearing troctolite with Mg\# 88-90 augite. Approximately 50\% of the olivine is replaced by actinolite and chlorite, and the rest by bright orange clay. b Amphibolite facies olivine gabbro with near 100\% replacement of mafic minerals by undeformed black hornblende. c Porphyroclastic oxide-rich gabbro in an oxide-rich shear zone crosscutting a foliated troctolitic gabbro. Foliation traced by thin black lines whereas the contact is traced by the long-dashed white line. There is a $\sim 2 \mathrm{~cm}$-wide amphibole-albite alteration halo in the troctolitic gabbro around a crosscutting millimeter-thick black amphibole vein offsetting the foliation by $\sim 1-2 \mathrm{~mm}$. The olivine gabbro augite is the light gray to silvery mineral whereas the olivine is oxidized to orange clay. $\mathbf{d}$ Cataclasite consisting of angular fragments of gabbro amphibolite gneiss, with clasts ranging from protomylonite to mylonite, outlined by dashed white lines, in an undeformed recrystallized matrix of fine- to medium-grained amphibole and plagioclase replacing gabbro cataclasite from near the foot of the eastern, high-angle, normal fault face

\section{Dive 644}

Dive 644 (Fig. 29b) only reached outcrop at the end of the dive and was not high enough to sample either the dike-gabbro transition or the overlying detachment fault footwall. With such a steep slope, it is not certain that the Dive 644 samples represent the local outcrop. Two samples from the foot of the dive were thought to represent deformed gabbro intruded and partially. Assimilated by diabase (6K-644 R01 and R02), but instead proved to represent fluidized cataclasites intruding the gabbro. Dive 644 also collected a large cobble of highly sheared talc-serpentine schist on the $57^{\circ} 21^{\prime} \mathrm{E}$ fault face at 2194 m (6K-644 R11), but with spinel dunite enclaves, rather than lherzolite. This, was sampled sitting on outcrop, and most likely represents fault gouge from the detachment fault damage zone exposed at the top of the bench.

\section{Dives 648, 644 and 653 Petrology}

The 52 samples collected on Dives 648, 644, and 653 include 11 diabase and 40 gabbro, 11 of which were identifiable as olivine gabbro and 9 as oxide gabbro. Dive 6K648 collected a single coarse-grained, undeformed troctolite with Mg\# 88-90 Cpx (Fig. 32a). Abyssal peridotite Cpx generally has $\mathrm{Mg} \#$ 91.4 (Dick 1989), and this sample could easily be a cumulate from a melt not far from equilibrium with mantle olivine. This is the only troctolite found in the seafloor suite, and as such, provides the only evidence for high-level storage or transport of a MORB parental magma in the gabbro massif other than the series of troctolite dikes found in the upper $500 \mathrm{~m}$ of Hole 735B. In this light, it is worth noting that the three peridotites collected in the eastern region, include two dunites, and one additional dunite in contact with a lherzolitic peridotite.

The majority of the gabbros are heavily altered to the amphibolite facies (e.g., Fig. 32b), and underwent prealteration, anhydrous crystal-plastic deformation. The oxide gabbros have an average crystal-plastic deformation grade of $3.4( \pm 1.4)$, whereas the olivine gabbros, as in Hole 735B, are less deformed (average C-P $=2.4 \pm$ 1.1). Generic gabbro, which includes those rocks too altered or deformed to determine a specific protolith, has an average grade of C-P 3.2 (protomylonite).

Unlike the ODP and IODP cores, many of the samples from the upper portion of these dives have undergone extensive cataclasis and alteration under a range of conditions from lower to middle amphibolite facies down through greenschist facies and lower. The average cataclastic deformation grade is $0.9 \pm 0.9$ for the oxide 
gabbros, $1.4 \pm 1.0$ for the olivine gabbros, and $2.4 \pm 1.9$ for the generic gabbros. The cataclasites include monomict gabbro and diabase breccias, as well as polymict diabase-gabbro breccias (Fig. 31b).

\section{Eastern region summary}

The high proportion of oxide gabbros, intense crystalplastic deformation, and extensive amphibolite facies alteration in Dives 642, 648, 644, and 653, and the associated dredge samples from the eastern high-angle normal fault faces are similar to those anticipated within $500-700 \mathrm{~m}$ of the detachment fault footwall based on the ODP and IODP drill holes, and thus extends that stratigraphy some $7.5 \mathrm{~km}$ farther to the east.

Sample 6K-648 R11 (Fig. 32c), in effect, sums up the history of the high-level Atlantis Bank gabbros from initial intrusion at depth through their passage into the brittle-ductile transition. This sample, after initial crystallization at depth from a moderately differentiated melt, was an olivine-rich gabbro cumulate with $\sim 60 \%$ plagioclase, $25 \% \mathrm{Cpx}$, and $15 \%$ olivine. It then underwent substantial high-temperature, anhydrous crystalplastic deformation, producing a marked foliation that curved into the principle plane of a ductile shear zone. Fe-Ti-rich liquids moving by permeable flow up through the gabbro due to compaction were drawn into the shear zone, where they reacted out most of the plagioclase and olivine at its center, precipitated the massive oxide, and eroded the foliation at its margins. This left a residue of $\sim 25 \%$ Cpx porphyroclasts imbedded in $\sim 60 \%$ massive Fe-Ti oxide, almost no olivine, and $\sim 15 \%$ plagioclase in sharp contact with the remaining olivine gabbro. With continued uplift, crystal-plastic deformation ended as the sample passed through the brittle-ductile transition into the zone of dike intrusion. There, a crack network formed, bringing high-temperature hydrothermal fluids into the gabbro. These formed a network of black amphibole veins, with a broad corona of albite and black amphibole around the most prominent vein, replaced the primary olivine gabbro mineralogy, and pseudomorphed the crystal-plastic foliation.

The ubiquitous amphibolite gneisses (e.g., Fig. 32b, d) found in the upper gabbros must have formed due to similar, but more pervasive, static hydrothermal circulation, because the black amphibole in these is itself generally undeformed. The amphibolite cataclasites sampled from the foot of the eastern normal fault face on Dives 644 and 653 (e.g., Fig. 32) also provide direct evidence of this earlier, deep, hydrothermal circulation. This process is undoubtedly the source of much of the fluids, sulfur, and metals producing the large sulfide deposits and black smokers at oceanic core complexes.

Finally, a notable feature of the eastern region is the concentration of cataclasites in the uppermost sections of Dives 642, 648, and 653, which are virtually absent in the diamond drill cores on the wave-cut platform due to erosion. This fault gouge appears to be associated with the primary detachment footwall, representing cataclasites formed in the brittle damage zone where the fault was localized prior to exposure on the seafloor.

\section{The western region}

This region ranges from the eroded western flank of the wave-cut platform downslope to where a broad expanse of the original primary detachment fault footwall slopes down to the floor of the transform. In the northwest corner, the large exposure of massive gabbro traversed by Shinkai 6500 Dives 467 and 466 on the northern transform wall progressively pinches out to the south, disappearing where the thin veneer of talc-serpentine schist on the detachment footwall meets mantle outcrop on the lower transform wall. The detachment footwall and brittle fault damage zone, largely eroded away to the north, is well exposed here revealing a near-continuous sheet of talc-serpentine schist and oxide gabbro mylonites that likely once extended over most of the core complex. In the southeast corner of the western area, the slope up to the wave-cut platform is progressively eroded to expose the full fault damage zone now eroded off the platform.

\section{Dive 6K-458}

Dive $6 \mathrm{~K}-458$ (Fig. 34) started at $\sim 4920 \mathrm{~m}$ on the sedimented floor of the transform, encountering statically serpentinized, porphyroclastic lherzolite float at $4900 \mathrm{~m}$, statically serpentinized, protogranular lherzolite in outcrop at $4766 \mathrm{~m}$ and weakly foliated, porphyroclastic lherzolite at 4609. It then passed up a break slope at $4490 \mathrm{~m}$, sampling moderate to intensely deformed oxide gabbronorite (C-P 2-3) in float at 4434 and again at 4195 where the dive ended at the foot of a steep wall. Although the contact is covered by sediment and float, the samples are compositionally and texturally consistent with a simple intrusive contact between highly evolved, oxide gabbros and mantle peridotite.

\section{Dive 6K-459}

Dive 6K-459 (Fig. 34) landed on peridotite mylonite on the detachment footwall and then traversed over oxide gabbro mylonites, protomylonites, and a few enclaves of less deformed oxide gabbro just below the shoulder of the headwall of a large landslip where it cuts the detachment fault surface. The dive then went up the headwall back onto the detachment footwall where it encountered a massive sub-horizontal outcrop of oxide gabbro mylonite and ultramylonite lying in the plane of the detachment footwall. Of 13 gabbros collected, there was only one 


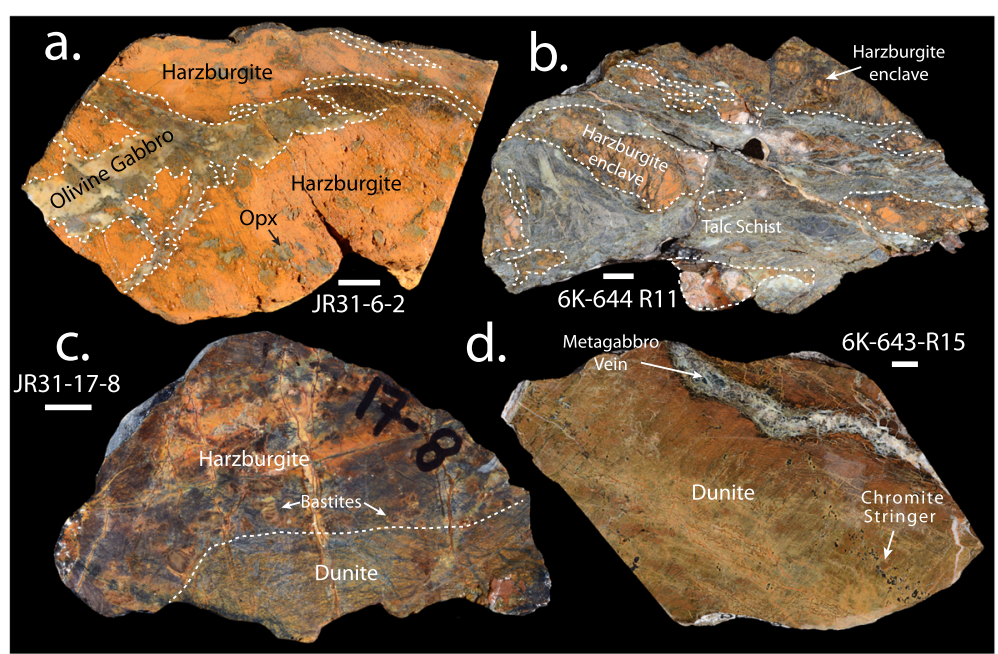

Fig. 33 Pyroxene-poor harzburgite and dunite samples from Atlantis Bank indicative of late-stage melt transport in the shallow mantle. a Deeply weathered, pyroxene-poor harzburgite cut by a stockwork of olivine gabbro veins from Dredge JR31-6 on the northern secondary detachment fault surface (Fig. 3). All olivine is altered to orange clay, whereas the plagioclase in the veins appears to be altered to prehnite and hydrogrossular garnet. b Talc schist with enclaves of deeply weathered, pyroxene-poor harzburgite from the normal fault face on the eastern flank of Atlantis Bank at $57^{\circ} 21^{\prime} \mathrm{E}$ (Fig. 29b). The paragenesis is that of high-temperature fault gouge initially intruded up a shear zone due to formation of talc with infiltration of water into the mantle above serpentine stability field with subsequent serpentinization. c Cobble of massive statically serpentinized harzburgite crosscut by dunite dredged from the intersection of the primary detachment fault with the $57^{\circ} 18^{\prime} \mathrm{E}$ Normal Fault face on the eastern edge of the wave-cut platform (Fig. 3). $\mathbf{d}$ Dunite block with local spinel stringers cut by a metagabbro vein from $46 \mathrm{~m}$ below the gabbro-mantle contact high on the transform wall at 54 (Fig. 44)

undeformed olivine gabbro. At $2647 \mathrm{~m}$ the dive collected semi-consolidated oolitic limestone, the deepest such sample found at Atlantis Bank.

\section{Dredge 28}

Dredge 28 (Fig. 34) sampled a large suite of peridotite mylonites on the transform wall just below and on the detachment surface at the start of Dive 6K-459. Several of the mylonites and protomylonites are essentially identical to those sampled at the beginning of Dive 6K-459. Many of the peridotites are only partially serpentinized and consist in large part of highly weathered olivine turned to orange clay. The nearly uniform, high-grade, crystal-plastic textures (C-P 1.0 to 5.0 , average $3.3 \pm 0.9$ ) of the peridotites indicate anhydrous deformation associated with the earliest stages of faulting of the mantle section. Numerous black, crisscrossing serpentine veins indicate that this phase of alteration was under static conditions, after the intrusion of talc localized faulting to a narrow 1$\mathrm{m}$ zone similar to that found by Kaiko Dive 172, and to what was found where the detachment fault cut massive mantle peridotite at the Kane Megamullion (Dick et al. 2008). Given the gabbro outcrops sampled to the north and south of Dredge 28, and below it at $4700 \mathrm{~m}$ to the west, it would appear that these peridotites represent an inlier of the mantle where the detachment fault rooted across massive peridotite into intruding oxide gabbros, now cut off and isolated from the main peridotite body by the late north-south normal faulting.

\section{Dredge 36}

Dredge 36 (Fig. 3) on the transform wall recovered 3 olivine gabbros, 12 oxide gabbros, 11 metagabbros, a soapstone, and a heavily serpentinized porphyroclastic plagioclase lherzolite. A 5-cm layer of talc schist is in contact with a rodingitized gabbro that is pseudomorphed by talc along the contact (sample JR31 3611). Several of the gabbros are rodingites, calciummetasomatized intrusive bodies formed by chemical exchange with serpentinizing peridotite, and commonly identified by their chalky white appearance due to the presence of massive prehnite and hydrogrossular garnet pseudomorphing plagioclase. Like the Dredge 28 peridotite mylonites, these peridotites likely represent a local inlier of the deeper transform mantle section that was intruded down-axis by the gabbro. This would have occurred prior to faulting and uplift, which then isolated the peridotites high on the transform wall. The high proportion of oxide gabbros to olivine gabbro seems to reflect a general increase in the proportion of the former from north to south along the transform wall as also seen in the results of Dives 458, 459, 172, and 651 (Fig. 34). 


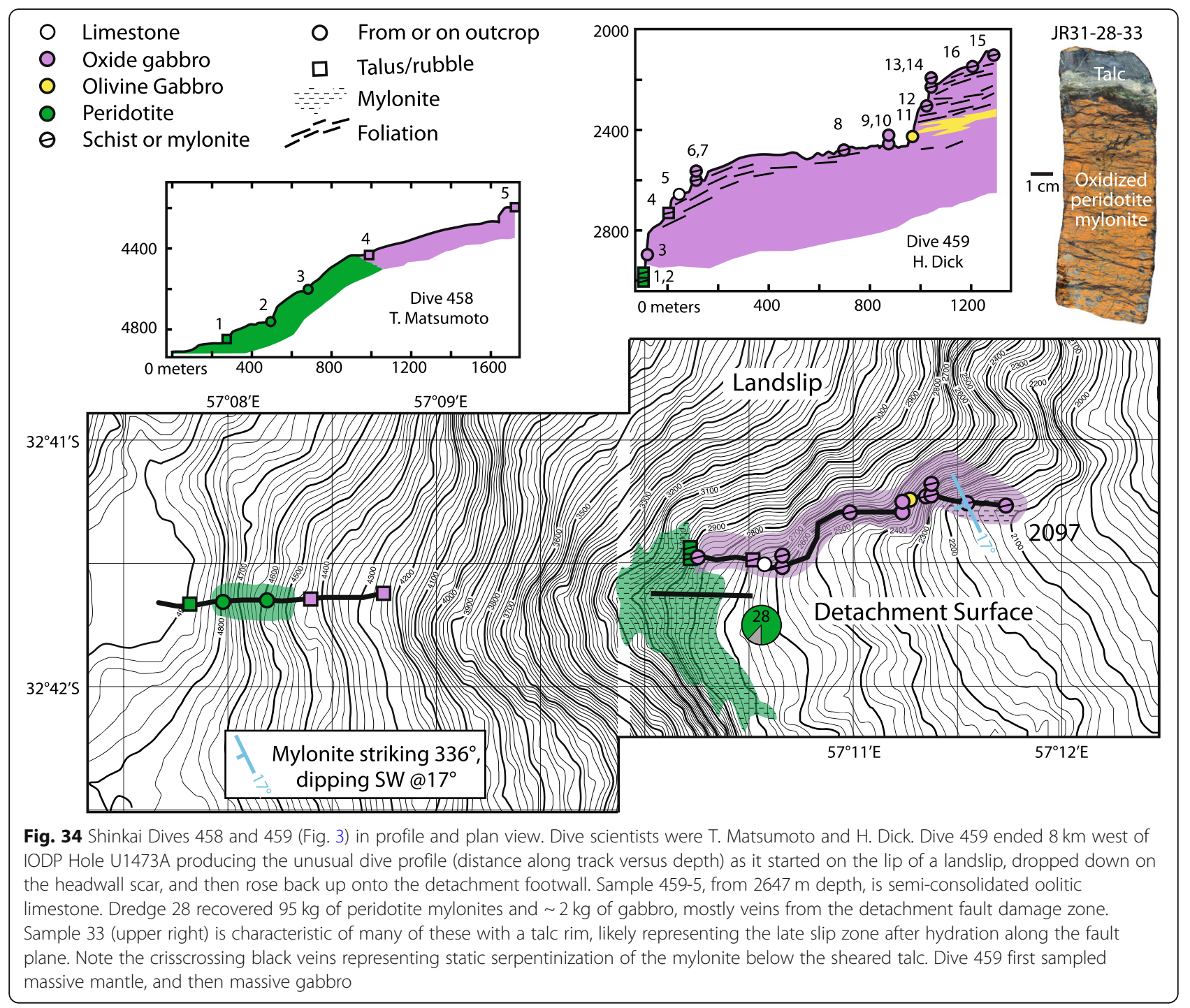

\section{Dive 10K-172}

Figure 35 provides a plan view map and an interpretive cross-section for ROV Kaiko Dive 10K-172 (JAMSTEC MODE 2000 Expedition) (Arai et al. 2001). The dive sampled a massive section of mixed C-P grade 0.0 to 3.0 (average $0.9 \pm 1.1$ ) oxide gabbros up the transform wall and into a large landslip scar. The oxide gabbro section ends with a thick zone of oxide gabbro ultramylonite (CP 5.0) and cataclasite that is overlain by a $1 \mathrm{~m}$-thick talcserpentine schist layer on the detachment fault footwall. Of 25 gabbros collected up the section, only one olivine gabbro was found. Given the apparent imbrication of the steep slope by high-angle, north-south-trending normal faults inferred from several benches crossed by Dive $10 \mathrm{~K}-172$, we interpret the transform wall here as exposing the gabbro massif down to $\sim 500 \mathrm{~m}$ below the detachment footwall.
This thick section contrasts sharply with the Dredge 36 and 33 gabbros exposed on the transform wall to the north and with the upper $500 \mathrm{~m}$ of Holes 735B, 1105A, and U1473A. To the north, the sections consist of olivine gabbro interspersed with subordinate oxide gabbro, whereas to the east the oxide gabbros in the upper portions of the IODP and ODP drill holes are thinner and less massive with major interspersed olivine gabbro horizons.

Dive 10K-172 gabbros show little evidence of their intrusion having been localized along shear zones, unlike many of the gabbros from the massif seen in the deep drill holes and in many of the other seafloor samples. Although this is also the case for some oxide gabbros in the ocean drilling holes on the platform, particularly at depth, the latter generally are minor in volume and seem to represent either local 

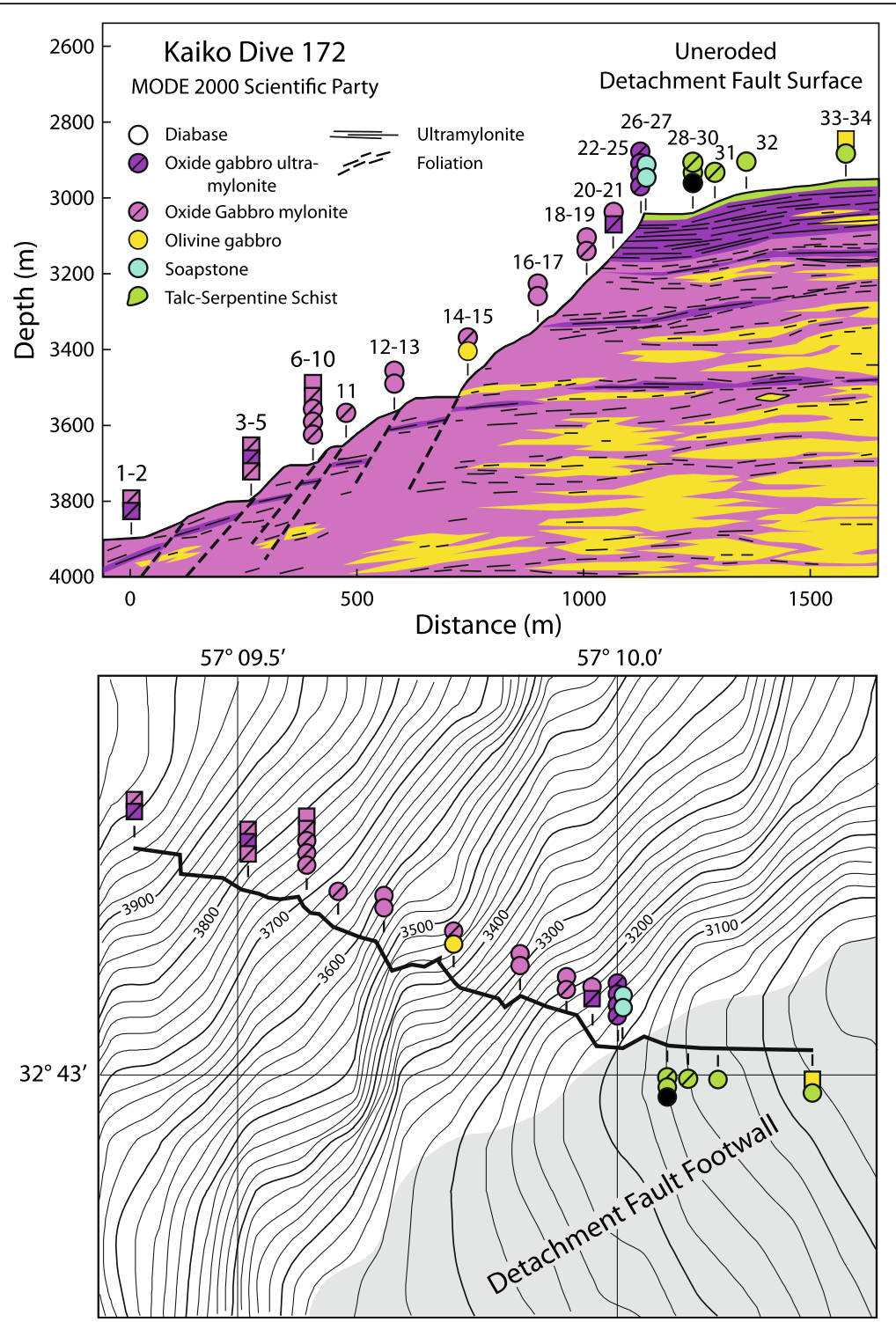

Fig. 35 Interpretative cross-section of Kaiko Dive 172 (Fig. 3) on the western transform wall. Data from Arai et al. (2001). Cross bars on oxide gabbros indicate crystal-plastic deformation grades from 2.5 to 5 (porphyroclastic). An X indicates a cataclasite. Dashed lines are inferred highangle faults or imbricate slump structures. Foliations are represented as dominantly sub-parallel, because they likely strike east-west, although based on drilling they have highly variable dips and often cross cut each other, dipping both north and south. Direct observation, however, indicates that the ultramylonite is conformable to the detachment fault footwall

segregations of late magmatic liquids towards the end of solidification of the cumulates or a local channel for focused flow of late melt up through the section. Noting the highly fractionated character of the gabbros at the contact with the mantle, an origin by vertical migration of compacted melts to a higher level or into a shear zone does not seem viable. Rather, the Dive 10K-172 oxide gabbros have simple magmatic textures and are often undeformed (Fig. 35) consistent with direct intrusion of highly fractionated basaltic melts. Many of the samples are also cut by felsic and dioritic veins, largely undeformed, which likely represent sweat veins of the last late liquids from the crystallizing oxide gabbros.

In comparison to oxide gabbros sampled farther from the transform, these gabbros appear to have undergone only minor synmagmatic or later subsolidus deformation. Although we cannot determine the orientation of the foliations in the seafloor samples collected downslope due to weathering and parting, the uppermost oxide gabbro mylonites observed by ROV Kaiko lie in the plane of the detachment fault surface. These are intensely deformed compared to the rest of the section (c.f., Fig. 36d, e) consistent 


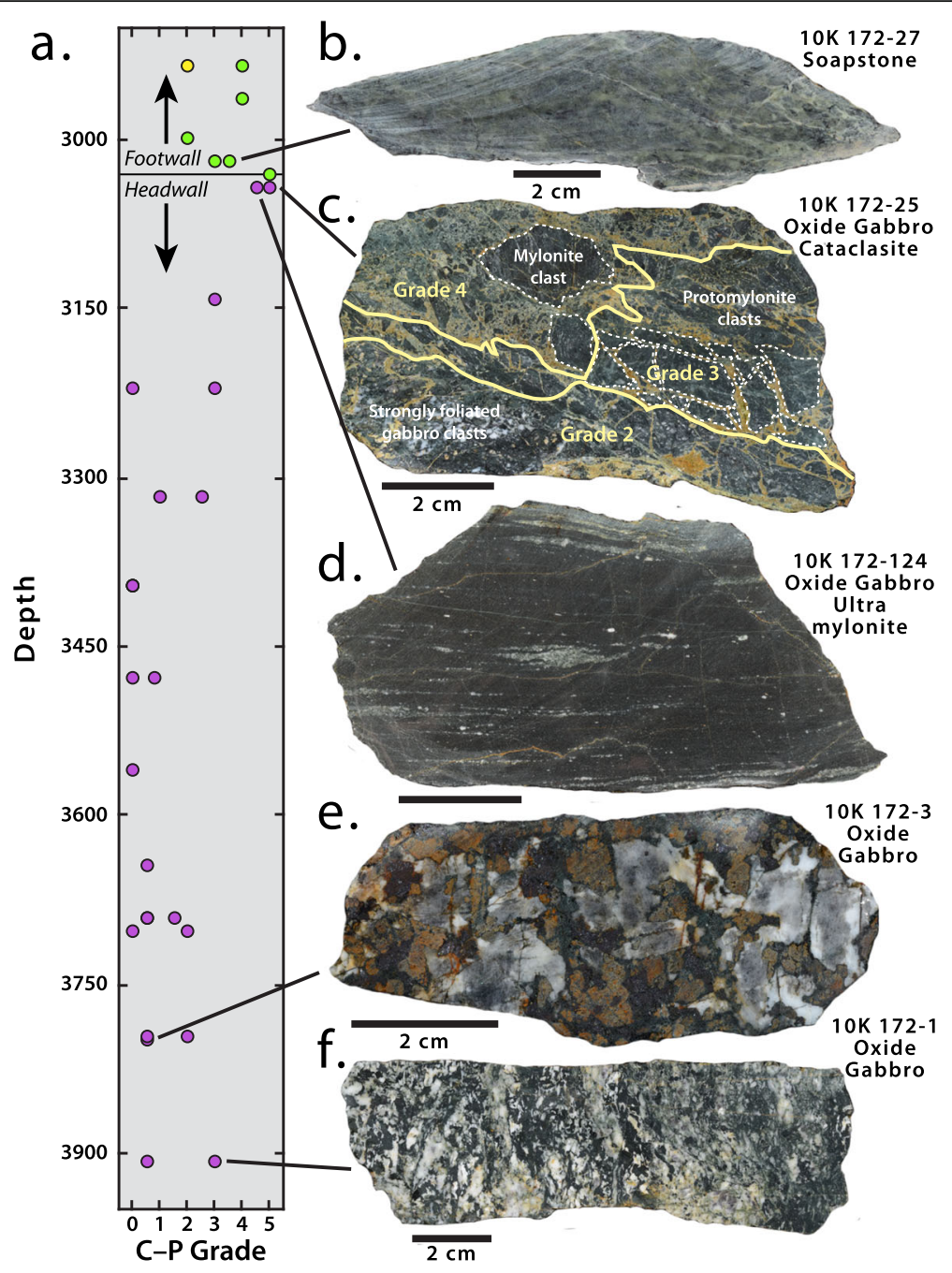

Fig. 36 Representative samples from Kaiko Dive 172 (Fig. 35) showing different crystal-plastic (C-P) deformation grades and lithologies in the fault damage zone overlying massive oxide gabbro. a Crystal-plastic deformation grade versus depth. Solid line separates samples collected from the landslip scar headwall, and lower transform wall from those collected on the gently sloping intact detachment fault footwall. b Lenticular shear polyhedron or phacoid of soapstone. c Oxide gabbro cataclasite grading upward from a Grade 2 brecciated and foliated gabbro, to Grade 3 protocataclasite, and to a Grade 4 cataclasite, all cemented by epidote. Matrix is finely comminuted gabbro and epidote. Solid yellow lines separate brittle deformation zones, and dashed white lines outline mylonite and protomylonite clasts. $\mathbf{d}$ Oxide gabbro ultramylonite immediately below the cataclasite. e Representative oxide gabbro with intact magmatic texture. $\mathbf{f}$ Oxide gabbro protomylonite pseudomorphed by albite and black amphibole with relict Fe-Ti oxides

with their position in the detachment footwall. These reflect intense sub-solidus deformation, which in thin section appears to have been diffusion creep due to a lack of an LPO, whereas the topmost sample of the oxide gabbro consists of an epidote-cemented cataclasite composed of oxide gabbro ultramylonite clasts (Fig. 36c), representing further localization of the detachment fault in the brittle deformation zone at shallow depth.

A $1 \mathrm{~m}$-thick talc-tremolite-serpentine schist layer directly overlies the oxide gabbro ultramylonite and cataclasite (Fig. 36b). Several samples of the schist preserve pseudomorphed peridotite ultramylonites, consistent with percolation of seawater down the detachment fault to the brittle-ductile transition. This then terminated crystal-plastic deformation due to hydrothermal alteration of the peridotite, and the formation of weak serpentine and talc. The talc lubricated the fault zone, and then intruded laterally between the active detachment fault hanging and footwalls to where the fault cut into the gabbro massif away from the transform. With continued faulting, the serpentine and talc assemblage was exposed as a veneer over the gabbro section on the inactive detachment fault footwall.

This talc-serpentine schist veneer extends across a broad region to the northeast, southwest, and east as shown by Dredges 7, 8, 29, and Shinkai Dive 6K-460. Dive 


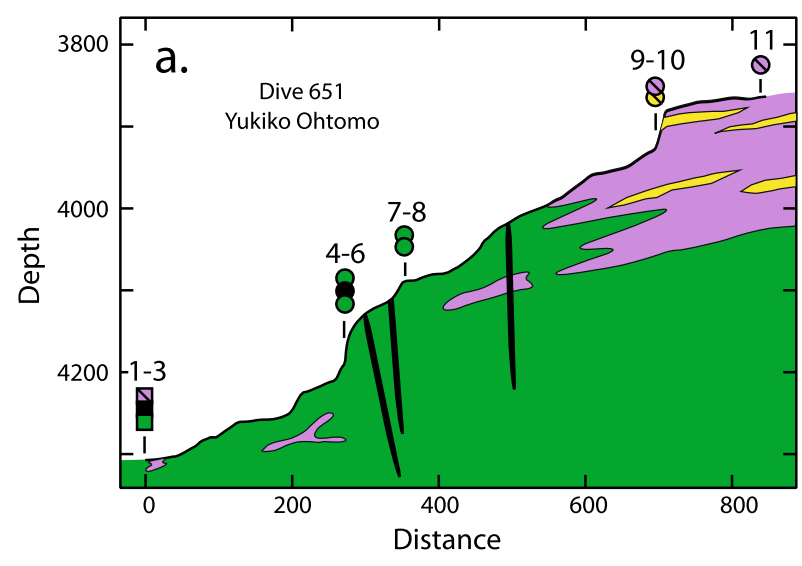

\section{Lithology \\ - Diabase \\ - Oxide gabbro \\ O Gabbro \\ - Peridotite}

Structure

๑ Schist or mylonite

- From or on outcrop

․ Talus/rubble

Slump deposit

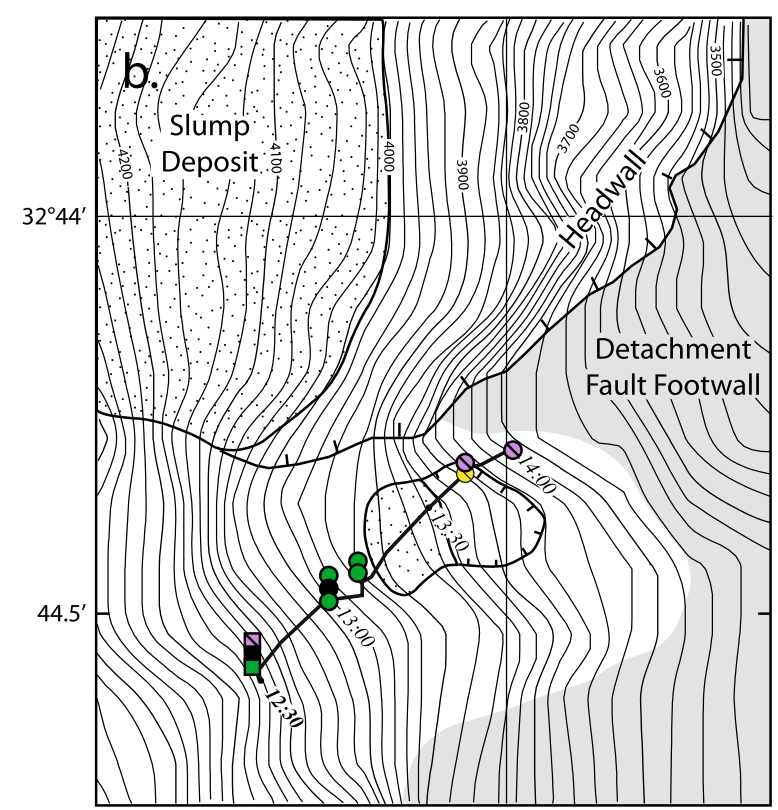

$57^{\circ} 09^{\prime} \mathrm{E}$
C.

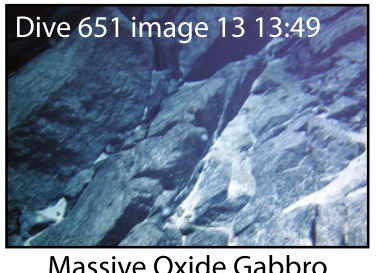

d.

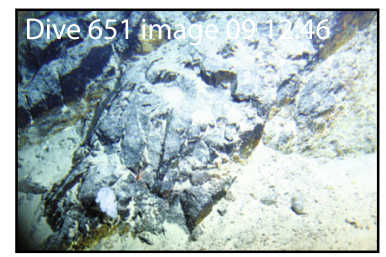

Peridotite

Fig. 37 Shinkai 6500 Dive 651 (Fig. 3) profile and plan view. a Geologic interpretation based on samples, dive observations, and bathymetry. Scientific observer was Yukiko Ohtomo. Highly deformed, C-P grade 2-3 oxide gabbros are intruded into protogranular harzburgite and lherzolite peridotites. b Plan view bathymetry with terrain analysis based on seafloor geomorphology and dive samples. c Massive, jointed oxide gabbro outcrop at $4098 \mathrm{~m}$ depth. $\mathbf{d}$ Irregularly jointed massive serpentinite outcrop at $4214 \mathrm{~m}$ depth

6K-459, and Dredge 13, however, indicate that this veneer is locally discontinuous, and may have been nearly eroded away above $2000 \mathrm{~m}$ depth during uplift of the Bank above sea level. The total extent of the talc-serpentine schist is not known, as shown by the wavy contacts drawn in Fig. 3, though it clearly extends to the south along the contact between the gabbro massif and the mantle section.

\section{Dive 6K-651}

Dive 6K-651 (Fig. 37) traversed a short section of the transform wall from $\sim 4300 \mathrm{~m}$ to $3900 \mathrm{~m}$ depth, just north of where the detachment footwall is projected to pass from massive gabbro to massive peridotite (Fig. 3). It crossed the gabbro-peridotite contact passing over protogranular and weakly foliated lherzolites (C-P $\sim 0.5)$, largely in outcrop (Fig. 37d), into west-dipping, strongly foliated to mylonitic, oxide-olivine and olivine gabbro (Fig. 37c). Based on the textures of the gabbros, we interpret this as an extension of the ultramylonite zone sampled $3 \mathrm{~km}$ to the north by Dive $10 \mathrm{~K}-172$, now directly in contact with the mantle exposed below it on the transform wall. The gabbro massif pinches out on the transform wall near this location, and as at dives 646,466 , and 458 , it represents an intrusive contact with cumulates crystallized from evolved magmas intruded down-axis from the paleo-ridge segment into the transform mantle section. This section was then uplifted $400 \mathrm{~m}$ above the seafloor on a crosscutting north-south- 


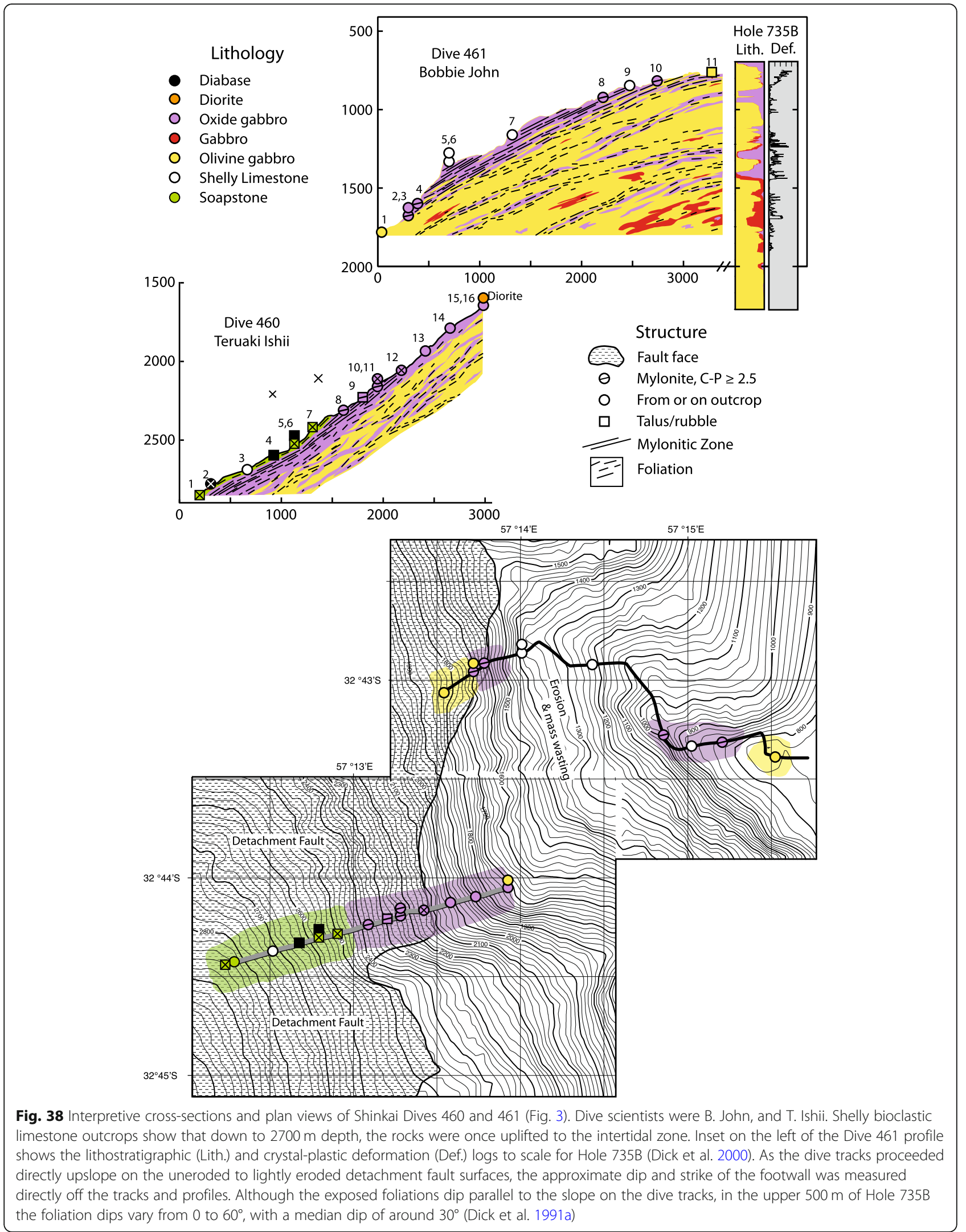




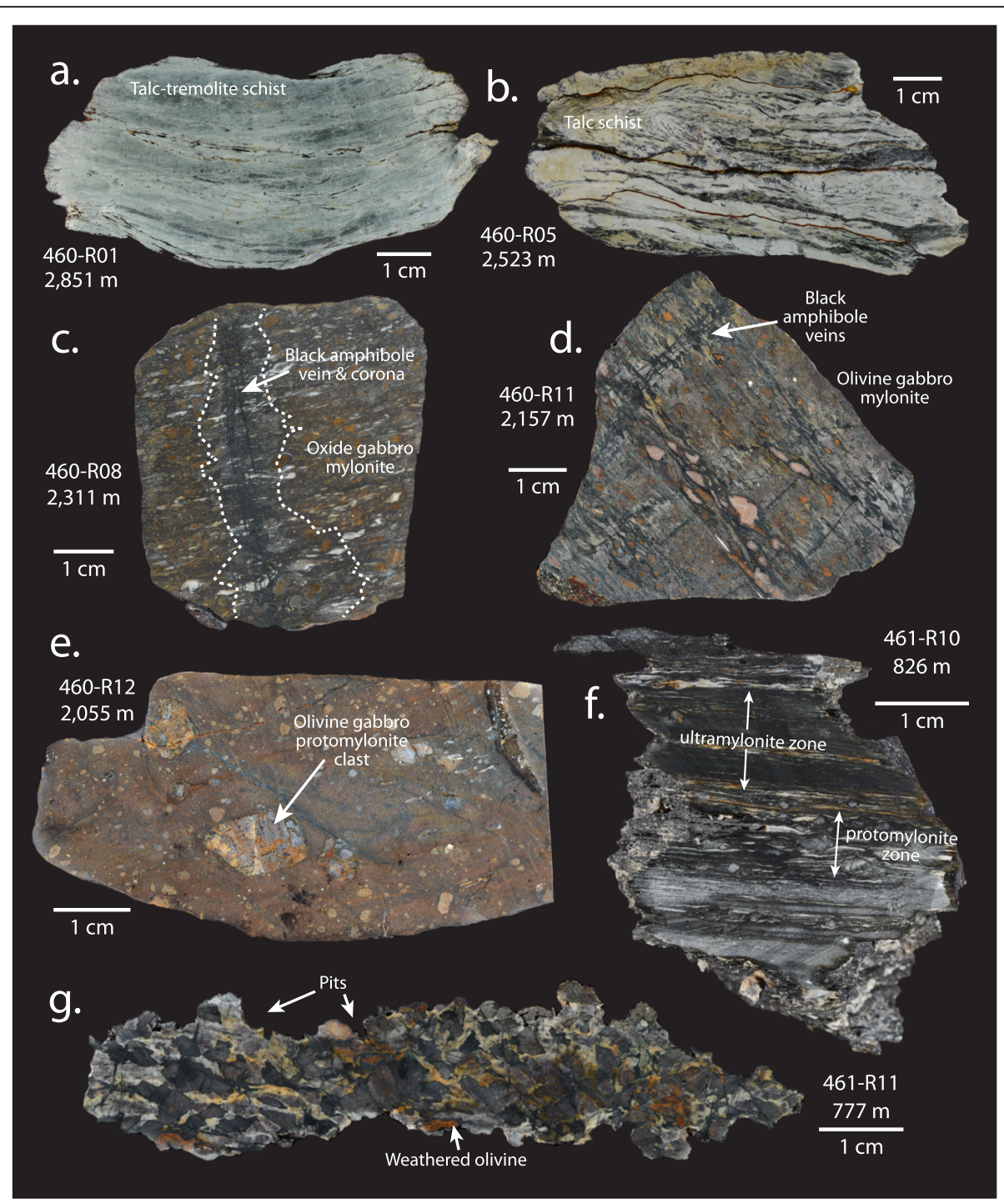

Fig. 39 Representative samples from Shinkai Dives 6K-460 and 6K-461 (Fig. 38): a Talc-tremolite schist. b Talc schist (soapstone). c Partially amphibolitized, oxide gabbro mylonite. Note the centimeter-wide band of orthogonal black amphibole veins and ther albite and black amphibole alteration coronas pseudomorphing the mylonite texture. $\mathbf{d}$ Olivine gabbro, amphibolite mylonite with orthogonal black amphibole veins and albiteamphibole reaction coronas. e Cataclasite or mylonite with clasts of olivine gabbro protomylonite. $\mathbf{f}$ Ultramylonite or ultracataclasite olivine gabbro (or both) with protomylonite layers. The irregular border is due to preferential sub-aerial weathering. $\mathbf{g}$ Deeply weather pitted, amphibolitized, olivine gabbro with weak to moderate crystal-plastic foliation and numerous, late, orthogonal black amphibole veins

trending, normal fault associated with the uplift of Atlantis Bank above sea level.

\section{Dive 6K-460}

Dive 6K-460 (Fig. 38) and 461 together comprise a continuous traverse up the western side of Atlantis Bank from across the eastern edge of the uneroded detachment footwall to the wave-cut platform. Dive 6K-460 traversed east-northeast starting at a depth of $2851 \mathrm{~m}$ across a smooth slope with scattered talus consisting of mixed talc, tremolite, and serpentinite and chlorite schists and soapstones (Fig. 39a, b). A single sample of deeply weathered diabase was collected with soapstone at $2.523 \mathrm{~m}$, which due to its lack of alteration is likely hanging wall debris. The chlorite schist is assumed to have a diabase cataclasite protolith, but it could equally well have been an oxide gabbro. Then, beginning at $2311 \mathrm{~m}$, the dive sampled massive oxide gabbro mylonite at 7 locations, and no olivine gabbro. The lower portion of the dive was clearly over the uneroded detachment fault surface, though only one sample was taken in outcrop. Once it passed out of the serpentinite, it is difficult to ascertain whether the west-facing slope is a fault, or an eroded mullion structure. The continuous oxide gabbro 
outcrop and smooth, gentle uninterrupted slope argue for the latter, with erosion having stripped away the serpentinite and exposed deeper rocks below the footwall. This erosion sequentially exposed first an underlying layer of intensely deformed (C-P 4.5 to 2.5) oxide gabbro mylonites (Fig. 38c, d), and then beginning at $1932 \mathrm{~m}$ gneissic to weakly deformed oxide gabbros (C-P 2), ending in weakly to undeformed (C-P 0.8 to 0 ) equigranular oxide gabbro and an undeformed diorite at $1640 \mathrm{~m}$. Several samples show static partial amphibolitization around thin, black amphibole cracks and veins that have albite-black amphibole coronas of pseudomorphed plagioclase and pyroxene (Fig. 39c, d).

At $2157 \mathrm{~m}$ and again at $2055 \mathrm{~m}$, two unusual mylonites were collected that consist of numerous randomly oriented, rounded pyroxene porphyroclasts and rock clasts in an $~ 80 \%$ aphanitic matrix. Unlike typical gneisses and protomylonites, one sample contains several $\sim 1-2 \mathrm{~cm}$, undeformed, well-rounded gabbro clasts as well as pyroxene augen (Fig. 39e), whereas in the other sample (460R10) the porphyroclasts show only weak crystal-plastic deformation $(\mathrm{C}-\mathrm{P} \sim 1.5)$. Using the gypsum plate in thin section, the matrix appears not to have a lattice preferred orientation (LPO). These rocks, then, could be either high-grade cataclasites or mylonites produced by diffusion creep as neither would have an LPO. On the basis of flowlike textures and microfolds in thin section, it appears that the samples are mylonites.

\section{Dive 6K-461}

Dive 6K-461 started at $1791 \mathrm{~m}$ depth and traversed up a section of moderately deformed (C-P 2.0-3.0) oxide

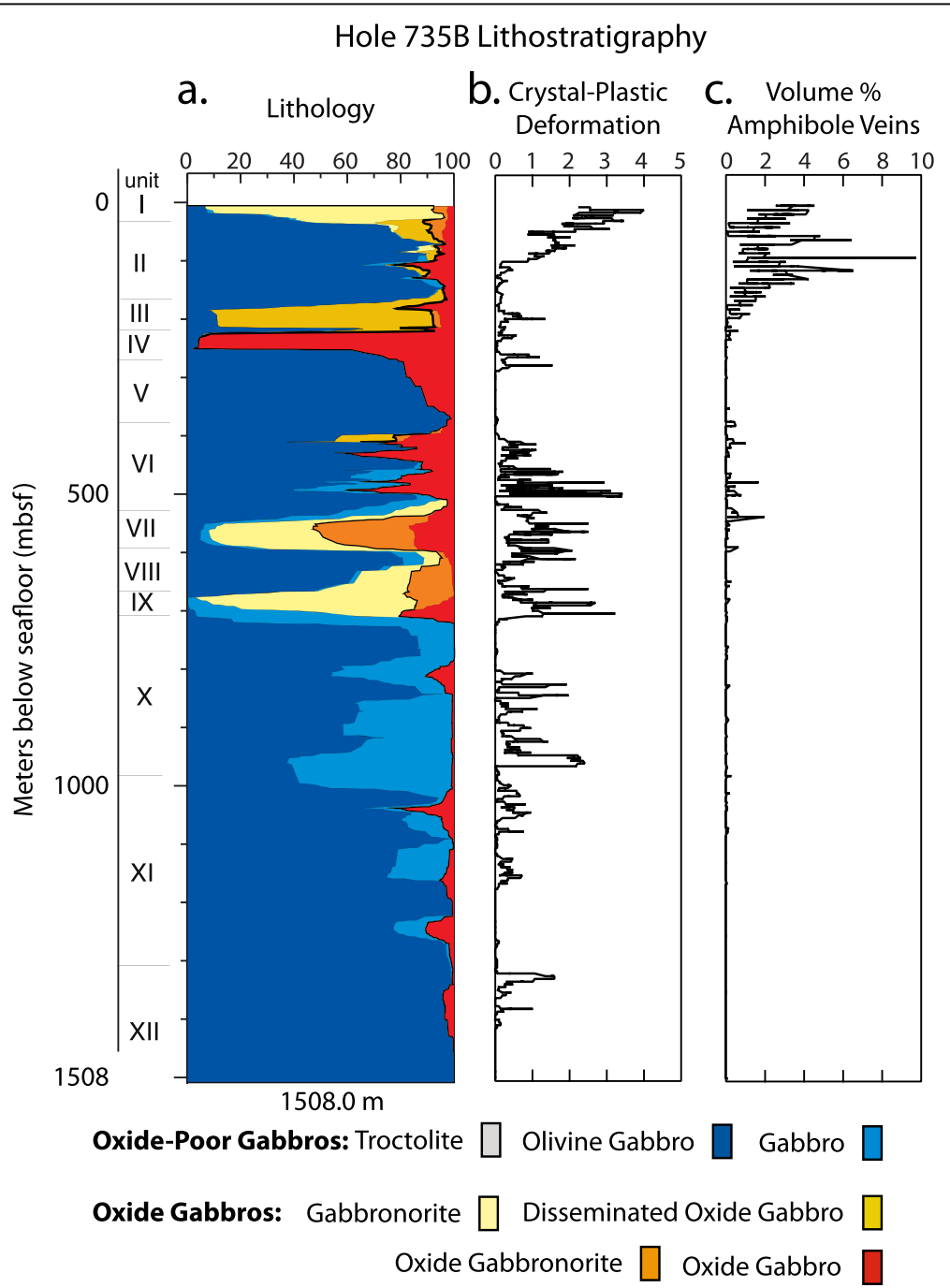

Fig. 40 Hole 735B lithostratigraphic variations: a Relative abundances of igneous rocks averaged over a moving downhole running average of 20 igneous intervals. A total of 952 discrete igneous intervals were described and are included in the running average. Rock names follow the standard IUGS classification with modifiers to indicate oxide abundance. b Crystal-plastic deformation intensity from zero (undeformed) to five (ultramylonite). c Amphibole veins by core percentage averaged over a $2 \mathrm{~m}$ window. Modified from Dick et al. (2000) 
gabbros, but beginning at $1328 \mathrm{~m}$, cemented, bioclastic, carbonate beach sands prevented sampling of the numerous cobbles and boulders strewn across the path of the submersible. At 923 and 826 m mylonitic (C-P 3.0 to 4.5) oxide gabbros, deeply pitted by weathering, and then relatively undeformed (C-P 1.5) coarse-grained olivine gabbros (Fig. 38f, g) were encountered. These samples are all deeply pitted by preferential weathering of plagioclase and olivine, which suggests exposure to a warm, sub-aerial environment for a substantial period of time.

The combined Dive 160-161 traverse provides an opportunity to directly examine what was removed by erosion at Site 735 as Dive 6K-461 ended just short of Hole 735B. The large majority of the samples are intensely deformed (Fig. 39a-f), as is the upper $200 \mathrm{~m}$ of Hole 735B (Fig. 40). The first samples collected on Dive 6K461 contain thin, black amphibole veins, and beginning with sample $461-3$ at $1677 \mathrm{~m}$, the primary igneous and secondary crystal-plastic textures are statically pseudomorphed by black amphibole to the end of the dive (Fig. 39c, d, f, and g, respectively). Black amphibole is generally abundant in the upper $200 \mathrm{~m}$ of Hole 735B both as veins and static pseudomorphs replacing pyroxene and olivine (Fig. 40). Even here, the extent of replacement is fairly erratic, similar to what is seen in the Dive 6K-460461 samples. A correspondence between what was sampled and what was drilled is hardly surprising. At Hole 735B, the first zone of intense crystal-plastic deformation gives way to weakly or undeformed gabbro at $\sim 95 \mathrm{~m}$ below seafloor (mbsf). However, there are undeformed intervals in the upper zone, and deformation is not as intense as in the conformable, oxide gabbro mylonite layer. Our traverse first reached more weakly deformed gabbros only at the end of Dive 6K-460 (samples $460-13$ to 16) at 1934 to $1640 \mathrm{~m}$ depth, before apparently passing back upward into massive oxide gabbros and mylonites (samples 461-1 to 10 ), and then back into weakly deformed, gabbro and olivine gabbro at $777 \mathrm{~m}$ depth (sample 461-11).

\section{Dredge 9}

Dredge 9 was located on a steep slope or ancient sea cliff between 1500 and $1000 \mathrm{~m}$ marking the eastern limit of the western shelf (Figs. 3 and 4). It recovered 4 coarseand 1 medium-grained undeformed, equigranular olivine gabbro that could correspond to a fairly deep level in Hole 735. This suggests, given the irregular topography of the slope, that the shelf below is a wave-cut feature where mass wasting cut deeply into the gabbro massif well below the detachment fault. Two of the gabbros contain An 43-48.2 plagioclase, despite their high olivine contents ( $8-20 \%$ in hand specimen), corresponding to $\sim 80 \%+$ fractionation of our model parent melt.

\section{Western region summary}

The rocks of the western region have the most restricted range of mineral compositions found at Atlantis Bank, which likely reflects the small number of gabbros analyzed given the large range of hand samples from massive oxide to olivine-rich gabbros. The compositions all lie within the field for Hole 735B (Fig. 17c, g). In the northwestern section, the transform wall exposes massive gabbros with inliers of mantle peridotite sampled with massive oxide and subordinate olivine gabbro by Dredge 36, and peridotite mylonites by Dredge 28 . These are believed to be lateral inliers of the transform mantle section enclosed in gabbros intruded down-axis, now isolated by normal faulting. Unlike the peridotite enclaves in the long, $1400 \mathrm{~m}$ Hole 1309D Atlantis Massif gabbro section at the MAR, there is no evidence of the melt-rock reaction there that hybridized the the Hole 1309D peridotites to troctolites (Drouin et al. 2007; Drouin et al. 2009; Drouin et al. 2010). Notably, despite sampling across the gabbro-peridotite contact at two locations, the most primitive gabbro sampled would be in equilibrium with a basaltic magma that had undergone $>60 \%$ fractional crystallization of our model parent melt (Fig. 19).

From north to south along the transform wall, sampling revealed that as the section thins, the percentage of olivine to oxide gabbro decreases rapidly, such that at the location of Kaiko Dive 10K-172, the section consists largely of massive oxide gabbro, much of it unsheared. In contrast, in the upper kilometer of Hole $735 \mathrm{~B}$ and in all $809 \mathrm{~m}$ of Hole U1473A, a good case can be made for localization of late, Fe-Ti-rich ferrobasalt melts migrating upward through the cumulate pile and being localized along high-temperature, crystal-plastic shear zones. There, they hybridized olivine gabbros to oxide gabbros, and created often massive, oxide-rich layers consisting of $60 \%$ or more oxide, with most olivine and plagioclase resorbed by melt-rock reaction during oxide precipitation (e.g., Fig. 32c). Close to the gabbro-mantle contact on the transform wall the Dive 10K 172 samples show no clear association of oxide gabbro and crystal-plastic deformation, except fro the uppermost section near the detachment footwall. Also because the oxide gabbro is present at the base of the section, its formation by upward migation of late interstitial melt is improbable. Eleven of 31 oxide gabbros are essentially undeformed and, excluding the ultramylonites at the top of the section, the average deformation grade is very weak at $0.8 \pm$ $1.4(1 \sigma)$. It appears then that most of the section formed by down-axis intrusion of a highly evolved ferrobasalt magma, reflecting $\geq 70 \%$ fractional crystallization of our parent magma.

The primary detachment fault footwall is well exposed over the western region, and consists of talc-serpentine- 
tremolite schists, with enclaves and pseudomorphs of hightemperature, peridotite ultramylonites within it. Below this is a moderately thick zone of mylonite and ultramylonite oxide gabbro, perhaps as much as $50 \mathrm{~m}$ thick. The upper portion of the mylonite, at least locally, includes cataclasized oxide gabbro mylonite, gabbro, and diabase, suggesting a mixed assemblage of dikes and gabbros that were likely once intercalated in the dike-gabbro transition. The latter is consistent with the many inliers of the dike-gabbro transition seen across the bank. Greenschist facies alteration is seen in the cataclasites (e.g., Fig. 36c), which is volumetrically insignificant in Hole 735B (Dick et al. 1991a; Robinson et al. 1991; Stakes et al. 1991), but quite prominent in Hole U1473B which drilled directly into a late, high-angle, normal fault zone (Dick et al. 2017; MacLeod et al. 2017a).

A close examination of Shinkai 6500 Dives 460 and 461 shows that the entire detachment fault damage zone, including the high-temperature, oxide gabbro mylonites, was removed by erosion at Site 735. Although the detachment fault ultramylonites are conformable with the detachment fault footwall, the foliations in Hole $735 \mathrm{~B}$ are not, instead having an average dip of $35^{\circ}$. There appears to be little overlap between the sections sampled by Dives $6 \mathrm{~K}-460-461$ and Hole 735B, with an overlap of, at most, the upper $\sim 50 \mathrm{~m}$.

\section{The southern region}

The southern region, includes a large area where the detachment fault damage zone has been deeply eroded, with only a few locations where it appears intact at the crest of a small, outward-facing fault scarp at $32^{\circ} 50^{\prime} \mathrm{S}$ (Dives 6K-645, 647), and west of Kaiko Dive 10K-174, where serpentinite obscures the gabbro-peridotite contact along the $2500 \mathrm{~m}$ depth contour. Farther south, the massif is cut by a high-angle, normal fault with $\sim 400 \mathrm{~m}$ throw on the rift valley wall that propagated west across the core complex, which might also represent an imbrication of the detachment fault breakaway zone to the south.

\section{Dredges 39, 40, and 41}

Dredges 39,40 , and 41 sampled a large area of the massif where the detachment fault zone is heavily eroded. In all, 26 oxide gabbros, 6 gabbros and olivine gabbros, and three diabases were recovered. Five of the oxide gabbros have felsic veins, largely trondhjemitic in appearance. Three cataclastic breccias were recovered, two with oxide gabbro clasts, and one with diabase clasts. Overall, crystal-plastic deformation is not intense, averaging C-P $0.9 \pm 0.9(1 \sigma)$, with only one protomylonite. Dredge 41 contained a heavily altered, talcose, shear polyhedron indicating that it had encountered the serpentinite gouge, and a cataclastic diabase breccia from the fault damage zone. However, due to the lack of intense deformation, this region appears to have been eroded down to below the principal fault damage zone.

\section{Dives 6K-645 and 647}

Dives 6 K-645 and 647 were located on a westerly spur at the south end of the north-south spine of Atlantis Bank. Dive 645 traversed east up the nose of the spur, whereas Dive 647 went up a steep outward-facing, degraded, fault face on its southern flank (Fig. 41). Together the dives recovered 31 oxide gabbros, one olivine gabbro, 3 metagabbros, and two diabases. Dive 645 encountered several patches of talcose peridotite and soapstone in the middle and upper part of the slope, whereas 15 of 18 oxide gabbros are mylonites with an average crystalplastic deformation grade of $2.5 \pm 1.7 \quad 1 \sigma$. Thus, it appears that despite erosion in some places, the dive sampled entirely within the detachment fault damage zone. Dive 647, on the other hand, sampled undeformed to weakly deformed oxide gabbros up the fault face to a depth of $1715 \mathrm{~m}$, and then sampled mylonites at 1715 and $1513 \mathrm{~m}$, crudely constraining the oxide gabbro mylonite layer in the detachment footwall to $\sim 200 \mathrm{~m}$ at this location. As at the other localities close to the detachment footwall, oxide gabbro predominates throughout this section, with the continuous sampling of oxide gabbro mylonite up the nose of the spur indicating that unlike crystal-plastic foliations in the oxide gabbro in Hole $735 \mathrm{~B}$, these mylonites are conformable to the detachment footwall as at the other footwall dive locations.

\section{Dredge 30}

Dredge RC27-9-30 was conducted mid slope by the RV Robert Conrad Cruise 27, Leg 9 at $4500 \mathrm{~m}$ depth, roughly $1 \mathrm{~km}$ below and $3 \mathrm{~km}$ west of the inferred gabbro-mantle contact. It recovered 2 olivine gabbros and a metagabbro, 37 lherzolites, 4 harzburgites, and 32 generic peridotites. Twelve of the peridotites contain small metagabbro veins, from 1 to $2.5 \mathrm{~cm}$ across. Sixtynine of the peridotites have sufficiently well-preserved primary textures to grade their crystal-plastic deformation, which averages C-P $0.7 \pm 0.7(1 \sigma)$. Only 1 mylonite was found, whereas there are 45 protogranular and 23 porphyroclastic peridotites. All the gabbros and gabbro veins are rodingitized by calc-silicate metasomatism indicating intrusion into serpentinizing mantle. Overall, the mantle section dredged is massive and argues for a sharp intrusive boundary between the crust and mantle to the east.

\section{Dives $10 \mathrm{~K} 174$ and 173}

Dives 6K 174 and 173 (Fig. 42) represent a broken transect up the eastern wall of the transform below the 


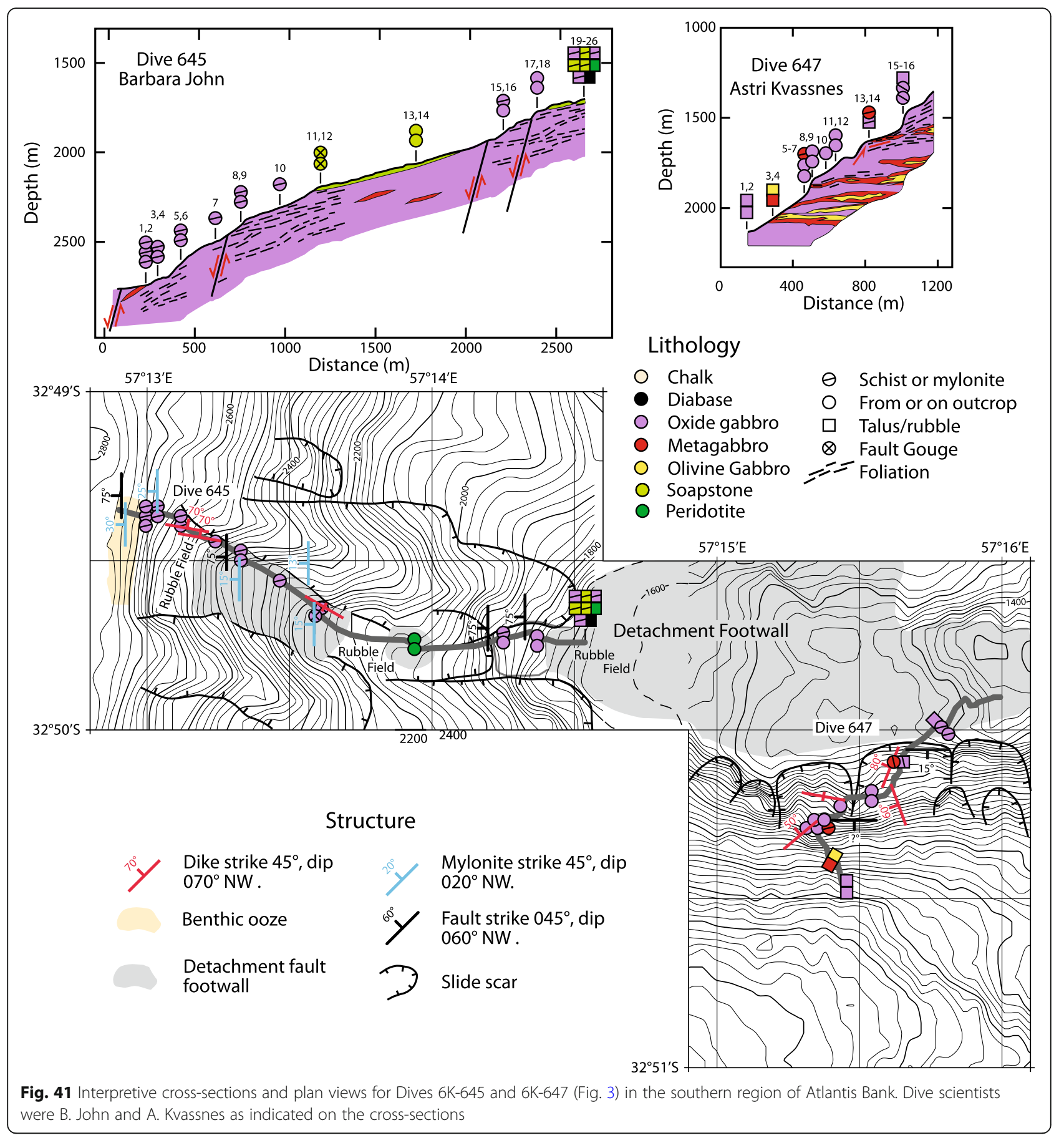

gabbro-peridotite contact. The dives sampled 2 generic peridotites, 4 plagioclase lherzolites, 37 lherzolites, 2 harzburgites, 3 olivine websterites, one metagabbro, and one diabase. With the exception of two mylonites sampled on the bench at $2958 \mathrm{~m}$ depth and one deeper at $3515 \mathrm{~m}$, the peridotites are only weakly to moderately deformed, with protogranular and porphyroclastic textures typical of large ophiolitic mantle massifs, averaging C-P grade $1.0 \pm 0.9(1 \sigma)$.
Overall, the mantle section is quite fertile in terms of a basaltic component, as indicated by the high Cpx contents of the peridotites, which means that unlike peridotites at the East Pacific Rise, or near hotspots, mantle melting did not reach $\mathrm{Cpx}$-out conditions, the point at which the MORB component of the mantle is exhausted. This means that the initial parental mantle composition was quite fertile, and despite the thick overlying crust at Atlantis Bank, 


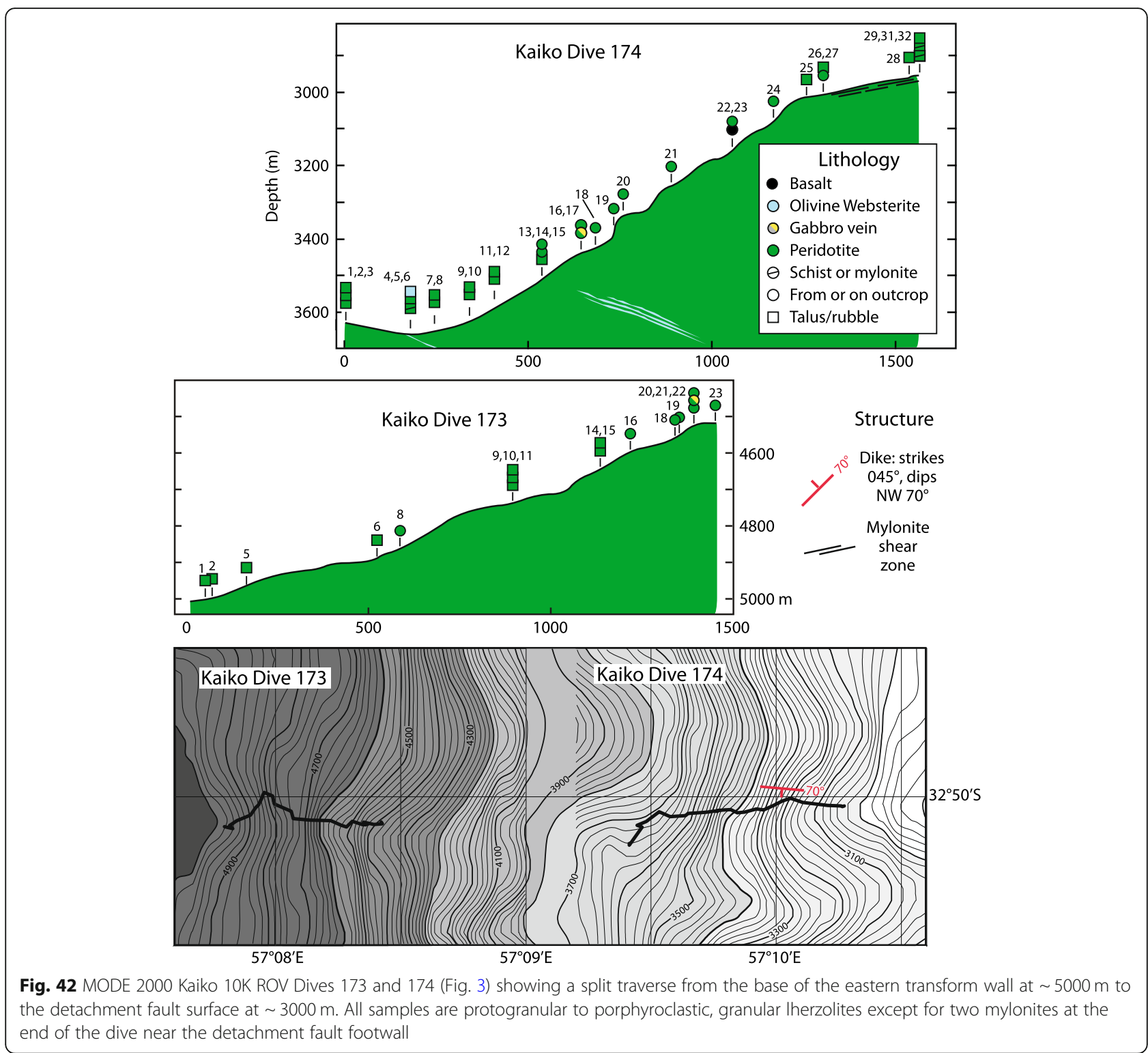

the available heat for melting was insufficient to exhaust it.

The plagioclase lherzolites contain $\leq 1 \%$ plagioclase pseudomorphs, indicating the presence of small amounts of trapped MORB-like melt at the end of melting. A single $1 \mathrm{~mm}$ wide gabbro vein was found cutting plagioclase lherzolite sample 10K-174-17, indicative of local segregation of a small amount of trapped melt in a crack at the end of mantle melting.

Sample $10 \mathrm{~K}-173-21$ has a $0.5 \mathrm{~mm}$ thick metagabbro (rodingite) bifurcating vein (Fig. 43a). Such veins are often precursors of an intrusive body, but in this case the intrusive body was small, or some distance away, because this is the only indication of intrusive gabbro in the entire $2800 \mathrm{~m}$ traversed by the two dives. Sample 10K-173-21 was collected on outcrop at $4511 \mathrm{~m}$, mid- depth up the mantle section in which the inferred gabbro-mantle contact is at $3000 \mathrm{~m}$ depth, $3 \mathrm{~km}$ to the east. Its presence so far below the inferred gabbromantle contact depth may be an indicator, however, that the gabbro-mantle contact in this region is not subhorizontal, but rather intrusive, even dipping to the west (e.g., Fig. 43b).

The last samples collected on Dive 10K-174 differ from the other peridotites collected on the traverse in that they are talcose, and include soapstone. Two of these show relict mylonite crystal-plastic fabrics, now largely pseudomorphed by talc and serpentine. Unlike most occurrences of talcose peridotites across Atlantis Bank, these do not appear to be directly associated with the gabbro massif, We suggest that here the detachment fault rooted directly into the mantle, and the talc schist 

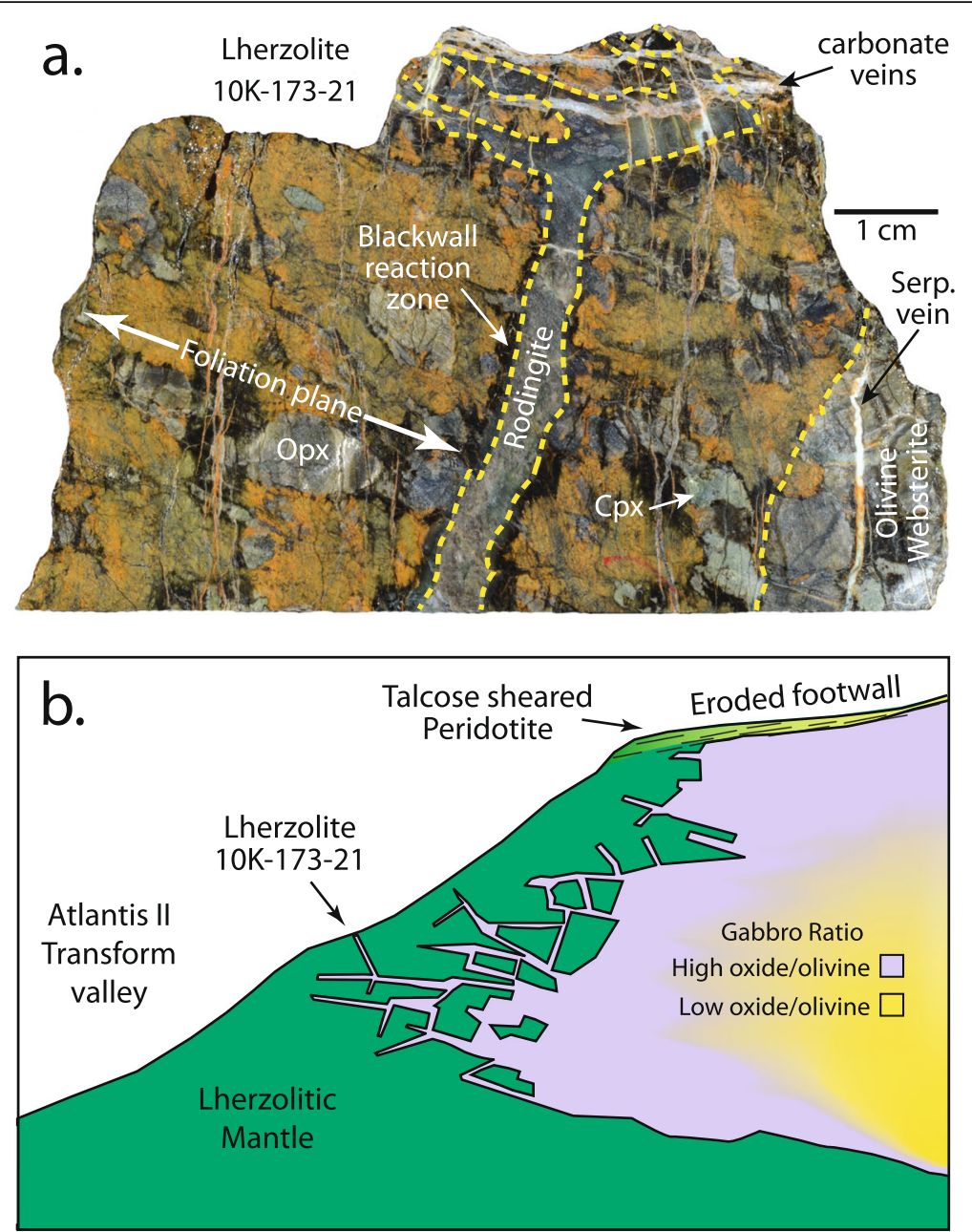

Fig. 43 a ROV Kaiko Dive 173 sample 21 (Fig. 42): Spinel Iherzolite and a crosscutting a metasomatized gabbro vein (rodingite) with a black-wall metasomatic reaction zone in the peridotite along the contact. The branching vein is part of a gabbro net vein complex in the peridotite, which is usually the indicator of a nearby intrusive body. On the right side is a selvage of olivine websterite consisting of enstatite, diopside, and olivine in sutured contact with the peridotite. $\mathbf{b}$ Cartoon showing possible configuration of the gabbro-mantle contact and, more speculatively, where it turns into the crust-mantle boundary beneath Atlantis Bank. The "Gabbro Ratio" reflects the transition from dominantly olivine gabbro intercalated with subordinate oxide gabbro to dominantly oxide gabbro intercalated with subordinate olivine gabbro as the mantle contact is approached

is the result of sea water-derived fluids percolating down the fault zone, resulting in formation of the talc schist, which then localized faulting to a narrow zone, limiting later serpentinization to static alteration.

\section{Dives 649 and 643}

Dives (Fig. 44) and 643 were located on the nose of another east-west-trending spur corresponding to a high-angle normal fault at $32^{\circ} 53^{\prime} \mathrm{S}$. This is the location of the gabbro-peridotite contact reported by Matsumoto et al. (2003), which they placed at $2562 \mathrm{~m}$ based on sampling and a photomosaic of the outcrop. However, the photomosaic images are of poor quality and the olivine gabbro sampled in outcrop at $2561 \mathrm{~m}$ immediately above where they place the contact is a large cobble in a carbonate-cemented breccia. In examining their photomosaic, we would interpret the proposed contact as a zone of carbonate-cemented talus, rather than outcrop, as affirmed by the breccia sample. Thus, what they identify as the crust-mantle boundary is actually talus piled on peridotite outcrop. The underlying peridotite section is riddled with carbonate veins, sufficient to call it ophicalcite, but the brecciation is clearly autoclastic, without significant clast rotation, so the outcrop lies in a zone of sub-vertical, low-temperature fluid upflow, which would be the source of the carbonate cement in the talus deposit.

In total, Dives 463 and 469 collected 16 lherzolites, one harzburgite, an olivine websterite, and a dunite between 3396 and $2561 \mathrm{~m}$. No evidence of talc was seen, and the peridotites are partially altered statically to serpentine. The majority are protogranular peridotites with 

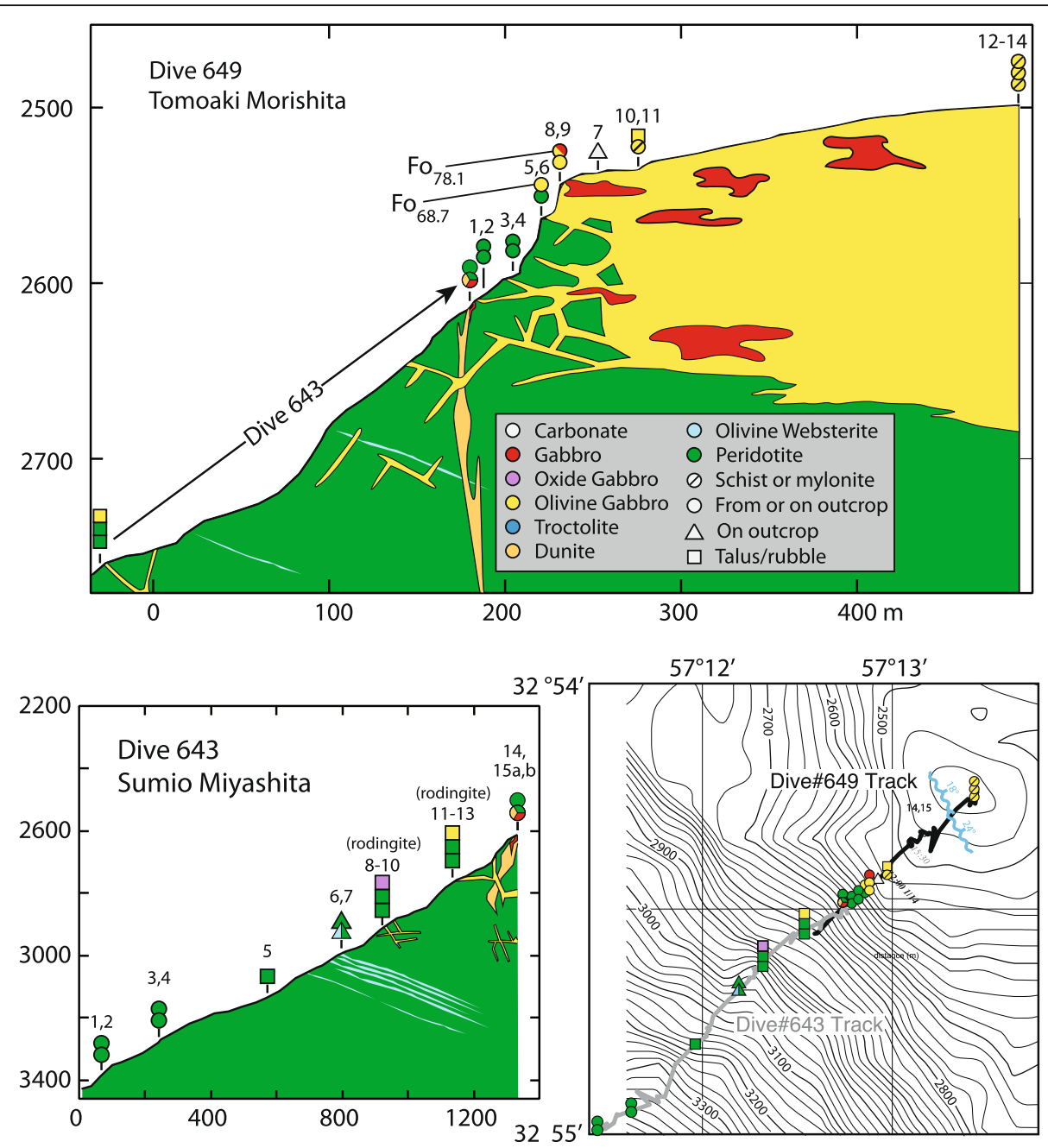

Fig. 44 Interpretive cross-sections and plan view for Shinkai 6500 Dives 643 and 649 (Fig. 3) across the gabbro-mantle contact. Dive scientists were T. Morishita and S. Miyashita as indicated on the cross-sections. Blue streaks represent olivine websterite layering

an average crystal-plastic deformation grade of $0.6 \pm 5$ $(1 \sigma)$. No systematic change in deformation grade was observed with depth.

The dunite contains several small sub-parallel stringers of chromite in an area otherwise consisting of massive peridotite and thus can be reasonably interpreted as representing a melt transport conduit in the mantle beneath the paleo-rift valley some $12 \mathrm{~km}$ from the transform fault boundary.

Dive 6K-649 sampled 8 olivine gabbros and a microgabbro between 2561 and $2493 \mathrm{~m}$ in a $67 \mathrm{~m}$ interval above the gabbro-peridotite contact. One ultramylonite was found at $2502 \mathrm{~m}, 60 \mathrm{~m}$ above the contact, well up in the crustal section. The remaining gabbros are variably undeformed to moderately deformed, with an average crystal-plastic deformation grade of $1.1 \pm 1.6(1 \sigma)$. The four samples collected above the contact at 2541 and
$2561 \mathrm{~m}$ are undeformed to very weakly deformed (C-P $0.1 \pm 0.3(1 \sigma)$.

The gabbros are all equigranular with no evidence of layering or mineral size grading with the exception of an irregular $8-\mathrm{cm}$ pegmatitic patch on the side of the microgabbro sample 6K-649-RO8a. Samples 649-R08 and R12 contain $\mathrm{An}_{50.4-58.7}$ plagioclase, $\mathrm{Mg \#}_{72.3-83.7}$ $\mathrm{Cpx}$, and $\mathrm{Fo}_{71.7-78.1}$ olivine (Fig. 44), corresponding to $\sim 66$ to $75 \%$ fractional crystallization of our model parent melt.

Thus, in the absence of talcose peridotites, and static serpentinization coupled with the undeformed character of the gabbro above the contact, the gabbro-peridotite contact here clearly represents lateral intrusion of an evolved basaltic melt considerably too fractionated to be even close to equilibrium with any MORB erupted in the region. 

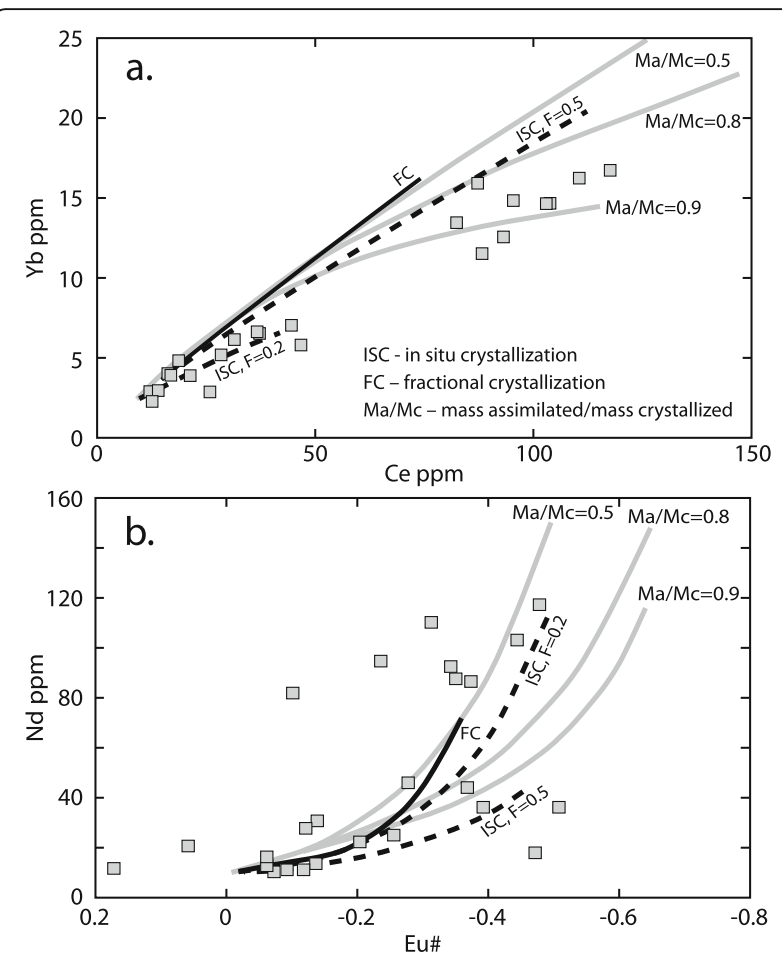

Fig. 45 Crystallization models for our samples compared to the hypothetical melts in equilibrium with the augites. a Plot of $\mathrm{Yb}$ vs Ce (ppm). It appears that the AFC-models and in situ fractionation fit the augite melts better than a pure fractional crystallization model. $M a$, mass assimilated; $M c$, mass crystallized; $f$, fraction of melt returned from the mush-zone to the magma chamber. $\mathbf{b}$ Plot of $\mathrm{Nd}$ $(\mathrm{ppm})$ vs Eu\#. Eu* $=\left(\mathrm{Eu}^{*}-\left(\left[\mathrm{Sm}^{*}+\mathrm{Gd}^{*}\right] \times 0.5\right)-1\right)$, where $\mathrm{Eu}^{*}, \mathrm{Sm}^{*}$, and $\mathrm{Gd}^{*}$ represent chondrite-normalized values. Negative Eu\# values represent negative Eu anomalies, indicating fractionation of plagioclase from the melt

\section{Dredge RC27-9-27}

Robert Conrad Cruise 27, Leg 9, Dredge 27 was made $\sim 1.5 \mathrm{~km}$ east of Dives $6 \mathrm{~K}-643$ and 649 on the flat bench at the western end of the $32^{\circ} 53^{\prime} \mathrm{S}$ fault at $2500 \mathrm{~m}$ depth. It recovered 2 diabases, 2 polymict diabase-gabbro breccias, 4 gabbro breccias, a polymict metagabbro breccia, 6 olivine gabbros, an oxide gabbro mylonite, and 8 samples of different limestones and chalk, including bioclastic and oolitic limestones (Fig. 23). No oxide gabbros, talcserpentine schists or peridotites were recovered. James Clark Ross Dredge $31 \sim 7 \mathrm{~km}$ farther east also recovered only two olivine gabbros just above a small eastern extension of this bench. The Conrad Dredge 27 assemblage and the seafloor morphology indicates that this is an erosional bench, which removed the primary, detachment fault damage zone, eroding down almost to the gabbro-peridotite contact. The oolitic limestones, chalk and bioclastic limestones demonstrate that this terrace was once within a few meters of sea level.

\section{Southern region summary}

Seafloor mapping shows that the gabbro massif in the southern area did not extend as far to the west as in other regions, reaching only to within $12 \mathrm{~km}$ of the transform plate boundary, indicating a lower magmatic budget. However, the gabbros from the gabbroperidotite contact are still highly evolved compared to those crystallized from a primitive melt. Thus, even here, the primitive olivine gabbros, dunites, and troctolites expected at the base of the crust and needed to mass balance the seafloor gabbros back to the composition of a likely parent MORB are missing. Overall, the gabbros from the southern region lie within the composition field for Hole 735B (Fig. 17d, $\mathrm{h}$ ), are quite evolved, and would not be in equilibrium with any MORB's sampled in the region, but representing 65-90\% crystallization of our model parental melt.

The mantle sections traversed by Dredge RC27-9, Kaiko Dives 173 and 174, and Shinkai Dive 643 are all massive protogranular to porphyroclastic peridotites, overwhelmingly Cpx-rich lherzolites, and thus the gabbro-mantle contact is sharp but locally laterally intrusive as shown in Figs. 43 and 44.

Once again, Shinkai Dives 645 and 647, which traversed over and across the eroded detachment footwall, found a thick uniform homogeneous zone of conformable oxide gabbro mylonite. Notable also is the occurrence of oolitic limestone sampled by Shinkai Dive 659 at $2647 \mathrm{~m}$ depth on the gently sloping footwall of the detachment fault, which again indicates deep subsidence of shallow-water shelf deposits.

\section{Regional variability of Atlantis Bank mineralogy}

There are differences in the seafloor gabbro mineral compositions from the different geographic areas of Atlantis Bank. In particular, in the northern region, where the gabbro massif is most deeply dissected by mass wasting on the transform wall, the mineralogy most closely resembles that of the upper $500 \mathrm{~m}$ of Hole 735B. The eastern section, on the other hand, lying closer to the midpoint of the paleo-ridge segment, lacks the extreme differentiates of the northern region and Hole 735B. The sample density for the western region is likely too small to capture the full variability there, whereas the southern region, located adjacent to the transform wall, and hence further from the midpoint of the paleo-ridge segment is more evolved. These variations likely reflect differences in geographic position with respect to where melts were initially intruded from the mantle into the massif, with those farthest from the segment midpoint being more evolved due to more fractionated melt reaching the distal end of the intrusion. 


\section{Discussion}

Mantle screens, and lack thereof, in the gabbro massif British Geologic Survey core BGS 12-1 drilled an autoclastic ophicalcite breccia with $\sim 50 \%$ pink to white, massive carbonate veins and $\sim 50 \%$ angular serpentinized peridotite clasts (Fig. 6) on an uneroded portion of the detachment fault surface on the southern flank of the wave-cut platform at $825 \mathrm{~m}$ depth. The clasts are statically serpentinized, granular peridotite, lacking talc, or tremolite. This lacks any evidence of melt infiltration, however, it could represent an isolated, undeformed, serpentinized peridotite enclave in the fault gouge. However, it could also represent a serpentinized peridotite screen within the gabbro massif similar to those found in the Atlantis Massif (Blackman et al. 2006), fortuitously exposed in the detachment fault footwall, and then brecciated with in situ growth of massive lithified carbonate due to the fluids from serpentinization (e.g., Schroeder et al. 2002).

Dredge 28 in the western region sampled an extensive suite of peridotite mylonites just below the beginning of Shinkai Dive 6K-459, representing an apparent inlier of peridotite intruded by the gabbro in the transform zone before uplift. There is no evidence of melt infiltration in these samples, however, and the dive sampled peridotite mylonites immediately above the dredge track. Moreover, several of the mylonites have a thick talc rind lying parallel to the foliation plane, indicating silica metasomatism along a fault plane from a nearby gabbro body, followed by static serpentinization of the mylonite (Fig. 34). This indicates that the beginning of Dive 459 represents the point at which the detachment fault passed out of the westward-intruding, massive gabbro into massive peridotite in the transform.

Dredge 36 recovered 2 protogranular metaperidotites, 12 metagabbros, 2 rodingites, 9 oxide gabbros, and 4 olivine gabbros on the middle of the transform wall at $3200 \mathrm{~m}$. One of the peridotites is soapstone, implying a large transfer of silica into it, whereas rodingites are common where the mafic rocks are in proximity to serpentinized ultramafic rocks (Bach and Klein 2009). Dredges 33 and 37, and Dive 459, immediately above them, all sampled gabbro and gabbro mylonites between 1850 to $2950 \mathrm{~m}$ (Fig. 3) and Dives 466 and 458 sampled gabbro on the wall below it. The pseudomorphed protogranular textures, rather than peridotite mylonite, and the rodingites all indicate that the peridotites represent a local inlier of mantle peridotite in massive gabbro, well below the detachment footwall, consistent with gabbro outcrops sampled above and below it. Notably, Dredge 28 and Dive $4593 \mathrm{~km}$ to the south where the detachment fault passes from the gabbro massif into the mantle, show that this inlier must lie close to the major intrusive gabbro-peridotite contact. Thus, it is likely an isolated screen of mantle peridotite where it was laterally intruded by the gabbro at the ridge-transform intersection prior to uplift onto the transform wall. It is far less likely that it represents a rafted mantle block within a gabbro massif as found in Hole 1309D at Atlantis Massif. With these exceptions, there is no evidence for peridotite screens within the Atlantis Bank Gabbro Massif.

\section{Geochemistry}

On the basis of trace element partitioning, the liquids in equilibrium with the seafloor gabbros would be slightly LREE enriched, which is unexpected given the distance from any mantle hotspot, particularly as the heavy isotopes are those of a highly depleted MORB (Robinson et al. 2001; Snow 1993). Robinson et al. (2001) showed that the rift mountain basalts north of the SWIR, contemporaneous with the Atlantis Bank gabbros, likely formed by fractional melting of a mantle with a potential temperature similar that of the Mid-Atlantic Ridge at $23^{\circ} \mathrm{N}$, where typical flat REE patterns are found. They ascribe the difference in trace element compositions and melt production to the presence of a $20 \mathrm{~km}$ thick conductive lid on the mantle due to ultraslow spreading resulting in a larger fraction of melting in the garnet stability field. This then accounts for the melt REE patterns inferred from the Atlantis Bank seafloor gabbros.

Robinson et al. (2001) also calculated a $3 \pm 1 \mathrm{~km}$ crustal thickness by inverting their trace element data, which is much thinner than found by Muller et al. (1997), assuming that the seismic Moho represents the crustmantle boundary. This is consistent, however, with the gabbro-peridotite contact mapped on the transform wall, if it were the crust-mantle boundary contact, but is thinner than what is estimated based on fluid inclusions (Vanko and Stakes 1991), and our geologic mapping. Robinson et al. (2001) and White et al. (1992), however, assume a uniform upper mantle composition beneath the SWIR, which is demonstrably incorrect (Zhou and Dick 2013; Dick and Zhou 2015). However, it is clear that the contact along the transform wall is intrusive, and not the MOHO, or even a depositional contact of gabbro overlying serpentinized mantle. Determining an appropriate mantle source composition might reconcile these different approaches.

The Atlantis Bank seafloor gabbro suite is the product of very dynamic accretion such as that in the ODP drill cores from Atlantis Bank (Cannat 1991; Cannat et al. 1991; Dick et al. 1991a; Dick et al. 2000; Robinson et al. 1991) and IODP cores (Dick et al. 2017; MacLeod et al. 2017a) which document episodic intrusion but continuous extension due to far-field plate-tectonic forces. Moreover, there is abundant evidence in the oxide 


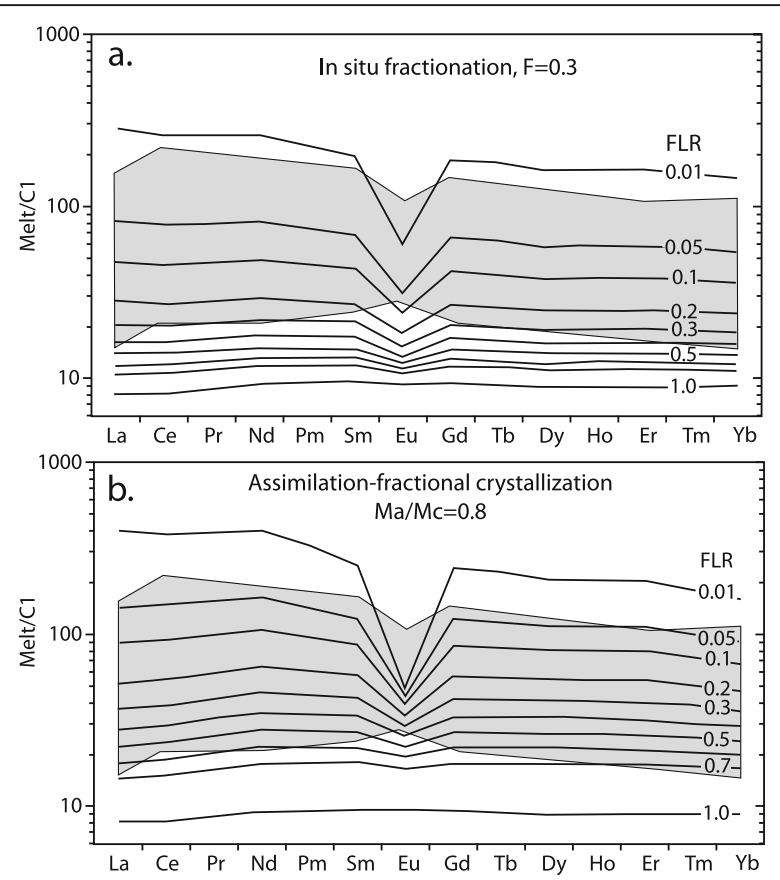

Fig. 46 C 1 chondrite-normalized REE plots for crystallization models (Taylor 1985). FLR equals the fraction of liquid remaining, and the black lines describe the degree of fractionation. The gray field outlines the theoretical melt compositions based on the gabbro augite compositions. a In situ fractionation model, where only 30\% of the interstitial melt is returned from the mush-zone to the central magma. $\mathbf{b}$ Assimilation-fractionation model, where crystallization of the DMM-derived melt takes place during bulk assimilation of the average olivine gabbro from Hole 735B (Natland and Dick 2001). The diagram demonstrates that even if the melt assimilated pre-existing olivine gabbro, the gabbros represent melts that first fractionated $50 \%$ elsewhere, but then crystallized to near completion

gabbros for large-scale permeable flow and melt-rock reaction that played a major role in the stratigraphic and chemical evolution of the lower crust.

Simplistic models such as fractional and in situ crystallization are simply inadequate to explain the geochemical variability of the seafloor gabbro suite. The REE compositions of the gabbros are shown in Fig. 45 with the liquid lines of descent for magmas calculated for: (1) fractional crystallization (i.e., Rayleigh fractionation); (2) in situ crystallization (Langmuir 1989), where magmas crystallize to form a mush along the walls of a magma chamber with varying fractions of the interstitial melt (F) recirculating to the main magma body; and (3) assimilation-fractionation-crystallization (AFC; DePaolo 1981) involving a typical Atlantis Bank olivine gabbro. The liquid lines of descent represent 0-90\% crystallization relative to a primitive MORB calculated from DMM. The bulk-partition coefficients are calculated assuming fractionation of 35\% augite, $15 \%$ olivine and $50 \%$ plagioclase for all stages of crystallization. This modeling shows that in situ crystallization, where a small fraction of the interstitial melt is returned to the magma body, or AFC, where the mass assimilated is similar to the mass crystallized, describe the evolution of the augites better than simple fractional crystallization (Fig. 45b). However, it also shows that none of these models work very well and that the gabbros must have had complex, multi-stage evolutions that cannot be simply modeled. The best fitting AFC and in situ-model are further investigated in Fig. 46. While the fit of the data to the models in Figure 46 is unimpressive, if either either AFC or in situ fractionation did control the melt evolution, then the range of gabbro trace element concentrations would represent $>50-95 \%$ crystallization of the primary MORB, consistent with major element modeling (e.g., Fig. 19).

\section{Melt-rock reaction and the depth of crystallization}

The depth of origin of abyssal gabbros has long been contentious, with a major school of thought favoring high-pressure (e.g., 10-30 kb) crystallization followed by emplacement by crystal-plastic deformation into the crust (e.g.: Elthon et al. 1982). This is argued based on the strong correlated decreases of $\mathrm{CaO}-\mathrm{MgO}$ in $\mathrm{MORB}$ glass suites, which require early crystallization of highmagnesian augite. Yet experimental petrology shows that at low-pressure clinopyroxene appears after olivine + plagioclase (Grove et al. 1992a; O’Hara 1968; Presnall et al. 1978). This, and high-magnesian augite in abyssal gabbros, is taken as requiring a high-pressure origin. Petrographic data, however, argue strongly against a high-pressure origin (Lissenberg and Dick 2008; Meyer et al. 1989). Specifically, high-magnesian augite commonly occurs as undeformed oikocrysts enclosing plagioclase chadocrysts, and thus reflects a low-pressure crystallization sequence (e.g., Fig. 13). High-magnesian augite oikocrysts (Mg\# 86.0-90.7) also coexist with low anorthite plagioclase $\left(\mathrm{An}_{83-65.6}\right)$, which also implies late crystallization (Lissenberg and Dick 2008).

This paradox, however, likely reflects a failure to account for the chemical effects of post-cumulus crystallization in abyssal gabbros (Lissenberg and Dick 2008; Meyer et al. 1989). Barnes (1986), for example, has shown that crystallization of $30 \%$ trapped liquid can shift the mineral Mg\#' by up to $10 \%$. In the case of Atlantis Bank, the effect of infiltration of late iron-titanium-rich melts on the olivine gabbros is easily seen. Less obvious are the cryptic effects of post-cumulus, interstitial crystallization of only moderately fractionated melt, which can raise both the $\mathrm{Mg \#}$ and $\mathrm{TiO}_{2}$ contents of augite, and lower the anorthite content of the coexisting plagioclase (Lissenberg and Dick 2008; Meyer et al. 1989). Meyer et al. (1989), for example, show that the crystallized products of intercumulus trapped melt can comprise 3-15\% 

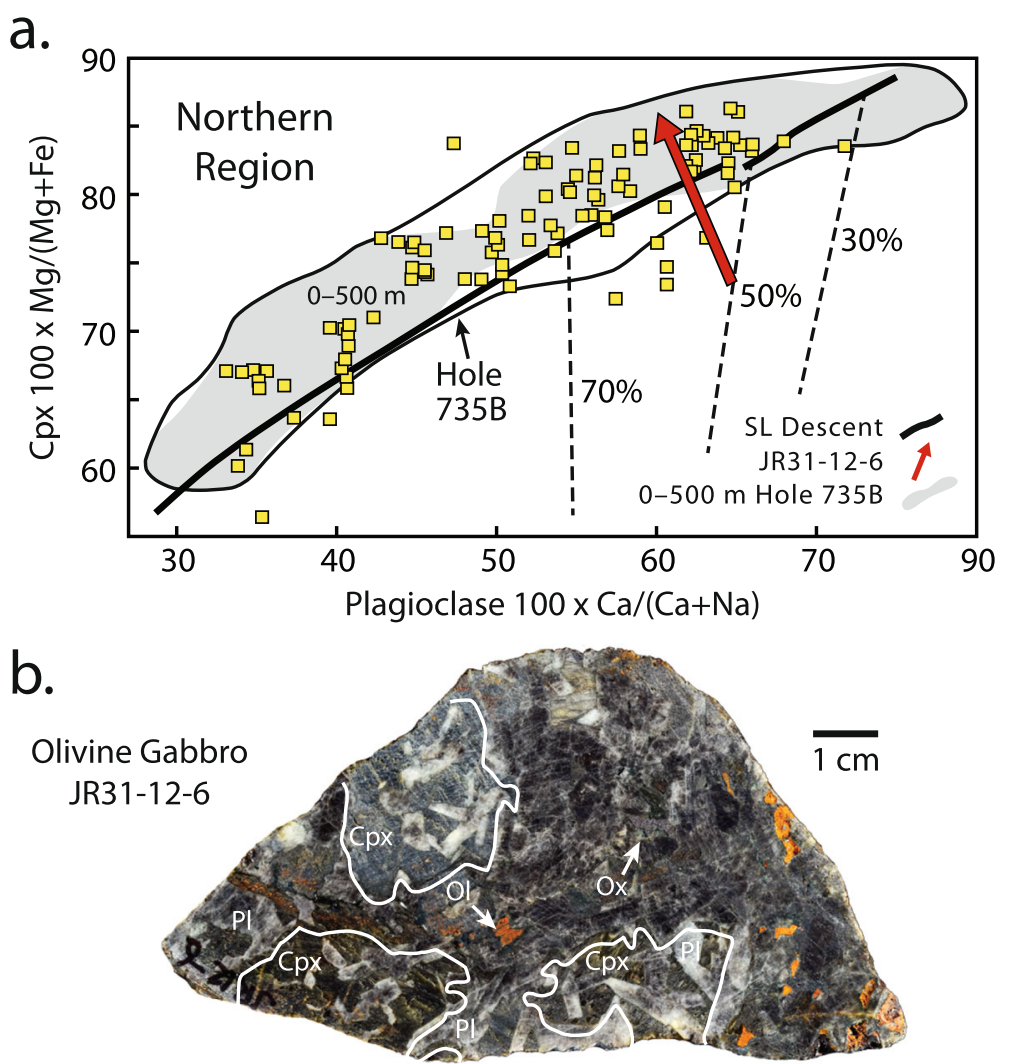

Fig. 47 a Plot of Mg\# in augite vs plagioclase anorthite content for the northern seafloor gabbros: red arrow shows the inferred trend between the most calcic and least magnesian and the least calcic and most magnesian plagioclase and augite in oikocrysts in olivine gabbro of JR31-12-6. Solid black line is the line of descent (SLD) for fractional crystallization calculated for a parental melt. The dashed lines, extending from the SLD towards the coexisting melt composition, are labeled with the percent crystallization. Gray-shaded field shows the composition range for the upper 500 m of Hole 735B. b Sample JR31-12-6 showing three euhedral to anhedral, augite oikocrysts (lower left), and plagioclase chadocrysts in pegmatoidal olivine gabbro with 8-10\% intergranular olivine

of the abyssal gabbros on SWIR at $7^{\circ} 16^{\prime}$ E. Although this effect raises the Mg\# of augite in an olivine gabbro, due to augite replacing olivine by reaction, it can also lower the Mg\# where olivine is not involved in the reaction, as in an ordinary gabbro, where the effect depends on the modal abundance of olivine in the initial cumulate (e.g., Kvassnes and Grove 2008). Because early cumulates are olivine rich, the result is the production of abundant high-magnesian augite in such rocks with relatively low anorthite content.

Although major element modeling shows that fractional crystallization can explain the first-order chemical variability of coexisting pyroxene and plagioclase in the seafloor gabbro suite, it poorly explains their large variation in $\mathrm{Mg \#}$ at a given plagioclase composition. This could be the product of variable primary melt compositions reflecting large variations in mantle potential temperature or mantle source composition. The former seems unlikely, however, due to the short time scales involved, whereas the latter may explain systematic shifts in the data such as is seen for the trends for Hole 735B and 1105A (Fig. 17d). However, a shift in over 10\% Mg\# at constant anorthite in closely spaced samples or within a single dredge due to mantle potential temperature or source variations seems very unlikely.

MELTs modeling also produces a misfit between the calculated position of the solid line of descent for our parental magma and the actual gabbro mineral compositions. Nearly all the latter have higher than predicted $\mathrm{Cpx} \mathrm{Mg \#} \mathrm{at} \mathrm{a} \mathrm{given} \mathrm{anorthite} \mathrm{content} \mathrm{(e.g.,} \mathrm{Fig.} \mathrm{47a).}$ This could be because MELTS is based on limited thermodynamic data, leading to a systematic shift in the predicted mineral compositions from the actual result. This again, however, does not explain the vertical spread of the data.

Thus, another explanation is required, and postcumulus crystallization of intercumulus or transient melt seems evident based on the preceding discussion. Large-scale permeable melt flow in the Atlantis Bank gabbros is demonstrated by the well-documented hybridization of olivine gabbro to oxide gabbro by transient Fe-Ti-rich melts. Less obvious, however, are 
the cryptic variations due to post-cumulus interstitial crystallization of primitive or moderately evolved melts as they are recorded only in the silicate chemistry. Lissenberg and Dick (2008) identified two augite types in the Kane Megamullion troctolites and troctolitic gabbros: Type I intergranular augite and Type II augite oikocrysts. Crystallization of intercumulus and transient melts likely explain these textures, with an increase in $\mathrm{Cpx} \mathrm{Mg \#}$ and decrease in plagioclase anorthite being produced as a result of the exchange reaction:

$$
\begin{aligned}
& (\mathrm{Mg}, \mathrm{Fe})_{2} \mathrm{Si}_{2} \mathrm{O}_{4}+\mathrm{CaAl}_{2} \mathrm{Si}_{2} \mathrm{O}_{8}+L_{1} \\
& \quad=\mathrm{Ca}(\mathrm{Mg}, \mathrm{Fe}) \mathrm{Si}_{2} \mathrm{O}_{3}+\mathrm{NaAlSi}_{3} \mathrm{O}_{8}+L_{2}
\end{aligned}
$$

where $L_{1}$ is the intercumulus or transient liquid, and $L_{2}$ is liquid enriched in $\mathrm{MgO}$ and $\mathrm{Al}_{2} \mathrm{O}_{3}$, and depleted in $\mathrm{SiO}_{2}$ (as well as $\mathrm{CaO}$ depending on the mineral proportions involved in the reaction). Noting that the Mg\# of olivine due to mineral-melt partitioning is much higher than that of the liquid, the increase in $\mathrm{Cpx} \mathrm{Mg \#} \mathrm{occurs}$ as olivine, with $2 \mathrm{Mg}$-Fe cations is replaced by augite with $1 \mathrm{Mg}$-Fe cation, increasing the $\mathrm{Mg \#}$ of both the liquid, and the coexisting equilibrated augite.

Where this reaction does not go to full equilibration the effect can be seen in compositional variations at thin section scale, as in Sample JR31-12-6 (Fig. 13). This sample is composed of intergranular olivine and coarse plagioclase and large augite oikocrysts that exclude olivine and enclose sub-equant to resorbed plagioclase chadocrysts (Figs. 13, 47b). The latter are very similar to the Type II augite oikocrysts of Lissenberg and Dick (2008) and as shown by the red arrow in Fig. 47, Cpx Mg\# and coexisting plagioclase anorthite vary from 73.6 to 86.1 and $\mathrm{An}_{60.2}$ to $\mathrm{An}_{64.7}$ respectively within a single thin section.

Thus, we conclude that there is very little evidence for high-pressure crystallization of the Atlantis Bank gabbros. Rather, the strong interrelationships between the roots of the detachment fault and late-stage flow of interstitial melt, as well as the large volume of complex, undeformed magmatic textures in the gabbros support a shallow depth of crystallization above the gabbroperidotite contact.

\section{Oxide mylonite cap}

We find there was a near-continuous layer of oxide gabbro mylonite up to a hundred meters or more thick that appears to have extended over the entire massif. It is conformable to the detachment fault surface and to a zone of intervening cataclastic gabbros and diabase and overlying talc-serpentine schists, which constitute the detachment fault damage zone. Discontinuities in this zone appear to be largely due to erosion and mass wasting. From the uppermost cores recovered in the ODP and IODP holes on down, the magmatic, gneissic, and mylonitic crystal-plastic foliations are nonconformable to the detachment surface, ranging from rare $0^{\circ}$ to rare nearly vertical dips, and averaging around $35^{\circ}$ (e.g., Casey and Miller 1999; Casey and Miller 2007; Dick et al. 2017; Dick et al. 1991a; MacLeod et al. 2017b; Natland et al. 2002). Thus, neither the uppermost conformable oxide gabbro mylonite layer nor the cataclasites and serpentinite were drilled on the platform, despite being abundant in the seafloor sample suite.

The oxide gabbro mylonites show that late $\mathrm{Fe}$-Ti-rich liquids migrated into the detachment fault shear zone deep beneath the rift valley floor throughout formation of the gabbro massif, placing a key restraint on the fault geometry. Deformation in the mylonites, however, clearly continued in the sub-solidus region, and hence mask the earlier textures produced by hybridization of the original gabbro cumulates by the infiltrating melts. Examples of shear localization of such melts are abundant in many of the Atlantis Bank seafloor samples and in the IODP and ODP drill holes (e.g., Dick et al. 1991a; Dick et al. 2000; MacLeod et al. 2017b; Natland and Dick 2001; Natland and Dick 2002; Natland et al. 2002).

Based on the abundance of oxide minerals, which are present in only trace amounts in the upper $100 \mathrm{~m}$ of Hole 735B core, and first become really abundant below $220 \mathrm{~m}$ (Robinson et al. 1989), our traverses near the crest of the bank (e.g., Fig. 38) likely did not go deep enough below the fault damage zone to reach that section. Thus, without drilling the fault damage zone where it is intact, we cannot provide an accurate assessment of the thickness of this zone, and what was removed by erosion at Site 735 , though it is likely not much more than $100 \mathrm{~m}$ or so.

\section{Serpentinite veneer}

Serpentinite, talc, and tremolite in various combinations, commonly with enclaves of less deformed and less altered peridotite and peridotite mylonite, are the first sign of an uneroded section of the primary detachment footwall at Atlantis Bank, appearing wherever the fault surface has not been degraded by erosion and mass wasting. These assemblages reflect varying conditions of alteration and fluid composition, reflecting in part the time transgressive nature of an evolving fault plane from the ductile through the brittle deformation field. Serpentine forms by replacement of olivine and pyroxene at temperatures below about $500-600^{\circ} \mathrm{C}$ in the presence of water (Bowen and Tuttle 1949; Evans et al. 1976). There are three different hydration reactions involved, one at lower temperature that produces serpentine plus brucite and hydrogen, a second that produces serpentine plus magnetite plus hydrogen at higher temperatures, and a 
third where olivine and orthopyroxene react with water to produce serpentine plus hydrogen (e.g., Schroeder et al. 2002). However, the common serpentines in abyssal peridotites, lizardite, and chrysotile, likely have an upper temperature limit of $350-400{ }^{\circ} \mathrm{C}$ (e.g., McCollom et al. 2016; O'Hanley 1996). Escartin et al. (1997a, 1997b) found that serpentine reduces the strength of the lithosphere by as much as $30 \%$, and thus has a profound effect on crustal rheology. Talc is stable up to $800^{\circ} \mathrm{C}$, much higher than serpentine (Bowen and Tuttle 1949), and has very low shear strength, $~ 36 \%$ that of antigorite at comparable P and T (e.g., Moore and Rymer 2007). It forms by the following reactions:

$$
\mathrm{MgSiO}_{3}+\mathrm{SiO}_{2}+\mathrm{H}_{2} \mathrm{O}=\mathrm{Mg}_{3} \mathrm{Si}_{4} \mathrm{O}_{10}(\mathrm{OH})_{2}
$$

and

$$
\begin{aligned}
& 3 \mathrm{Mg}_{2} \mathrm{SiO}_{4}+2 \mathrm{H}_{2} \mathrm{O}+5 \mathrm{SiO}_{2} \\
& =2 \mathrm{Mg}_{3} \mathrm{Si}_{4} \mathrm{O}_{10}(\mathrm{OH})_{2}
\end{aligned}
$$

Although reaction (1) can begin in the granulite facies, olivine is stable in the presence of water down to $400{ }^{\circ} \mathrm{C}$, so reaction (2) begins within the greenschist facies. Talc also forms by breakdown of serpentine with the introduction of a siliceous fluid by the following reaction:

$$
\begin{aligned}
& \mathrm{Mg}_{3} \mathrm{Si}_{2} \mathrm{O}_{5}(\mathrm{OH})_{4}+2 \mathrm{SiO}_{2} \\
& \quad=\mathrm{Mg}_{3} \mathrm{Si}_{4} \mathrm{O}_{10}(\mathrm{OH})_{2}+\mathrm{H}_{2} \mathrm{O}
\end{aligned}
$$

Thus, hydrothermal alteration of abyssal peridotite often begins with formation of talc rims on enstatite below $800^{\circ} \mathrm{C}$. However, more extensive alteration at lower temperatures requires a siliceous fluid for talc to form from olivine and serpentine. Such fluids are produced by hydrothermal alteration of gabbro. Where such fluids are unavailable, as where a detachment fault roots deeper in the mantle, deformation and recrystallization by dislocation and diffusion creep can produce ultramafic mylonites down to $600{ }^{\circ} \mathrm{C}$ (Jaroslow et al. 1996). Pseudomorphed enclaves of such mylonites are found in the talc-serpentine fault gouge at Atlantis Bank, and thus were likely entrained within serpentinized and talcose peridotite that later intruded along the active fault.

The talc and talc-serpentine schists found along the detachment footwall, then, reflect alteration of pyroxene, olivine, and serpentine in the presence of siliceous fluids circulating into the fault zone from the gabbro massif. With olivine stable in the presence of talc down to $400{ }^{\circ} \mathrm{C}$, the soapstones found in the shear zone would reflect intermediate temperatures of alteration, consistent with greenschist facies diabase and gabbro cataclasites, both of which are also found in the fault damage zone. Where siliceous fluids below $\sim 800^{\circ} \mathrm{C}$, produced by hydrothermal alteration in the lower crust, migrated into a shear zone in the mantle section near the transform, this crystal-plastic deformation would immediately terminate due to the formation of talc that would then intrude up the now brittle fault as has been observed at the Kane Megamullion (Dick et al. 2008).

Serpentinite, soapstone, and talc-serpentine schist were sampled at 19 locations on the detachment footwall of Atlantis Bank. Unlike Hole 1309D located on the Atlantis Massif of the Mid-Atlantic Ridge, peridotite was not sampled in any of the Atlantis Bank ODP and IODP drill holes. Nor was it cored by the BGS and BRIDGE drills on the wave-cut platform, due to erosion, as indicated by serpentinite pebbles found in the carbonate-cemented beach conglomerates of Dredge 34 (Fig. 5). Such metaperidotites, however, were repeatedly sampled on long transects over uneroded, smooth, lightly sedimented slopes interpreted as the detachment fault footwall (e.g., Shinkai Dive 6k-460), and along ridges where the footwall was preserved between landslip scars. The largest outcrop area of the talc-serpentine schists extends from $32^{\circ} 42^{\prime}$ to $32^{\circ} 47^{\prime}$ $\mathrm{S}$ west of Hole 735B (Fig. 3). Where observed in situ (e.g., Kaiko Dive 10K-172), the serpentinites and talc-serpentine schists are thin (meter scale), deformed, schistose, and conformable to the detachment fault surface. They frequently contain phacoids or shear polyhedra of less deformed partially serpentinized peridotite or more massive talc and serpentine. The talc-serpentine schists then represent what was once a nearly continuous serpentinite veneer on the detachment footwall prior to erosion and mass wasting. It was thus intruded laterally along the detachment fault from where it rooted in mantle peridotite near the transform. Enclaves of pseudomorphed peridotite mylonite in the serpentinites attest to an earlier high-temperature, localized, anhydrous crystal-plastic deformation, where the detachment rooted in the mantle peridotite rather than in gabbro. When the detachment fault was exposed on the seafloor, this talc-serpentine schist formed a veneer over the footwall.

The presence of extensive greenschist facies alteration and contemporaneous cataclasis in many of the mafic mylonites shows that the talc-serpentine schists must have intruded the detachment fault well up in the brittle deformation zone above the brittle-ductile transition. This is most evident from the Kaiko Dive 10K-172 transect where oxide gabbro mylonites were found as clasts within the cataclasites beneath the talc-serpentine schist (e.g., Fig. 36c), indicating that the talc-serpentine schists were intruded well after brittle deformation started in the gabbros and dikes.

\section{Detachment fault stability and orientation}

The discovery of the exposure of lower crust and shallow mantle directly on the seafloor by long-lived detachment faulting at slow-spreading ridges (Dick et al. 1981) was first viewed as an anomaly. It is now known, 
however, to be a general phenomenon, representing a major form of seafloor spreading at slow- and ultraslowspreading ridges (Escartin et al. 2008; Smith et al. 2008). At first, this was thought to simply expose the underlying basement as formed in the case of symmetric spreading where crust is rifted apart at the ridge axis with an intact section of lavas, dikes, and gabbro spreading in each direction. However, detachment faulting does not simply remove the pillow lavas and dikes, but also involves significant modification of the lower crust in the resulting core complex. The crust and lithosphere below the fault plane at Atlantis Bank are substantially modified due to melt migrating into fault zones, slab bending and rollover, and the consequent internal stresses creating zones of extension and compression, and a steepened geotherm. The internal stratigraphy of Atlantis Bank shows this resulted in extensive crystal-plastic deformation and focusing of late iron-titanium-rich melt into shear zones, significantly modifying the igneous stratigraphy, as well as producing late moderate-temperature amphibolite facies hydrothermal alteration in the upper kilometer of the gabbro massif.

The maintenance of a low-angle fault over the millions of years it took to expose the Atlantis Bank Core Complex is theoretically improbable according to Anderson (1905) due to the effect of normal stress provided by the lithostatic load on the fault plane. However, low-angle detachment faults are abundant at slow and ultraslowspreading ridges. Where they intersect the seafloor, detachment faults typically slope at low angles, often as little as $14^{\circ}$ (e.g., Smith et al. 2014). Initially, these start as high-angle normal faults at $\sim 30^{\circ}$ to vertical where the optimal balance between the resolved normal and shear stresses occur. With continued tectonic extension across the rift valley, the fault plane rotates, leading to a steady increase of the effective normal stress on the fault plane due to the lithostatic load while resolved shear stress decreases. The fault remains active because the frictional sliding strength is less than that for shear failure of intact gabbro. With continued rotation, however, as the effective normal stress on the fault plane increases, the sliding strength increases until the fault strength exceeds that for shear failure of the intact gabbro, causing it to finally lock (e.g., Poliakov and Buck 1998).

Once the fault locks, a new one forms, generally, but not always, with an inward jump towards the rift axis. In the Atlantis Bank case, after the primary detachment fault locked, a high-angle normal fault propagated from the eastern rift valley wall through the northern end of the massif, initiating a new relatively short-lived detachment fault that split the gabbro massif, down-dropping its northern end, which was subsequently covered by young rift valley lavas. This also realigned the axis of spreading with that in the rift valley to the east. A similar ridge jump has also been documented at the $5^{\circ} \mathrm{S}$ Fracture Zone by Reston et al. (2002), which split a plutonic massif at the eastern inside-corner high, whose opposing blocks are now separated by a broad rift valley.

Long-lived detachment faults form where there is sufficient lubrication of the fault plane to reduce its cohesive strength sufficient for it to remain active to very-low angles, resulting in asymmetric spreading and the exposure of deep plutonic rocks from beneath the lavas and dikes of the upper crust. In the case of Atlantis Bank, the lithosphere is substantially thinner than usual for detachment faulting due to the associated robust magmatism. Fabric studies indicate that strain localization at Atlantis Bank occurred initially in the hyper-solidus region, with dynamic recrystallization of plagioclase from 910 to $650^{\circ} \mathrm{C}$, then by amphibole-accommodated, dissolutionprecipitation creep between $\sim 750$ and $450{ }^{\circ} \mathrm{C}$, followed by chlorite-accommodated reaction softening from $\sim 450$ to $300{ }^{\circ} \mathrm{C}$, and finally fracturing and cataclasis at temperatures $<300^{\circ} \mathrm{C}$ (Miranda and John 2010). Initially, the detachment fault rooted into and terminated in partially molten gabbro at a relatively high level (Dick et al. 1991a; Dick et al. 2000). As a result, due to the higher permeability in the active shear zone, melt flowed into and along the active fault from the enclosing matrix, which lubricated it and enhanced ductile deformation by magmatic dissolution and re-precipitation. The melt relieved normal stress on the fault plane, while also substantially decreasing the shear strength of the gabbro. Infiltration of late Fe-Ti-rich melts into the shear zone would also concentrate volatiles there, which would further enhance fault lubrication as these worked their way up the fault zone into the sub-solidus region with additional fluids drawn in from the host gabbro (Kelley and Früh-Green 2001). At the same time, serpentine intrusion higher in the fault plane in the brittle zone also lubricated it due to its low shear strength, while talc-serpentine schist, or soapstone, was even more effective in stabilizing the fault zone. These factors, in combination, greatly reduced the shear strength in the plane of sliding both above and below the brittleductile transition, allowing the fault to operate for a long period of time.

Significant debate exists as to the geometry in the down-dip direction of detachment faults below their termination on the seafloor. A rolling hinge down-dip model is generally favored, where the fault plane plunges towards vertical into the lower crust and mantle, which in part resolves the mechanical problem presented by the fault mechanics discussed by Anderson (1906). It seems clear though that the detachment fault at Atlantis Bank initially consisted of a relatively broad shear zone that rooted into partially molten oxide gabbro at relative shallow depth. Thus, the fault likely terminated at a relatively shallow dip rather than plunging down into the upwelling lithosphere. Melt migrating into the shear 


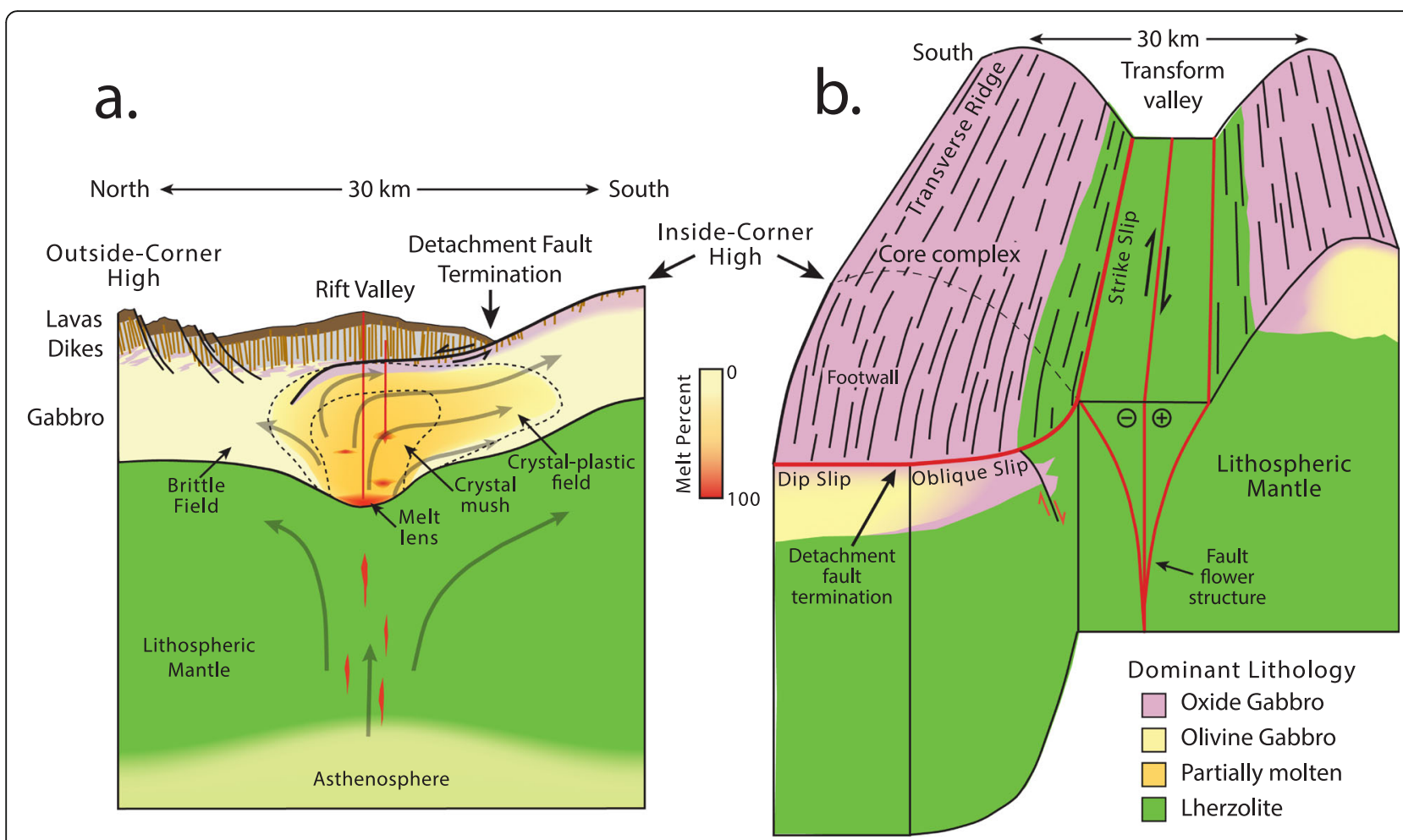

Fig. 48 Orthogonal cartoons of a tectonic model for Atlantis Bank emplacement: a N-S cross-section of the paleo-rift valley and opposing outside and inside-corner highs $\sim 15 \mathrm{~km}$ east of the ridge-transform intersection. The gabbro above the melt lens migrates diapirically as a mush, by crystal-plastic flow at low melt \%, and then by solid-state crystal-plastic deformation. Small higher level intrusions locally crosscut the fabric of the rising gabbro diapir as an ongoing process. Heavy red line shows the detachment fault cutting through the dike-gabbro transition into partially molten gabbro. It extends beneath the rift valley, resulting in fault capture and asymmetric spreading of the lower crust to the south parallel to the transform. Late, interstitial melt moved upward (and laterally) to create an oxide gabbro rich zone in the upper $500 \mathrm{~m}$ of the lower crust and migrated into the detachment fault zone to form an oxide gabbro rich mylonite that extends over the core complex. Gray arrows show lithospheric flow which extends up to the dike-gabbro transition. Fields for brittle, crystal-plastic, and crystal mush deformation and flow are separated by the thin dashed lines. Note that the crystal-plastic field overlaps the partially molten region at low melt percent. b Threedimensional cartoon looking from north to south at right angles to the cross-section in "A". Late E-W brittle faulting during lithospheric rollover and mass wasting of the transverse ridge are excluded for simplicity. Unmodified by mass wasting in the cartoon, the detachment fault footwall smoothly curves downward to the transform floor across the gabbro-mantle contact. It also extends downward from the inside-corner high to its termination on the rift valley floor. Thus, the detachment fault termination (heavy red, dashed line) extends along the foot of the rift valley wall, then curves, and progressively evolves from a normal fault, to oblique slip, to strike-slip at the base of the transform wall. The extension of the fault down below the transform valley (heavy red line) forms one branch of an active negative fault flower structure that forms the plate boundary between the African and Antarctic Plates

zone greatly reduced the shear strength and the effective normal stress on the nascent fault as well. With decreasing depth, sub-solidus crystal-plastic deformation occurred; replacing grain boundary sliding and diffusion creep in the partially molten gabbro. Here, dislocation creep and diffusion creep competed as deformation mechanisms, overprinting the hyper-solidus fabric. With increasing strain, deformation further localized to a relatively narrow zone of oxide gabbro mylonite (e.g., Fig. 36d) where diffusion creep likely predominated. As temperature and pressure dropped into the amphibolite facies with decreasing depth, deformation passed through the brittle-ductile transition, as shown by the presence of both crystal-plastically deformed amphibolites scattered around the bank (note the enclave of foliated amphibolite in Fig. 36b). Particularly noteworthy is the amphibole and plagioclase-cemented amphibolite mylonite breccia in Fig. 32d. As brittle conditions replaced ductile deformation, gabbro and diabase cataclasites formed prior to talc-serpentine intrusion on the fault plane. These are represented by both monomict (e.g., Fig. 36b) and polymict gabbro and diabase breccias. Finally, with intrusion of the talc-serpentine schist along the fault plane at relatively shallow depths in the brittle deformation zone, faulting localized into a narrow talc zone, only meters thick (e.g., Fig. 36b).

One unique feature of Atlantis Bank is a location where the detachment fault passed out of the gabbro into the mantle adjacent to the transform (e.g., Dive $6 \mathrm{~K}-459$ and Dredge 28). There, the detachment fault moved from gabbro-localized to peridotite-localized deformation, 


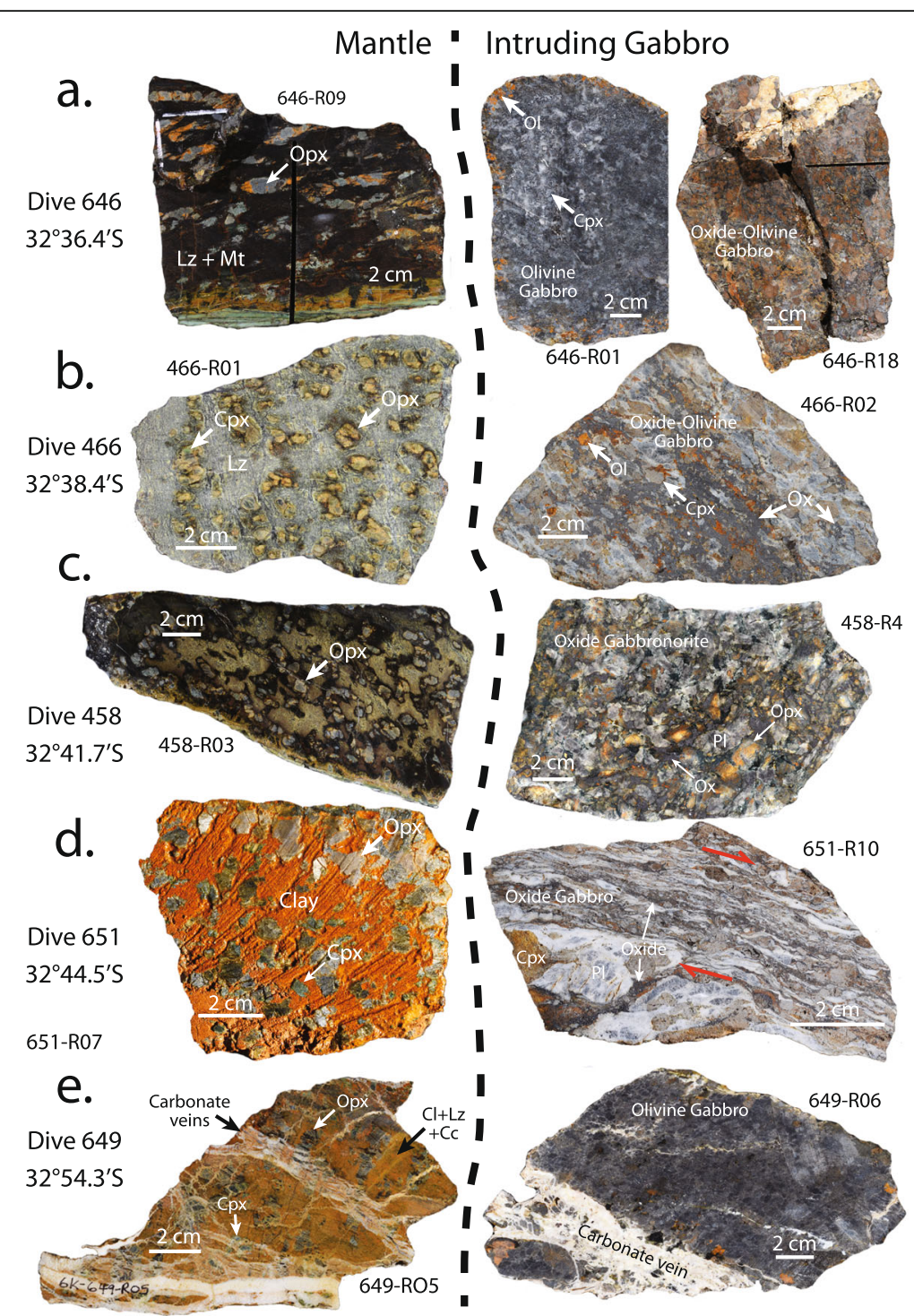

Fig. 49 Samples from directly above and below the gabbro-peridotite contact. a Weakly foliated porphyroclastic Iherzolite (C-P 1) and undeformed equigranular olivine and oxide gabbros. b Weakly foliated porphyroclastic Iherzolite (C-P 0.5) and weakly deformed (C-P 1) oxideolivine gabbro with a $4.5 \mathrm{~cm}$-wide oxide-rich band. c Weakly foliated porphyroclastic Iherzolite and an undeformed equigranular oxide-olivine gabbro. d Weathered, protogranular Iherzolite (C-P 0.25), and lightly deformed (C-P 0.75), pegmatoidal oxide-olivine gabbro with a $3.5 \mathrm{~cm}$-wide protomylonitic oxide-olivine gabbro band. e Weathered weakly foliated (C-P 1.5) Iherzolite with carbonate veins and an undeformed (C-P 0), equigranular olivine gabbro

resulting in a very different stress-strain history with melt absent, and localization of strain into high-temperature peridotite mylonites, terminated by the formation of talc schist (e.g., Fig. 48), as seen at the Abel mantle dome at the Kane Megamullion (Dick et al. 2008).

ODP and IODP drilling and our mapping show that magmatism waxed and waned through time with a corresponding advance or retreat of the brittle-ductile transition to different levels in the crust. This caused imbrication of the detachment fault, creating corresponding zones of enrichment in iron oxides and the formation of oxide gabbros in the shear zones at different levels in the upper kilometer of the lower crust, as well as vertical migration at the depth of diking, creating a relatively broad dike-gabbro transition (Fig. 49a).

At many detachment faults, as the fault locks, the zone of faulting jumps inward, often repeatedly, isolating shallow blocks capped by pillow lavas erupted in the rift valley on the older detachment fault footwall. However, the new fault often merges into the original fault at depth as it passes into the brittle-ductile transition, isolating a rider block of otherwise intact pillow lavas, dikes. and gabbro on the primary detachment footwall as at $16^{\circ} 30^{\prime}$ $\mathrm{N}$ on the Mid-Atlantic Ridge (e.g., Smith et al. 2014). 
The absence of such rider blocks at Atlantis Bank, however, is notable. We suggest that this reflects both a high stability of the master fault in the brittle regime, and a steeper slope at its termination at the rift valley floor compared to other plutonic growth faults.

\section{Oceanic core complexes form due to fault capture}

A major consideration in determining the geometry of the detachment fault is the enormous asymmetry in spreading rates during the emplacement of Atlantis Bank. Zircon age dating suggests that spreading may have been almost entirely to the south (Baines et al. 2008) coincident with a high rate of magmatic accretion on the growth fault, a combination that effectively eliminated tectonic extension across the rift valley and inward jumping of the brittle fault plane. The asymmetry in spreading of the plutonic section at oceanic core complexes, however, can only be explained by fault capture, as the detachment fault extends beneath the rift valley floor, blocking extension of the normal faults on the opposing wall, and capturing most of the zone of accretion as shown in Fig. 48. This, in fact, is reasonably the general case for asymmetric spreading at oceanic core complexes.

\section{Seismic implications of serpentine and talc}

Serpentine is commonly found as narrow sheets intruded between unrelated rocks in continental orogenic belts, most notably along the San Andreas Fault of California, where it has been linked to fault sections that show creep. Experimental studies suggest that serpentine intruded along faults might explain both aseismic slip and low shear strength (Reinen et al. 1994). However, the frictional strength of serpentine is too high to satisfy the limitations on fault strength for aseismic creep along the San Andreas Fault (Moore and Rymer 2007). Instead, the latter authors relate the aseismic creep to the presence of talc, as its frictional strength at elevated temperatures is sufficiently low to meet the conditions for aseismic creep. The abundance of talc in the serpentine fault gouge at Atlantis Bank, produced by alteration of enstatite, olivine, and serpentine, may thus result in aseismic slip on the plane of the principal detachment fault surface, masking its geometry. However, in an extensional rather than strike-slip environment, where the normal stress is reduced to the lithostatic or hydrostatic load, serpentinite may also serve this purpose. Thus, much of the seismic activity occurring beneath the detachment footwall at slow-spreading ridges is most likely internal to the core complex itself due to slab bending forces (e.g., Parnell-Turner et al. 2017) and do not constrain the active fault plane overlying the regions of seismic activity.

\section{Dike-gabbro transition}

There are numerous inliers of the dike-gabbro transition exposed over the Atlantis Bank Gabbro Massif, and in all cases the dikes cut the gabbros (e.g., Figs. 27 and 30). The gabbros associated with, and often in contact with, the dikes, at both the Kane Megamullion (Dick et al. 2008) and Atlantis Bank commonly exhibit substantial crystal-plastic deformation, for which there is very little evidence in any of the dikes. Thus, the dike-gabbro contact relations provide abundant evidence that the gabbros were intruded at depth and then emplaced mechanically upwards into the zone of dike intrusion (Fig. 48a). Clear chill zones and razor-sharp contacts are present in many samples intruded at lower temperatures, typically under greenschist facies conditions, but there are also undeformed, fine-grained dikes where the contact is sutured with coarser gabbro indicating slower cooling and magmatic interaction across the dike-gabbro interface. Local anatexis of the gabbros is found along some dike margins indicating that these dikes were intruded in the granulite facies $\left(\sim 700-800^{\circ} \mathrm{C}\right)$. In the higher-temperature intrusive suites, augite may be replaced by brown igneous amphibole near contacts and throughout thinner apophyses, in some cases forming oikocrysts enclosing plagioclase chadocrysts. Primary augite in the gabbro at the contact may also be partially replaced by brown hornblende.

In a large majority of dikes, the main alteration phase took place under lower amphibolite and greenschist facies conditions, although earlier overprinted hightemperature assemblages may be present. The latter reflects higher temperatures and deuteric alteration as the dike cooled down from its solidus to the ambient country rock temperature where the main phase of alteration occurred. Thus, we see a range of host-rock temperatures at the time of intrusion that extend from granulite facies $\left(\sim 800^{\circ} \mathrm{C}\right)$ down through lower greenschist facies. This likely reflects the depth range of intrusion, because dikes can rise a kilometer or more from their roots at the dike-gabbro transition, to their termination in the lavas.

On the basis of Hole 1473A stratigraphy and several Shinkai Dives (e.g., 6K-468), the dike-gabbro transition occurs over a broad zone, up to $\sim 400-500 \mathrm{~m}$, rather than at an abrupt transition over $\sim 100 \mathrm{~m}$ or less, with dikes giving way to gabbro with depth. Seven dikes were found at various depths down to $469 \mathrm{~m}$ in Hole 1473A, one at $25 \mathrm{~m}$ in Hole 735B, and none in Hole 1105a. Out of a total of $2.74 \mathrm{~km}$ of ODP and IODP cores, only 8 dikes were encountered, and none occur below the upper $500 \mathrm{~m}$. We relate the deeper dikes to the evidence for imbrication of the detachment fault root zone seen in the oxide gabbros in Hole 735B (Fig. 15), which indicates that the depth to the brittle-ductile transition 
varied by several hundred meters or more, and thus the depth to which diking occurred. One dike was also found intruded into talc-serpentine schist in the detachment footwall on the eastern side of the massif (e.g., Fig. 31a). A similar occurrence is also seen at the Kane Megamullion, where a $30 \mathrm{~cm}$ thick undeformed dike was imaged and sampled in a thick layer of talc-serpentine schist (Dick et al. 2008).

Thus, it is apparent that the detachment fault rooted through the base of the dike-gabbro transition in the active zone of diking. This places another major constraint on the geometry of the Atlantis Bank detachment fault, which must have passed through the transition, and into the underlying, still partially molten gabbro (Fig. 48a). Geometrically, this is very difficult if the fault dip rotates to near vertical. Given that the top of a partially molten gabbro body is a natural location for fault termination, it is very likely that during the main phase of accretion, the fault was listric and it crossed beneath the rift valley, assuming an overall ramp-flat-ramp morphology. In view of contrary evidence at smaller core complexes with low-melt flux, it is possible that the detachment fault would assume a more downward dip and termination in the absence of significant melt in the gabbros, or where it roots directly into the mantle.

\section{Dike-mantle transition zone}

Shinkai Dives 646 and 655 traversed a complex assemblage of partially serpentinized peridotite, gabbro and rodingitized gabbro, dikes, and talc-serpentine schist near the northern termination of the gabbro massif. This is best interpreted as a lateral transition across the dikegabbro transition into a dike-mantle transition, where magmatism had waned, and dikes intruded laterally down-axis into mantle rock near the transform fault (Fig. 21). Lavas fed by the dikes initially covered this transition but were removed by mass wasting that exposed the underlying magmatic plumbing system. A similar stratigraphy was also reported at the Kane Megamullion (Dick et al. 2008) and at $16^{\circ} 30^{\prime} \mathrm{N}$ on the MidAtlantic Ridge (Smith et al. 2014) where dikes were found cutting mantle peridotite between two unconnected magmatic centers.

\section{An intrusive contact between the gabbro massif and the mantle}

The contact between the gabbro massif and mantle peridotite was crossed seven times (Dives 174, 646, 649, 655, $466,458,651)$ on the eastern wall of the Atlantis II Transform. Despite an earlier report, the physical contact was not observed in situ but was constrained to within a few meters under a narrow carbonate-cemented rubble screen, originally mistaken for basement outcrop (Matsumoto et al. 2002), high on the transform wall at the southern end of the map area (Fig. 44). Excluding Dives 655 and 646, which crossed the boundary at the north end of the Atlantis Bank where magmatism had waned, the dive transects and dredge to the south provide a view of the mantle and crustal sections above, below, and beyond the contact during the main period of magmatic accretion.

The dives and RV Conrad Dredge 30 recovered 147 mantle rocks below the inferred contact: 90 spinel lherzolites, 9 harzburgites, 37 generic peridotites, 6 plagioclase lherzolites, 4 olivine websterites, and 1 dunite (Additional file 1: Table S1d). Although 12 of the peridotites have gabbroic veins ranging from $1 \mathrm{~mm}$ to $2.5 \mathrm{~cm}$, only 5 gabbros were found in the mantle section. Thus, we have a contact between massive mantle tectonite and massive gabbro, which is not the gabbro-peridotite contact envisaged in the Penrose Ophiolite model as seen at the Bay of Islands and Oman ophiolites.

Texturally, the peridotites are typical of large ophiolitic mantle massifs. Eighty of the peridotites have protogranular and 49 have porphyroclastic textures with an average crystal-plastic deformation grade of C-P $0.7 \pm 0.7$ $(1 \sigma, n=131)$. A single mylonite was found. The peridotites sampled closest to the contact are all protogranular or porphyroclastic tectonites (Fig. 49), whereas the gabbros are either undeformed or weakly deformed with only one protomylonite (Fig. 49d). Thus, the contact is sharp and intrusive, not tectonic.

The Atlantis II transform peridotites are some of the most fertile found on any ocean ridge; they have an average spinel $\mathrm{Cr} / \mathrm{Cr}+\mathrm{Al}$ (molecular) ratio of $18.3 \pm 4.0$, olivine of $\mathrm{Fo}_{90.1 \pm 0.2}$, diopside with $\mathrm{Mg} \#$ of $91.8 \pm 0.5$ and $6.0 \pm 0.8$ wt. $\% \mathrm{Al}_{2} \mathrm{O}_{3}$, and enstatite with $\mathrm{Mg} \#$ of $90.6 \pm$ 0.33 and $5.1 \pm 0.5$ wt.\% $\mathrm{Al}_{2} \mathrm{O}_{3}$ of (Johnson and Dick 1992). Despite this, none of the overlying gabbros are even close to equilibrium with a primary melt from this mantle having undergone a minimum of $50 \%$ fractional crystallization prior to intrusion.

From north to south the nature of the contact changes significantly from where Shinkai Dives 655 and 646 crossed from the dike-gabbro to dike-mantle transition. Shinkai Dives 466, 458, and 651 crossed the contact from massive granular peridotite into a section up to $2590 \mathrm{~m}$ thick of overlying massive gabbro exposed on the transform wall. An alternative explanation for the contact between the gabbro and the peridotite that it represents a simple north-south-striking, west-dipping, normal fault that juxtaposed underlying gabbros up against overlying peridotites seems improbable. If this were the case, there should be an extensive gabbro stockwork intruded into the overlying mantle section, which is totally missing in the hanging wall peridotites. Moreover, the textural evidence (Fig. 49) indicates an intrusive, not tectonic contact, with a near absence of 
gabbro and peridotite mylonites and cataclasites in samples from above and below. More likely, the transform wall is the eroded detachment fault footwall where it curves steeply down into the transform fault plane passing through the crust into the mantle. Viewed from the opposite perspective, the transform fault branches into a flower structure at the ridge-transform intersection where it curves into and merges with the transform fault zone (Fig. 48b). Subsequent erosion, mass wasting, and high-angle normal faulting on the transform wall then obscured a relationship between the transform fault zone and the detachment fault that is geometrically required.

Farther south, Kaiko Dive 10K-174 (Fig. 42) crossed from massive residual mantle peridotite exposed by mass wasting onto the edge of the western shelf where it sampled talcose peridotite corresponding to fault gouge of the detachment footwall assemblage. It is possible that the gabbro-mantle contact lies beneath this zone, but that cannot be determined from the available data as no gabbro was sampled with the metaperidotites. So it is more likely that this is simply the hydrated fault surface where it was rooted into mantle peridotite. However, Kaiko sample 10K173-21 sampled a rodingitized gabbro net vein complex downslope that would be the precursor to an intrusive body, which suggests that the contact here is laterally intrusive into the peridotite as shown in Fig. 43.

Finally, Shinkai Dive 6K-649 sampled and imaged the area of the gabbro-peridotite contact high on the wall of Atlantis Bank, where a small rubble screen, from which both peridotite and gabbro were sampled, covers it. Here, olivine gabbro was also recovered down slope $\sim 200 \mathrm{~m}$ from the contact, again suggesting a laterally intrusive contact between the gabbros and the mantle peridotite in the transform zone. Notably, there are no oxide-rich gabbros, as identified in hand sample or in thin section, which contrasts sharply with the other crossings of the contact where these are abundant. Nonetheless, all the gabbros are highly evolved, containing only

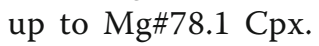

\section{Focused melt flow}

As will be discussed in the next section, it is clear from several lines of evidence that the Atlantis Bank Gabbro Massif is strongly zoned both vertically and laterally. However, additional evidence can also be seen from the occurrence of dunite and troctolite at Atlantis Bankboth are severely restricted in their occurrence, and both point to focused flow of melt out of the mantle towards the midpoint of the massif beneath the central paleo-rift valley.
Dunite was recovered at only three locations on the core complex. The deeply weathered, undeformed, pyroxenerich dunite found in Dredge JR31-6 (Fig. 33a) at the foot of the northeast-facing fault at $33^{\circ} 38^{\prime} \mathrm{S}$, and the talc-veined harzburgite recovered by Dive 644 from the eastern normal fault face (Fig. 33b) require a different source than the serpentinized peridotites scattered over the detachment fault. Given their isolated occurrence, they might be enclaves in serpentinite fault gouge, but in neither case is there any obvious connection to a fault cutting the transform, and they must be more locally derived close to the mid-point of the paleo-ridge segment. Their location far from the transform, and their absence in the transform wall dredges, is likely not coincidental. We sampled 103 peridotites at 10 locations below the gabbro-mantle contact on the transform wall, nearly all of which are statically serpentinized medium-to coarse-grained granular lherzolites-indicating that they had not been transported as serpentine intrusions along a fault zone, but were in situ or close to it. We found one undeformed dunite in situ on the transform wall, sample 6K-643-R15 (Fig. 33d), immediately below the elevated gabbro-peridotite contact explored by Dives 643 and 649 $12 \mathrm{~km}$ from the transform axis. Sample JR31-17-8 dredged high on the $57^{\circ} 18^{\prime} \mathrm{E}$ fault face consists of a harzburgite crosscut by a dunite, clearly representing a melt flow channel in mantle peridotite. This sample was collected with a suite of variably altered and weathered diabase and a bioclastic carbonate cemented diabase-serpentinite-soapstone breccia from $1320 \mathrm{~m}$ to the top of the fault scarp at 1000 $\mathrm{m}$. Thus it most likely represents an enclave of statically serpentinized peridotite from rubble sitting on the eroded edge of the detachment fault footwall $21 \mathrm{~km}$ from the transform.

These dunites may have formed by melt-rock reaction during melt transport through the shallow mantle (Dick 1977; Dick and Bullen 1984; Kelemen and Dick 1995; Quick 1981), as cumulates within, or at the base of, the lower crust (e.g., Boudier and Nicolas 1995), or by meltrock reaction during melt migration through rafted peridotite enclaves in the lower crust (Dick et al. 2008; Drouin et al. 2007; Drouin et al. 2009; Drouin et al. 2010; Sanfilippo et al. 2013; Suhr et al. 2008).

Troctolite is also highly restricted in occurrence at Atlantis Bank. Out of the 443 gabbros in the seafloor sample suite, one troctolite was identified. Troctolites were also found in 9 dike-like intervals between 425 and $497 \mathrm{~m}$ in Hole 735B in Unit VID (Dick et al. 1991a). With a total thickness of $5.61 \mathrm{~m}$, they comprise only $0.4 \%$ of the core, occurring in 9 intervals from 0.16 to $1.3 \mathrm{~m}$ thick as tabular or dike-like units of medium- to fine-grained, equigranular troctolite, with rare local chrome spinel layers and up to $\mathrm{Fo}_{88}$ olivine. They are part of a suite of microgabbros found throughout Hole $735 \mathrm{~B}$ that span nearly the full compositional range of 
the coarser olivine gabbro and oxide gabbros that they intrude. All of these microgabbros are interpreted as melt transport conduits; some representing channelized permeable flow and melt-rock reaction that modified the host rock, and others simple cumulates reflecting early crystallization of a parental MORB. What is clear, however, is that the scarcity of troctolites and the highly restricted occurrence of these and dunite in the central region of the gabbro massif, indicates that there was little primitive melt intruded or stored at shallow levels in the lower crust, and that melt transport through the lower crust to the overlying lavas was spatially severely restricted towards the center of the paleo-ridge segment.

\section{Compositionally zoned lower crust}

A major and unexpected discovery is that the Atlantis Bank Gabbro Massif is compositionally zoned both laterally and vertically. Rocks similar to the lower $1000 \mathrm{~m}$ of Hole $735 \mathrm{~B}$, drilled at the midpoint of the paleo-ridge segment, were not found at its distal portions in the northern, western, and southern sections. Missing are thick sequences of olivine gabbro, with little or no intervening oxide gabbros and primarily with magmatic rather than crystal-plastic textures, that occur in the lower $500 \mathrm{~m}$ of Hole 735B. Thus, there is an overall zonation of the gabbro massif, with more primitive gabbro occurring down section in the center of the body, and more evolved oxide gabbro intruded out to its ends. Moreover, gabbros at the gabbro-mantle contact are moderately to highly evolved, overlying mantle tectonites with no intervening dunite layer indicating that little or no melt was transported through the mantle to the crust in the vicinity of the transform.

None of the gabbros sampled thus far at Atlantis Bank, with the exception of the primitive troctolite dikes in the upper $500 \mathrm{~m}$ of Hole $735 \mathrm{~B}$ are close to equilibrium with mantle olivine, and hence, there is a large mass of primitive cumulates, dunites, and troctolites that must lie beneath the central section of the massif to mass balance the gabbros and overlying basalts and dikes back to a parental melt composition. There is considerable debate as to whether these crystallized in the shallow mantle or lie at the base of the gabbro massif. Both, of course, are possible; however, we find that the latter possibility is most attractive, both because there is little evidence for high-pressure crystallization in either the seafloor or drilled gabbros, but much to suggest crystallization at shallow depth extending up to where the detachment fault rooted in partially molten gabbro. This fits a model where mantle-derived magmas were emplaced at the segment centers and then intruded down-axis towards the transform even as they crystallized and fractionated. The evidence we have, albeit from the distal ends of the complex, supports this interpretation-but the only way to know for certain is to drill through the gabbro section at the center of the bank.

\section{Dynamic accretion}

The general consensus found in the ODP and IODP cruise reports and post-cruise publications is that the Atlantis Bank Gabbro Massif formed through numerous small nested intrusions, cross intruded by a wide variety of microgabbros formed both by focused reactive flow of melt through a permeable olivine gabbro matrix and by direct transport of melt through channels and dikes. In the $1508-\mathrm{m}$ Hole $735 \mathrm{~B}$, there is an overall strong upward enrichment in oxide gabbros through the section, with the lower most $300 \mathrm{~m}$ consisting entirely of olivine gabbro. Thus, following intrusion of individual olivine gabbro bodies, upward permeable flow of intercumulus melt due to compaction of the crystal matrix was a major process. This locally modified the olivine gabbros, hybridizing them to less-primitive compositions by melt-rock reaction. The melt being transported vertically, and laterally towards the transform was eventuallymodified by reaction to iron-titanium-rich liquids, characterized by excess incompatible element enrichment. These melts then localized into the detachment fault and its imbrications to produce often extreme local enrichment in oxides. It is yet to be determined if the several discrete zones of upward decrease in silicate Mg\# found in the ODP and IODP cores reflect repeated fractionation sequences in a series of separate intrusions, or if they represent compaction horizons where late fractionated melts pooled towards the top of each interval mimicking an upward enrichment trend. However, the excess oxide and incompatible element enrichment of these rocks favor the latter hypothesis.

\section{No melt lens}

A prominent feature of the Atlantis Bank Oceanic Core Complex is the abundance of dikes sampled by dredging and diving. This stands in stark contrast to the 7 dikes found in $2.5 \mathrm{~km}$ of drilling by ODP and IODP. Several inliers of what appear to be sheeted dikes were encountered, most notably during Dive 648 on the eastern wall of the complex. On the basis of fluid inclusion studies in the $735 \mathrm{~B}$ gabbros some 1.6 to $2.2 \mathrm{~km}$ of overburden was removed by detachment faulting during the emplacement of Atlantis Bank (Kelley and Früh-Green 2001; Schroeder and John 2004; Vanko and Stakes 1991). It is reasonable to assume, then, that the missing material represents a massive sheeted dike and lava complex consistent with the evident high magma flux and slowspreading rate at the time of formation of the gabbro massif.

There is no evidence for a melt lens at the base of massive sheeted dikes at Atlantis Bank, unlike the 
evolved gabbros immediately beneath the dikes at the East Pacific Rise (e.g., Koepke et al., 2008, France et al. 2009 Natland and Dick 2009; Wilson et al. 2006). In fact, unlike what is seen at the latter, where the gabbros cut and assimilate the dikes creating sharp contacts, the base of the sheeted dikes at Atlantis Bank is poorly defined, with the depth of diking evidently varying with time resulting in a section of massive dikes grading into intercalated dikes with gabbro screens, and then gabbro with occasional crosscutting dikes, and finally into massive gabbro without dikes. The Dive 648 section, for example, apparently varies from massive gabbro, or gabbro and rare dikes, at the base of the section up into sheeted dikes with subordinate gabbro screens over $\sim 500$ to $\mathrm{m}$ (Figs. 30 and 31). It is noteworthy that although diabase in contact with gabbro commonly has a chilled zone against the gabbro, some contacts are diffuse and may in fact show evidence of chemical interaction with the gabbro reflecting either vertical or lateral intrusion at depth through relatively hot host gabbros. At the same time, evidence from ophiolites (e.g., MacLeod and Rothery 1992) shows that the actual feeder zone for dikes is quite narrow and difficult to see, whereas dikes can extend many kilometers down-axis from the zone of intrusion above the brittle-ductile transition producing a relatively broad dike-gabbro transition zone. Although evidence for large-scale melt migration is abundant in the Atlantis Bank gabbros, the percentage of melt present at any one time was likely quite small, thus allowing transient brittle behavior during melt transport from low in the crust to the seafloor. Moreover, the root zone of a dike, even in the immediate zone of intrusion that passes through partially molten gabbro may effectively disappear at depth due to reequilibration with the adjacent wall rocks, which may be partially molten.

The internal stratigraphy of the Atlantis Bank Gabbro Massif sampled to date represents a dynamic evolution, with ongoing near-continuous crystal-plastic deformation driven by far-field forces that pulled the tectonic plates apart at the ridge axis (e.g., Cannat et al. 1991; Cannat et al. 1991b; Dick et al. 2017; Dick et al. 1991a; Dick et al. 2000; MacLeod et al. 2017a). Unlike a fast-spreading ridge, the melt supply cannot keep up with the spreading rate, and the lower crust can support a shear stress such that spreading occurs through both tectonic extension and magmatic accretion. With episodic intrusion, this created a complex stratigraphy at Atlantis Bank, unlike anything found in layered intrusions, though in the coarsest sense, the result is the same-a large body of gabbro that is both laterally and vertically zoned. There is little evidence for large-scale magmatic sedimentation and layering extending many kilometers through the massif. Most layering appears to be the product of internal deformation of a heterogeneous body that was crisscrossed by melt transport channels, with structurally controlled impregnation along shear zones, and stretching and extending of pegmatoidal patches and reaction channels in the gabbro that now mimic magmatic layering. There is no upward reversal of the stratigraphy, as in large layered intrusions corresponding to the roof of a large magma chamber or sandwich horizon.

This general sequence of magmatic evolution occurred while active hyper- and sub-solidus, crystal-plastic deformation was on-going, creating a great complexity of features that are often difficult to interpret. Hightemperature, crystal-plastic deformation is evident from numerous deformation twins in plagioclase and kinkbands in pyroxene, with more intense deformation creating masses of plagioclase and pyroxene neoblasts enclosing pyroxene and plagioclase augen. Grain-size reduction ranges from medium-grained in porphyroclastic rocks to very-fine-grained ultramylonitic textures (Fig. 4d). We use the term dynamic accretion to describe this process of on-going deformation, igneous intrusion and both distributed and focused permeable melt flow due to compaction. The resulting stratigraphy and structure reflect processes not found in traditional layered intrusions, but which are characteristic of a divergent plate boundary with low to intermediate rates of magmatic accretion versus tectonic extension. This contrasts sharply to what is known of the fast-spreading East Pacific Rise crust, which forms largely by passive magmatic accretion due to high melt flux (e.g., Natland and Dick 2001; Natland and Dick 2009).

At Atlantis Bank, it is clear from our results that the stratigraphy there represents a continuous process of dynamic accretion that produced an upper section of the lower crust immediately below the dike-gabbro transition enriched in oxide gabbros, with abundant evidence of hyper-solidus deformation, and permeable melt flow. Holes 735B, 1105A, and U1473A provide the key vertical dimension, and the similarity, to what has been found by seafloor sampling over the entire gabbro massif, shows that this tectono-magmatic stratigraphy is a basic characteristic of the entire massif.

\section{Summary and conclusions}

Shown in Fig. 50 is a geologic cross-section of Atlantis Bank, drawn through Site 735B that summarizes many of the insights drawn in the discussion section. For the most part, the surface geology in the figure, due to the excellent seafloor exposures, is real. However, the interpretation to the west of Shinkai Dive 6K-648 is speculative based only on seafloor morphology. It is likely the gabbro massif extends a bit farther west than is shown, but determining its full extent can only be done through seismic exploration. The Atlantis Bank Gabbro Massif represents the deep plumbing of a large oceanic 


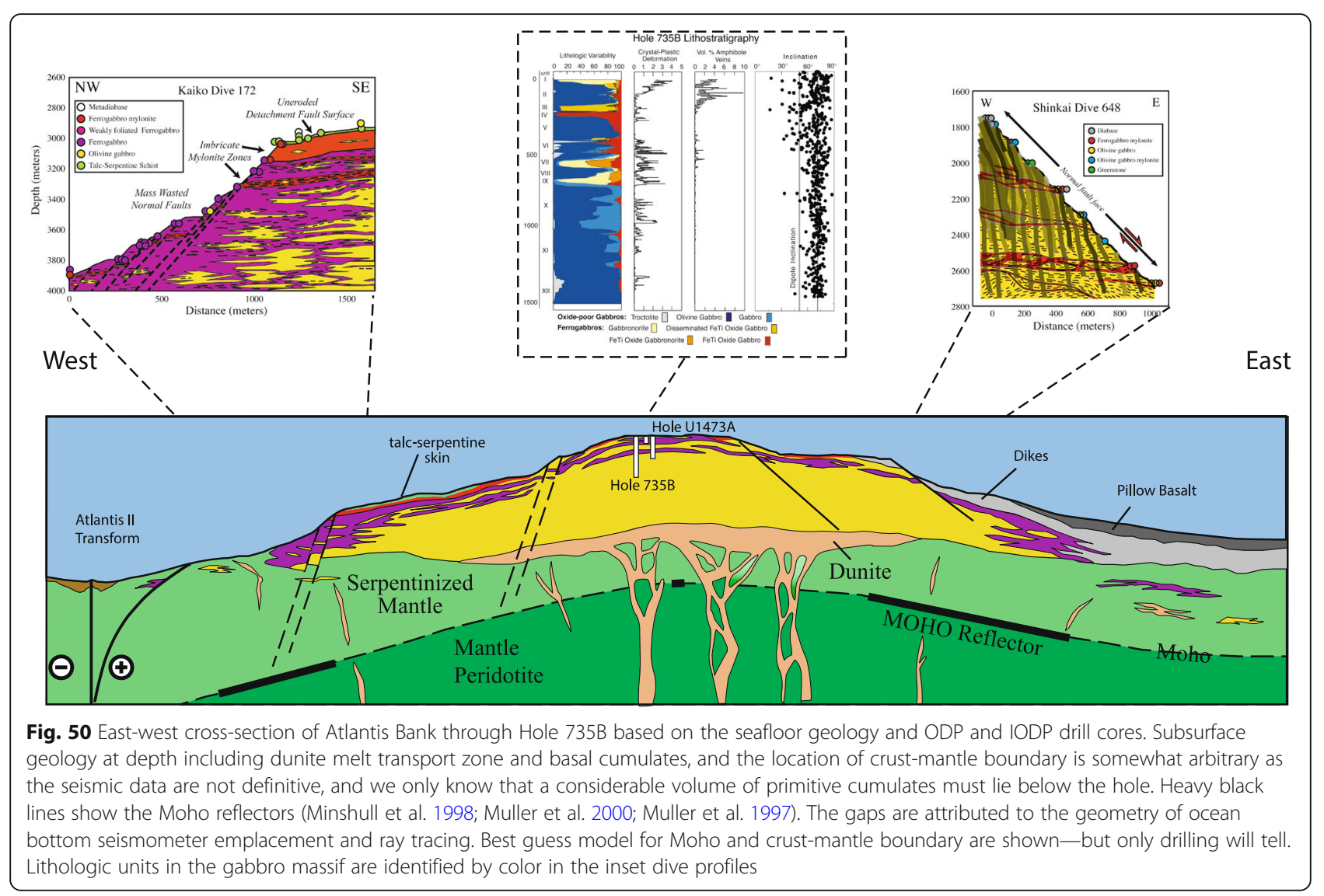

magmatic center formed at an ultraslow-spreading ridge. Including the pillow lavas and dikes, we can estimate that we are about 3-4 $\mathrm{km}$ down into the original crustal section. While we have no direct constraint on the total crustal thickness, given the missing primitive cumulates it must have be substantially thicker. Seismic surveys at the Mid-Atlantic Ridge and East Pacific Rise yield typical crustal thicknesses of $6-7 \mathrm{~km}$. Notably, the section at Atlantic Bank represents some of the thickest crust on the entire SWIR, which is otherwise likely thin and discontinuous (Dick and Zhou 2015; Zhou and Dick 2013). Nowhere else on the SWIR has gabbro been found as abundant.

The process by which the massif formed was by focused melt flow through the mantle to the middle of the magmatic complex. Intrusion was discontinuous, whereas deformation and extension, driven by far-field forces, was continuous. This produced an extraordinarily complex internal stratigraphy of nested intrusions, crosscutting melt transport channels, and continuous upward modifications in the stratigraphy by reactive porous flow. Critically, the lower crust could support a shear stress as shown by the mechanical transport and internal crystalplastic deformation whereby gabbros crystallized at depth were brought up to the zone of diking, such that the dikes studied to date always cut the gabbros. This is consistent with the rough topography of the SWIR and other slow-spreading ridges, with their enormous elastically supported topography-a feature missing at faster spreading ridges where the lower crust cannot support topography at the ridge axis.

The massif is both vertically and laterally zoned, with a sharp intrusive contact (at the resolution of the sampling intervals) with evolved gabbros intruded over massive, residual mantle tectonites on the transform wall. No evidence of wehrlite intrusions was found, which typify the lower crustal sequences in ophiolites thought to reflect supra-subduction zone environments. Because the rocks studied all represent at most the upper $1.5 \mathrm{~km}$ of the lower crust emplaced from the base of the paleorift valley wall, it is possible, that these may be found deeper in the section as late off-axis intrusions.

Another major difference from fast-spread ocean crust is that there is no evidence for a melt lens beneath the sheeted dikes, nor is this boundary sharp, rather it extends at least some $500 \mathrm{~m}$, reflecting variations in the depth to the brittle-ductile transition with the waxing and waning of magmatism. 
A major feature, also unexpected, is that the complex has an oxide gabbro cap of variable thickness that appears to have extended over the entire footwall of the detachment fault. This is prima facies evidence that the detachment fault rooted into partially molten gabbro beneath the dike-gabbro transition and suggests a ramp-flat-ramp geometry, encompassing the major portion of the zone of accretion beneath the rift valley. The detachment fault footwall also exposes a near-continuous talc-serpentine veneer over the oxide gabbro, which likely stabilized the detachment fault, allowing it to operate continuously for over 2,000,000 years. The fine-grained mylonites in the detachment footwall show that at depth strain was localized to a narrow zone, with diffusion and dislocation creep competing as the dominant deformation mechanism. Brittle diabase and gabbro cataclasites recovered from the fault damage zone show that in many cases, intrusion of the talc-serpentine schist occurred some distance above the brittle-ductile transition.

Nowhere did our survey cross the crust-mantle boundary, as we had previously assumed. Instead, considering the geochemistry, it has become obvious that the contact between the gabbro massif and the mantle traced along the wall of the transform is laterally intrusive. Unless the crust-mantle boundary here is coincident with the Moho observed by Muller et al. (2000), we have no direct constraint on its location, other than that it lies significantly deeper than the evolved gabbros drilled to $1508 \mathrm{~m}$ below the seafloor. This can only be determined by drilling, and Atlantis Bank is the only place in the oceans where this could be done with some confidence using existing technology.

\section{Supplementary information}

Supplementary information accompanies this paper at https://doi.org/10. 1186/s40645-019-0307-9.

Additional file 1. Sup Table 1a Dive locations. Sup Table 1b Dredge locations \& initial summaries. Sup Table 1c Dredge Summaries. Sup Table 1d sample description.

Additional file 2. Table S2. The samples analysed in this study (depths in centimeters).

Additional file 3. Sup Table 3A Plag. Sup Table 3B Cpx. Sup Table 3C Opx. Sup Table 3D OI.

Additional file 4. Supplemental Table IV. Augite Trace Element Compositions.

\section{Abbreviations}

Cpx: Clinopyroxene; SWIR: Southwest Indian Ridge

\section{Acknowledgements}

The authors are particularly indebted to the participation and contributions of Takeshi Matsumoto, JAMSTEC (Co-chief Scientist of Yokosuka cruise "ABCDE"); Barbara E. John, University of Wyoming; and Allegra Hosford, Woods Hole Oceanographic Institution, who participated in all three
JAMSTEC site survey cruises to Atlantis Bank. Also, to Simon Allerton, formerly of the University of Edinburgh who acted as a Co-Chief Scientist on James Clark Ross cruise JR31. Similarly, we are indebted to Sumio Miyashita, Niigata University; Jinichiro Maeda, Hokkaido University; Hidenori Kumagai, JAMSTEC; Greg Hirth, Woods Hole Oceanographic Institution; Lawrence Coogan, Cardiff University; and Michael Cheadle, University of Wyoming, all of who participated in two cruises. Not to be forgotten are the essential contributions of those who participated as scientists and watchstanders on one JAMSTEC cruises or James Clark Ross Cruise 31, Legs 1 and 2, including Toshitsugu Yamazaki, Geological Survey of Japan; Toru Yamasaki, Hokkaido University; Jessica Warren, Woods Hole Oceanographic Institution; Jiro Uesugi, Kanazawa University; Maurice A Tivey, Woods Hole Oceanographic Institution; Gary H Thompson, University of Hong Kong; Akira Takeuchi, Toyama University; Debra Stakes, MBARl; Hans Schouten, Woods Hole Oceanographic Institution; Eva Schandl, University of Toronto; Yukiko Ohtomo, Yamagata; James H Natland, Rosenstiel School of Oceanography; Tomoaki Morishita; Elena Miranda, University of Wyoming; Dhugal Lindsay, JAMSTEC; Eiichi Kikawa, JAMSTEC; Teruaki Ishii, ORI University of Tokyo; David Hutchinson, Cardiff University; Arlene G Hunter, Leeds University; Atsushi Hamadate, Kanazawa University; Allan Galley, Canadian Geological Survey; Stephen J Edwards, University of Greenwich; Graham Baines, University of Wyoming; Shoji Arai, Kanazawa University; Simon Allerton, Cardiff University; and Yoshio Adachi, Niigata University. HJBD is grateful to Linda Angeloni, Beecher Wooding, Benjamin Urann and Qiang Ma for assistance in working with the dredge and dive collections, as well as many fruitful discussions of the tectonics and petrogenesis of Atlantis Bank.

In addition, we wish to acknowledge Captain Ishida and the crews of the RV Kairei and Yokosuka, as well as the crew of the RV James Clark Ross, Keith Shepherd, and the ROPOS ROV Team, and the British Geologic Survey over-the-side Rock Drilling Team.

Mineral analyses were conducted with the assistance of Nilanjan Chatterjee at the electron microprobe laboratory at the Massachusetts Institute of Technology.

Frances Cooper and Alessio Sanfilippo provided helpful reviews that significantly improved the manuscript as did the editorial comments of Simon Wallis.

\section{Authors' contributions}

HJBD integrated AJSK's data and preliminary manuscript with the bathymetric, magnetics, and geologic sampling, analyzed the bathymetry and geology of Atlantis Bank and completed the geologic map of Atlantis Bank to produce this synthesis. AJSK with HJBD conceived the detailed gabbro mineralogy project as part of her PhD dissertation in the Woods Hole-MIT Joint Program in Marine Geology and Geophysics. She analyzed the mineralogy of the gabbros using the electron and ion microprobes, did the initial interpretation of the mineral data and geochemical modeling. She wrote a draft manuscript and drafted many of the figures for the mineral data. PTR analyzed the metamorphic petrology with $\mathrm{HJBD}$, assisted in drafting the initial geologic map with CJM and HJBD, and read and corrected the draft manuscript. CJM did the initial analysis of the exposed mineral and vein fabrics on the Atlantis Bank platform, as well as constructing an initial geologic map with HJBD of Atlantis Bank based on the dredge results. He also edited the initial manuscript. All authors read and approved the final manuscript. HK read and commented on the manuscript and its revisions. All authors have seen and approved the manuscript.

\section{Authors' information}

HJBD is a senior scientist in the Department of Geology and Geophysics at Woods Hole Oceanographic Institution. He was the lead proponent for ODP Legs 118 and 176, and for IODP Expedition 360 and served as Co-Chief Scientist of Leg 176 and Expedition 360. He is also the lead proponent for the SloMo Project (Drilling the Lower Crust and Moho at a Slow Spreading Ridge). He was Chief Scientist of RV Conrad cruise 27-09, co-lead proponent and Co-Chief Scientist for RSS James Clark Ross cruise JR31 Legs 1 and 2, and Co-Chief Scientist of JAMSTEC cruises RV Yokosuka MODE 98, RV Kaire MODE 2000, and RV Yokosuka cruise ABCDE. His specialties include field geology, tectonics, and igneous petrology at mid-ocean ridges. AJK is a professional geologist working at ReStone AS; was a watchstander on cruises James Clark Ross Cruise 31, Legs 1 and 2, and a diver on RV Yokosuka Cruise 
ABCDE; and was a watchstander on RV Kaire cruise MODE 2000. Her PhD dissertation was on the mineralogy of the Atlantis Bank gabbros. PTR is Professor Emeritus at Dalhousie University. He was Co-lead proponent and CoChief Scientist for James Clark Ross Cruise 31-Legs 1 and 2 a scientific diver on RV Yokosuka cruise MODE 1998, and Co-Chief Scientist of ODP Leg 118, and a metamorphic petrologist on ODP Leg 176. His research interests include ophiolites, metamorphic petrology and the evolution of the ocean crust. CJM is Professor of Geology in the School of Earth and Ocean Sciences at Cardiff University. He was lead proponent and Co-Chief Scientist of RRS James Clark Ross cruise JR31 Legs 1 and 2, proponent of the SloMo Project, and Co-Chief Scientist of IODP Expedition 360. He has broad expertise in structural geology, tectonics, petrology, geochemistry, and geophysics, applied both to modern ocean floor and to ophiolites. His principal scientific interests include investigating oceanic detachment fault mechanisms and the interactions between magmatic, tectonic, and hydrothermal processes at submarine volcanic spreading centers. HK was Co-Chief Scientist on RV Yokosuka cruise MODE 98 and lead proponent for all 3 RV Yokosuka and RV Kaire cruises. He is a marine geophysicist and former Associate Director of the Japanese Agency for Marine Science and Technology, Yokosuka, Japan.

\section{Funding}

Extensive ship time for the site surveys was provided by the Japan Agency for Marine-Earth Science and Technology. Funding for the ROV ROPOS was provided by the National Sciences and Engineering Council of Canada to PTR. Ship time, seabed rock drilling, and other operations during cruise JR31 were funded through UK Natural Environment Research Council awards GST/ 02/996 and GR3/10791 to CJM. The US National Science Foundation funded ship time and laboratory studies by grants $9618442,0426126,1434452$, and 8608143 to HJBD.

\section{Availability of data and materials}

All mineral major and trace element data are available through PetDB https://www.earthchem.org/petdb at Lamont-Doherty Earth Observatory. All rocks collected at Atlantis Bank, with the exception of the BGS rock drills, are available for sampling at the Woods Hole Oceanographic Institution Seafloor Samples Laboratory. The BGS rock drill cores are available through the School of Earth and Ocean Sciences of Cardiff University.

\section{Competing interests}

The authors declare that they have no competing interests.

\section{Author details}

${ }^{1}$ Woods Hole Oceanographic Institution, 266 Woods Hole Road, Woods Hole, Falmouth, MA 02543-1050, USA. ${ }^{2}$ ReStone AS, Vestlundveien 11 Fyllingsdalen, 5145 Bergen, Norway. ${ }^{3}$ Dalhousie University, Halifax, Nova Scotia, Canada. ${ }^{4}$ Cardiff University, Cardiff, Wales. ${ }^{5}$ Japan Agency for Marine-Earth Science and Technology, 2-15, Natsushima-cho, Yokosuka City, Kanagawa 237-0061, Japan.

Received: 5 June 2018 Revised: 22 August 2019

\section{Accepted: 9 September 2019 Published online: 14 November 2019}

\section{References}

Anders E, Grevesse N (1989) Abundances of the elements: meteoritic and solar. Geochim Cosmochim Acta 53:197-214

Anderson EM (1905) The dynamics of faulting. Trans Edinb Geol Soc 8:387-402

Arai S, Dick HJB, MODE 2000 Scientific Party (2001) Cruise Report MODE 2000 (Kairei/Kaiko KR00-06) investigation of Atlantis Bank and the SW Indian Ridge from $57^{\circ} \mathrm{E}$ to $62^{\circ} \mathrm{E}$. Japan Marine Science and Technology Center, Yokosuka, p 337

Armstrong JT (1995) Citzaf - a package of correction programs for the quantitative electron microbeam X-ray-analysis of thick polished materials, thin-films, and particles. Microbeam Anal 4:177-200

Bach W, Klein F (2009) The petrology of seafloor rodingites: insights from geochemical reaction path modeling. Lithos 112:103-117

Baines AG, Cheadle MJ, John BE, Schwartz JJ (2008) The rate of oceanic detachment faulting at Atlantis Bank, SW Indian Ridge. Earth Planet Sci Lett 273:105-114

Baines G, Cheadle MJ, Dick H, Hosford Scheirer A, John B, Kusznir N, Matsumoto $T$ (2003) Mechanism for generating the anomalous uplift of oceanic core complexes: Atlantis Bank, southwest Indian Ridge. Geology 31:1105-1108
Barnes SJ (1986) The effect of trapped liquid crystallization on cumulus mineral compositions in layered intrusions. Contrib Mineral Petrol 93:524-531

Blackman DK, Ildefonse B, John BE, Ohara Y, Miller DJ, MacLeod CJ, Scientists E (2006) Proceedings of the Integrated Ocean Drilling Program. Integrated Ocean Drilling Program Management International, College Station

Bonatti E, Ligi M, Brunelli D, Cipriani A, Fabretti P, Ferrante V, Gasperini L, Ottolini $L$ (2003) Mantle thermal pulses below the Mid-Atlantic Ridge and temporal variations in the formation of oceanic lithosphere. Nature 423:499-505

Boudier F, Nicolas A (1995) The nature of the Moho transition zone in the Oman ophiolite. J Petrol 36:777-796

Bowen NL, Schairer JF (1935) The system, MgO-FeO-SiO2. Am J Sci XXIX:151-217

Bowen NL, Tuttle OF (1949) The system MgO-SiO2-H2O. Bull Gelogical Soc Am 60:439-460

Cann JR, Blackman DK, Smith DK, McAllister E, Janssen B, Mello S, Avgerinos E, Pascoe AR, Escartin J (1997) Corrugated slip surfaces formed at ridgetransform intersections on the Mid-Atlantic Ridge. Nature 385:329-332

Cannat M (1991) Plastic deformation at an oceanic spreading ridge: a microstructural study of the site 735 gabbros (Southwest Indian Ocean). Proc ODP Sci Results 118:399-408

Cannat M, Casey JF (1995) An ultramafic lift at the Mid-Atlantic Ridge: successive stages of magmatism in serpentinized peridotites from the 15 degree $\mathrm{N}$ region. In: Vissers R, Nicolas A (eds) Mantle and lower crust exposed in oceanic ridges and in ophiolites. Kluwer, Norwell, pp 5-34

Cannat M, Mevel C, Stakes D (1991) Stretching of the deep crust at the slowspreading southwest Indian ridge. Tectonophysics 190:73-94

Cannat M, Mevel C, Stakes D (1991 b) Normal ductile shear zones at an oceanic spreading ridge: tectonic evolution of site 735 gabbros (Southwest Indian Ocean). In: Von Herzene RP a RPT (ed) Proceedings of the Ocean Drilling Program, scientific results. Ocean Drilling Program, College Station, pp 415-430

Cannat M, Rommevaux-Jestin C, Sauter D, Deplus C, Mendel V (1999) Formation of the axial relief at the very slow spreading Southwest Indian Ridge $\left(49^{\circ}\right.$ to 69E). J Geophys Res 104:22,825-822,843

Casey JF, Miller DJ (eds) (1999) Proceedings of the Ocean Drilling Program, initial results. Ocean Drilling Program, College Station

Casey JF, Miller DJ (eds) (2007) Proceedings of the Ocean Drilling Program, scientific results. Ocean Drilling Program, College Station

Conference Participants (1972) Penrose field conference: ophiolites. Geotimes 17:24-26

Coogan L, McCleod CJ, Dick HJB, Edwards SJ, Kvassnes A, Natland JH, Robinson PT, Thompson G, O'Hara MJ (2001) Whole rock geochemistry of gabbros from the Southwest Indian Ridge: constraints on geochemical fractionations between the upper and lower crust and magma chamber processes at (very) slow spreading ridges. Chem Geol 178:1-22

Dick HJB (1977) Evidence of partial melting in the Josephine Peridotite. In: Dick HJB (ed) Magma Genesis. Oregon Dept. of Geology and Mineral Industries, Portland, pp 59-62

Dick HJB (1989) Abyssal peridotites, very slow spreading ridges and ocean ridge magmatism. In: Saunders AD, Norry MJ (eds) Magmatism in the ocean basins, Geological Society Special Publication No. 42, pp 71-105

Dick HJB, Bryan WB, Thompson G (1981) Low-angle faulting and steady-state emplacement of plutonic rocks at ridge-transform intersections. EOS 62:406

Dick HJB, Bullen T (1984) Chromian spinel as a petrogenetic indicator in abyssal and alpine-type peridotites and spatially associated lavas. Contrib Mineral Petrol 86:54-76

Dick HJB, Lin J, Schouten H (2003) An ultraslow-spreading class of ocean ridge. Nature 426:405-412

Dick HJB, MacLeod CJ, Blum P (2015) Southwest Indian Ridge lower crust and moho: the nature of the lower crust and Moho at slower spreading ridges (SloMo-Leg 1). Int Ocean Discov Program Sci Prospectus 360:1-36

Dick HJB, MacLeod CJ, Blum P, Abe N, Blackman DK, Bowles JA, Cheadle MJ, Cho K, Ciazela J, Dean JR, Edgcomb VP, Ferrando C, France L, Ghosh B, Ildefonse BM, Kendrick MA, Koepke JH, Leong JAM, Liu C, Ma Q, Morishita T, Morris A, Natland JH, Nozaka T, Pluemper O, Sanfilippo A, Sylvan JB, Tivey MA, Tribuzio R, Viegas LGF (2017) Expedition 360 summary. In: MacLeod CJ, Dick HJB, Blum P (eds) Proceedings of the International Ocean Discovery Program. International Ocean Discovery Program, College Station, pp 1-27

Dick HJB, MacLeod CJ, Blum P, Scientists E (2016) Expedition 360 preliminary report Southwest Indian Ridge lower crust and Moho: the nature of the lower crust and Moho at slower spreading ridges (SloMo Leg 1). International Ocean Drilling Program, College Station, p 50

Dick HJB, Meyer PS, Bloomer S, Kirby S, Stakes D, Mawer C (1991a) Lithostratigraphic evolution of an in-situ section of oceanic layer 3. In: Robins 
PT, Von Herzen RP, Adamson AC, Becker K, Bloomer SH, Cannat M, Dick HJB, Emmermann RFK, Qard Q, David Goldberg D, Hebert R, Hertogen JQH, Hoskins H, Iturrino GJ, Kassenaar JDC, Kempton PD, Kikawa E, Kirby SH, Meyer PS, Natland JH, Ozawa K, Janet H, Pariso JH, Scott JH, Stakes DS, Stephen A (eds) Proceedings of the Ocean Drilling Program, scientific results. Ocean Drilling Program, College Station, pp 439-540

Dick HJB, Natland JH, Alt JC, Bach W, Bideau D, Gee JS, Haggas S, Hertogen JGH, Hirth G, Holm PM, Ildefonse B, Iturrino GJ, John BE, Kelley DS, Kikawa E, Kingdon A, LeRoux PJ, Maeda M, Meyer PS, Miller DJ, Naslund RH, Niu NY, Robinson PT, Snow J, Stephen RA, Trimby PW, Worm H, Yoshinobu A (1999) Site 735. Proceedings of the Ocean Drilling Program. Ocean Drilling Program, College Station, pp 1-314

Dick HJB, Natland JH, Alt JC, Bach W, Bideau D, Gee JS, Haggas S, Hertogen JGH, Hirth G, Holm PM, Ildefonse B, Iturrino GJ, John BE, Kelley DS, Kikawa E, Kingdon A, LeRoux PJ, Maeda M, Meyer PS, Miller DJ, Naslund RH, Niu NY, Robinson PT, Snow J, Stephen RA, Trimby PW, Worm H, Yoshinobu A (2000) A long in-situ section of the lower ocean crust: results of ODP leg 176 drilling at the Southwest Indian Ridge. Earth Planet Sci 179:31-51

Dick HJB, Natland JH, Ildefonse B (2006) Past and future impact of deep drilling in the oceanic crust and mantle. Oceanography 19:72-80

Dick HJB, Ozawa K, Meyer PS, Niu Y, Robinson PT, Constantin M, Hebert R, Maeda J, Natland JH, Hirth G, Mackie S (2002) Primary silicate mineral chemistry of a $1.5-\mathrm{km}$ section of very slow spreading lower ocean crust: ODP Hole 735B, Southwest Indian Ridge. In: Natland JH, Dick HJB, Miler DJ, Von Herzen R (eds) Proceedings of the Ocean Drilling Program, Scientific Results. Ocean Drilling Program, 1-60 [CD-ROM], College Station

Dick HJB, Robinson PT, Meyer PS (1992) The plutonic foundation of a slow-spreading ridge. In: Duncan RA, Al E (eds) Synthesis of Results from Scientific Drilling in the Indian Ocean: Geophysical Mon. 70: American Geophysical Union, pp 1-39

Dick HJB, Schouten H, Meyer PS, Gallo DG, Bergh H, Tyce R, Patriat P, Johnson KTM, Snow J, Fisher A (1991b) Tectonic evolution of the Atlantis II Fracture Zone. In: Robins PT, Von Herzen RP, Adamson AC, Becker K, Bloomer SH, Cannat M, Dick HJB, Emmermann RFK, Qard Q, David Goldberg D, Hebert R, Hertogen JQH, Hoskins H, Iturrino GJ, Kassenaar JDC, Kempton PD, Kikawa E, Kirby SH, Meyer PS, Natland JH, Ozawa K, Janet H, Pariso JH, Scott JH, Stakes DS, Stephen A (eds) Proceedings of the Ocean Drilling Program, Scientific Results. Ocean Drilling Program, College Station, pp 359-398

Dick HJB, Tivey MA, Tucholke BE (2008) Plutonic foundation of a slow-spreading ridge segment: oceanic core complex at Kane Megamullion, 23 degrees 30 ' N, 45 degrees 20 ' W. Geochem Geophys Geosyst 9,

Dick HJB, Zhou HY (2015) Ocean rises are products of variable mantle composition, temperature and focused melting. Nat Geosci 8:68-74

Drouin M, Godard M, Ildefonse B (2007) Origin of olivine-rich troctolites from IODP Hole U1309D in the Atlantis Massif (Mid-Atlantic Ridge): petrostructural and geochemical study. Eos Trans AGU 88(52):Abstract T53B-1300

Drouin M, Godard M, Ildefonse B, Bruguier O, Garrido CJ (2009) Geochemical and petrographic evidence for magmatic impregnation in the oceanic lithosphere at Atlantis massif, mid-Atlantic ridge (IODP Hole U1309D, 30N). Chem Geol 264:71-88

Drouin M, Ildefonse B, Godard M (2010) A microstructural imprint of melt impregnation in slow spreading lithosphere: olivine-rich troctolites from the Atlantis Massif, Mid-Atlantic Ridge, 30N, IODP Hole U1309D. Geochem Geophys Geosyst 4:71-88

Duncumb P, Reed SJB (1968) In: Heinrich, K. F. J. (ed.) Quantitative Electron Probe Microanalysis. National Bureau of Standards, Washington DC, pp 1-133

Elthon D, Casey JF, Komor S (1982) Mineral chemistry of ultramafic cumulates from the North Arm Massif of the Bay of Islands ophiolite: evidence for highpressure crystal fractionation of oceanic basalts. J Geophys Res 87:8717-8734

Engel CG, Fisher RL (1969) Lherzolite, anorthosite, gabbro, and basalt dredged from the mid-Indian Ocean Ridge. Science 166:1136-1141

Engel CG, Fisher RL (1975) Granitic to ultramafic rock complexes of the Indian Ocean ridge system, western Indian Ocean. Geol Soc Am Bull 86:1553-1578

Escartin J, Hirth G, Evans B (1997a) Effects of serpentinization on the lithospheric strength and the style of normal faulting at slow-spreading ridges. Earth Planet Sci Lett 151:181-189

Escartin J, Hirth G, Evans B (1997b) Nondilatant brittle deformation of serpentinites: implications for Mohr-Coulomb theory and the strength of faults. J Geophys Res 102:2897-2913

Escartin J, Smith DK, Cann JR, Schouten H, Langmuir CH, Escrig S (2008) Central role of detachment faults in accretion of slow-spreading oceanic lithosphere. Nature 455:790-794
Evans BW, Johannes W, Oterdoom H, Trommsdorff V (1976) Stability of chrysotile and antigorite in the serpentine multisystem. Schweiz Mineral Petrogr Mitt 56:79-93

Ghiorso MS, Sack RO (1995) Chemical mass-transfer in magmatic processes .4. A revised and internally consistent thermodynamic model for the interpolation and extrapolation of liquid-solid equilibria in magmatic systems at elevatedtemperatures and pressures. Contrib Mineral Petrol 119:197-212

Grove TL, Baker MB, Kinzler RJ (1984) Coupled CaAl-NaSi diffusion in plagioclase feldspar: experiments and applications to cooling rate speedometry. Geochim Cosmochim Acta 48:2113-2121

Grove TL, Kinzler RJ, Bryan WB (1992a) Fractionation of Mid-Ocean Ridge Basalt (MORB). Mantle Flow Melt Generation Mid-Ocean Ridges Geophysical Monograph 71:281-310

Grove TL, Kinzler RJ, Bryan WB (1992b) Fractionation of mid-ocean ridge basalts. Mantle flow and melt generation at mid-ocean ridges: American Geophysical Union, pp 281-310

Hosford A, Tivey M, Matsumoto T, Dick HJB, Schouten H, Kinoshita H (2003) Crustal magnetization and accretion at the Southwest Indian Ridge near the Atlantis II fracture zone, 0-25 Ma. J Geophys Res 108:EPM9-1-EPM9-23

Jaroslow GE, Hirth G, Dick HJB (1996) Abyssal peridotite mylonites: implications for grain-size sensitive flow and strain localization in the oceanic lithosphere. Tectonophysics 256:17-37

Johnson KTM, Dick HJB (1992) Open system melting and the temporal and spatial variation of peridotite and basalt compositions at the Atlantis II Fracture Zone. J Geophys Res 97:9219-9241

Kelemen PB, Dick HJB (1995) Focused melt flow and localized deformation in the upper mantle: juxtaposition of replacive dunite and ductile shear zones in the Josephine peridotite, SW Oregon. J Geophys Res 100:423-438

Kelley DS, Früh-Green G (2001) Volatile lines of descent in submarine plutonic environments: insights from stable isotopes and fluid inclusion analyses. Geochemica Cosmochimca Acta 65:3325-2246

Kinzler RJ, Grove TL (1993) Corrections and further discussion of the primary magmas of mid-ocean ridge basalts, 1 and 2. J Geophys Res 98:22,339-322,347

Kvassnes A (2004) The evolution of oceanic Gabbros: in-situ and ancient examples. Department of Geology and Geophysics. MIT - Woods Hole Joint Program in Oceanography, Woods Hole, p 250

Kvassnes AJS, Grove TL (2008) How partial melts of mafic lower crust affect ascending magmas at oceanic ridges. Contrib Mineral Petrol 156:49-71

Lindsley DH, Andersen DJ (1983) A two-pyroxene thermometer. J Geophys Res 88(Supplement):A887-A906

Lissenberg CJ, Dick HJB (2008) Melt-rock reaction in the lower ocean crust and its implications for the genesis of mid-ocean ridge basalt. Earth Planet Sci Lett 271:311-325

MacLeod CJ, Dick HJB, Blum P, Abe N, Blackman DK, Bowles JA, Cheadle MJ, Cho K, Ciazela J, Dean JR, Edgcomb VP, Ferrando C, France L, Ghosh B, Ildefonse BM, Kendrick MA, Koepke JH, Leong JAM, Liu C, Ma Q, Morishita T, Morris A, Natland JH, Nozaka T, Pluemper O, Sanfilippo A, Sylvan JB, Tivey MA, Tribuzio R, Viegas LGF (2017a) Site U1473. In: MacLeod CJ, Dick HJB, Blum P (eds) Proceedings of the International Ocean Discovery Program. International Ocean Discovery Program, College Station, pp 1-27

MacLeod CJ, Dick HJB, Blum P, Expedition-360-Scientists (2017b) Proceedings of the International Ocean Discovery Program. International Ocean Discovery Program, College Station

MacLeod CJ, Dick HJB, Blum P, Scientists E (2017c) Southwest Indian Ridge Lower Crust and Moho, Proceedings of the International Ocean Discovery Program. International Ocean Discovery Program, College Station

MacLeod CJ, Rothery DA (1992) Ridge axial segmentation in the Oman ophiolite: evidence from along-strike variations in the sheeted dyke complex, Ophiolites and their Modern Oceanic Analogues, pp 39-63

Matsumoto T, Dick HJ, Cruise A (2002) In-situ observation of the lower crust and upper mantle lithology in Atlantis Bank, SWIR - results from ABCDE Cruise, EOS, Transactions of the American Geophysical Union, p 83

Matsumoto T, Miyashita S, Arai S, Morishita T, Maeda J, Kumagai H, Ohtomo Y, Dick H (2003) Magmatism and "crust-mantle boundary" on the ultra-slow spreading ridge as observed in Atlantis Bank, Southwest Indian Ridge. J Geogr 112:705-719

McCollom TM, Klein F, Robbins M, Moskowitz B, Berquo TS, Jons N, Bach W, Templeton A (2016) Temperature trends for reaction rates, hydrogen generation, and partitioning of iron during experimental serpentinization of olivine. Geochim Cosmochim Acta 181:175-200

Mendel V, Sauter D, Parson L, Vanney JR (1997) Segmentation and morphotectonic variations along a super slow-spreading center: the 
Southwest Indian Ridge (57 degrees E-70 degrees E). Mar Geophys Res 19:505-533

Meyer PS, Dick HJB, Thompson G (1989) Cumulate gabbros from the Southwest Indian Ridge, $54^{\circ} \mathrm{S}-7^{\circ} 16^{\prime} \mathrm{E}$ : implications for magmatic processes at a slow spreading ridge. Contrib Mineral Petrol 103:44-63

Minshull TA, Muller MR, Robinson CJ, White RS, Bickle MJ (1998) Is the oceanic Moho a serpentinization front? Geol Soc Spec Publ 148:71-80

Miranda A, John BE (2010) Strain localization along the Atlantis Bank oceanic detachment fault system, Southwest Indian Ridge. Geochem Geophys Geosyst 11:1-33

Moore DE, Rymer MJ (2007) Talc-bearing serpentinite and the creeping section of the San Andreas fault. Nature 448:795-797

Muller MR, Minshull TA, White RS (2000) Crustal structure of the Southwest Indian Ridge at the Atlantis II fracture zone. J Geophys Res 105:25809-25828

Muller MR, Robinson CJ, Minshull TA, White RS, Bickle MJ (1997) Thin crust beneath ocean drilling program borehole $735 \mathrm{~B}$ at the Southwest Indian Ridge? Earth Planet Sci Lett 148:93-107

Natland JH, Dick HJB (2001) Formation of the lower ocean crust and the crystallization of gabbroic cumulates at a very slow spreading ridge. J Volcanol Geotherm Res 110:191-233

Natland JH, Dick HJB (2002) Stratigraphy and composition of gabbros drilled Ocean Drilling Program Hole 735B, Southwest Indian Ridge: A synthesis of geochemical data. In: Natland JH, Dick HJB, Miler DJ, Von Herzen R (eds) Proceedings of the Ocean Drilling Program, Scientific Results. Ocean Drilling Program, College Station, pp 1-69

Natland JH, Dick HJB (2009) Paired melt lenses at the East Pacific Rise and the pattern of melt flow through the gabbroic layer at a fast spreading ridge. Lithos 112:73-86

Natland JH, Dick HJB, Miller DJ, VonHerzen (2002) Proceedings of the Ocean Drilling Program, Scientific Results [CD-ROM]. Ocean Drilling Program, College Station

O'Hanley DS (1996) Serpentinites: records of tectonic and petrological history. Oxford University Press, New York

O'Hara MJ (1968) The bearing of phase equilibria studies in synthetic and natural systems on the origin and evolution of basic and ultrabasic rocks. Earth-Sci Rev 4:69-133

Pang KN, Li CS, Zhou MF, Ripley EM (2009) Mineral compositional constraints on petrogenesis and oxide ore genesis of the late Permian Panzhihua layered gabbroic intrusion, SW China. Lithos 110:199-214

Parnell-Turner R, Sohn RA, Peirce C, Reston TJ, MacLeod CI, Searle AC, Simao NM (2017) Oceanic detachment faults generate compression in extension. Geology 45:923

Platt JP, Behr WM, Cooper FJ (2015) Metamorphic core complexes: windows into the mechanics and rheology of the crust. J Geol Soc 172:9-27

Poliakov ANB, Buck WR (1998) Mechanics of stretching elastic-plastic-viscous layers: applications to slow-spreading mid-ocean ridges. In: Buck W, Delaney PT, Karson JA, Lagabrielle Y (eds) Faulting and magmatism at Mid-Ocean Ridges. American Geophysical Union, Washington, DC, pp 305-324

Presnall DC, Dixon SA, Dixon JR, O'Donnell TH, Brenner NL, Schrock RL, Dycus DW (1978) Liquidus phase relations on the join diopside-forsterite-anorthite from $1 \mathrm{~atm}$ to $20 \mathrm{kbar}$ : their bearing on the generation and crystallization of basaltic magma. Contrib Mineral Petrol 66:203-220

Quick JE (1981) The origin and significance of large, tabular dunite bodies in the Trinity Peridotite, Northern California. Contrib Mineral Petrol 78:413-422

Reinen LA, Weeks JD, Tullis TE (1994) The frictional behavior of Lizardite and antigorite serpentinites - experiments, constitutive models, and implications for natural faults. Pure Appl Geophys 143:317-358

Reston TJ, Weinrebe W, Grevemeyer I, Flueh ER, Mitchell NC, Kirstein L, Kopp C, Kopp H (2002) A rifted inside corner massif on the Mid-Atlantic Ridge at $5^{\circ} \mathrm{S}$. Earth Planet Sci Lett 200:255-269

Robinson CJ, Bickle MJ, Minshull TA, White RS, Nichols ARL (2001) Low degree melting under the Southwest Indian Ridge: the roles of mantle temperature, conductive cooling and wet melting. Earth Planet Sci Lett 188:383-398

Robinson PT, Dick HJB, Von Herzen RP (1991) Metamorphism and alteration in oceanic layer 3: Hole 735B. In: Robins PT, Von Herzen RP, Adamson AC, Becker K, Bloomer SH, Cannat M, Dick HJB, Emmermann RFK, Qard Q, Goldberg DDHR, Hertogen JQHHH, Iturrino GJ, Kassenaar JDC, Kempton PD, Kikawa E, Kirby SH, Meyer PS, Natland JH, Ozawa K, Pariso JH, Scott JH, Stakes DS, A., S (eds) Proceedings of the Ocean Drilling Program, scientific results. Ocean Drilling Program, College Station, pp 541-552

Robinson PT, Von Herzen R et al (1989) Proceedings of the Ocean Drilling Program, initial reports. Ocean Drilling Program, College Station

Sanfilippo A, Dick HJB, Ohara Y (2013) Melt-rock reaction in the mantle: mantle troctolitesfrom the Parece Vela ancient back-arc spreading center. J Petrol 54:855-861
Sauter D, Cannat M, Roumejon S, Andreani M, Birot D, Bronner A, Brunelli D, Carlut J, Delacour A, Guyader V, MacLeod CJ, Manatschal G, Mendel V, Menez B, Pasini V, Ruellan E, Searle R (2013) Continuous exhumation of mantle-derived rocks at the Southwest Indian Ridge for 11 million years. Nat Geosci 6:314-320

Schroeder T, John B, Frost BR (2002) Geologic implications of seawater circulation through peridotite exposed at slow-spreading mid-ocean ridges. Geology 30:367-370

Schroeder T, John BE (2004) Strain localization on an oceanic detachment fault system, Atlantis Massif, 30 degrees N, Mid-Atlantic Ridge. Geochem Geophys Geosyst 5, pp 30

Shipboard Scientific Party (1998) Site 732. In: Robinson, PT, Von Herzen RP, Adamson AC, Becker K, Bloomer SH, Cannat M, Dick HJB, Emmermann RFK, Qard Q, David Goldberg D, Hebert R, Hertogen JQH, Hoskins H, Iturrino GJ, Kassenaar JDC, Kempton PD, Kikawa E, Kirby SH, Meyer PS, Natland JH, Ozawa K, Janet H, Pariso $J$, Scott JH, Stakes DS, Stephen A (eds) Proceedings of the Ocean Drilling Program. Ocean Drilling Program, College Station, pp 41-57

Shimizu N, Hart SR (1982) Applications of the ion microprobe to geochemistry and cosmochemistry. Annu Rev Earth Planet Sci 10:483-526

Smith DK, Escartin J, Schouten H, Cann JR (2008) Fault rotation and core complex formation: significant processes in seafloor formation at slow-spreading midocean ridges (Mid-Atlantic Ridge, 13 degrees-15 degrees N). Geochem Geophys Geosyst 9, pp 23

Smith DK, Schouten H, Dick HJB, Cann JR, Salters V, Marschall HR, Ji FW, Yoerger D, Sanfilippo A, Parnell-Turner R, Palmiotto C, Zheleznov A, Bai HL, Junkin W, Urann B, Dick S, Sulanowska M, Lemmond P, Curry S (2014) Development and evolution of detachment faulting along $50 \mathrm{~km}$ of the Mid-Atlantic Ridge near 16.5 degrees N. Geochem Geophys Geosyst 15:4692-4711

Snow JE (1993) The isotope geochemistry of abyssal peridotites and related rocks, MIT/Woods Hole Joint Program in Marine Geology and Geophysics. Woods Hole Oceanographic Institution/Massachusetts Institute of Technology, Woods Hole

Stakes D, Mével C, Cannat M, Chaput T (1991) Metamorphic stratigraphy of hole 735B. In: Von Herzen RP a RPT (ed) Proceedings of the Ocean Drilling Program, Scientific Results. Ocean Drilling Program, College Station, pp 153-180

Suhr G, Hellebrand E, Johnson K, Brunelli D (2008) Stacked gabbro units and intervening mantle: A detailed look at a section of IODP Leg 305, Hole U1309D. Geochem Geophys Geosyst 9:31

Tucholke BE, Behn MD, Buck R, Lin J (2008) The role of melt supply in oceanic detachment faulting and formation of megamullions. Geology 36:455-458

Tucholke BE, Lin J (1994) A geological model for the structure of ridge segments in slow spreading ocean crust. J Geophys Res 99:11937-11958

Vanko DA, Stakes DS (1991) Fluids in oceanic Layer 3: evidence from veined rocks, Hole 735B, Southwest Indian Ridge. Proc ODP Sci Results 118:181-215

White RS, McKenzie D, O'Nions RK (1992) Oceanic crustal thickness from seismic measurements and rare earth element inversions. J Geophys Res 97:19683-19715

Whitehead JA Jr, Dick HJB, Schouten H (1984) A mechanism for magmatic accretion under spreading centres. Nature 312:146-148

Whitney DL, Teyssier C, Rey P, Buck WR (2013) Continental and oceanic core complexes. Geol Soc Am Bull 125:273-298

Wilson DS, Teagle DA, Alt JC, Banerjee NR, Umino S, Miyashita S, Acton GD, Anma R, Barr SR, Belghoul A, Carlut J, Christie DM, Coggon RM, Cooper KM, Cordier C, Crispini L, Durand SR, Einaudi F, Galli L, Gao Y, Geldmacher J, Gilbert L, Hayman NW, Herrero-Bervera E, Hirano N, Holter S, Ingle S, Jiang S, Kalberkamp U, Kerneklian M, Koepke J, Laverne C, Vasquez LL, MacLennan J, Morgan S, Neo N, Nichols HJ, Park S, Reichow MK, Sakuyama T, Sano T, Sandwell R, Scheibner B, Smith-Duque CE, Swift S, Tartarotti P, Tikku AA, Tominaga M, Veloso EA, Yamasaki T, Yamazaki S, Ziegler C (2006) Drilling to gabbro in intact ocean crust. Science 312:1016-1020

Workman RK, Hart SR (2005) Major and trace element composition of the depleted MORB mantle (DMM). Earth Planet Sci Lett 231:53-72

Yund RA, Snow E (1989) Effects of hydrogen fugacity and confining pressure on the interdiffusion rate of NaSi-CaAl in plagioclase. J Geophys Res 94: $10,662-610,668$

Zhou H-Y, Dick HJB (2013) Thin crust as evidence for depleted mantle supporting the Marion Rise. Nature 494:195-200

Zindler A, Hart S (1986) Chemical geodynamics. Annu Rev Earth Planet Sci 14:493-571

\section{Publisher's Note}

Springer Nature remains neutral with regard to jurisdictional claims in published maps and institutional affiliations. 